
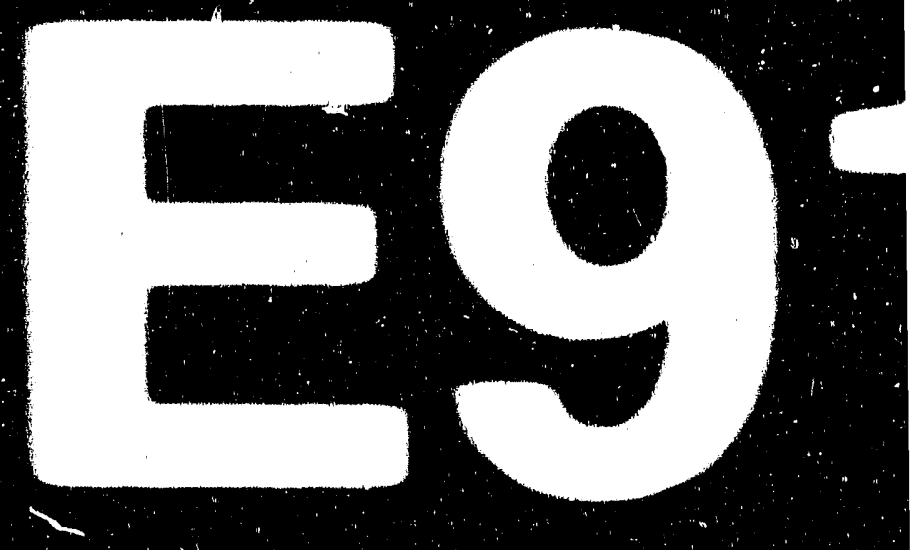

D
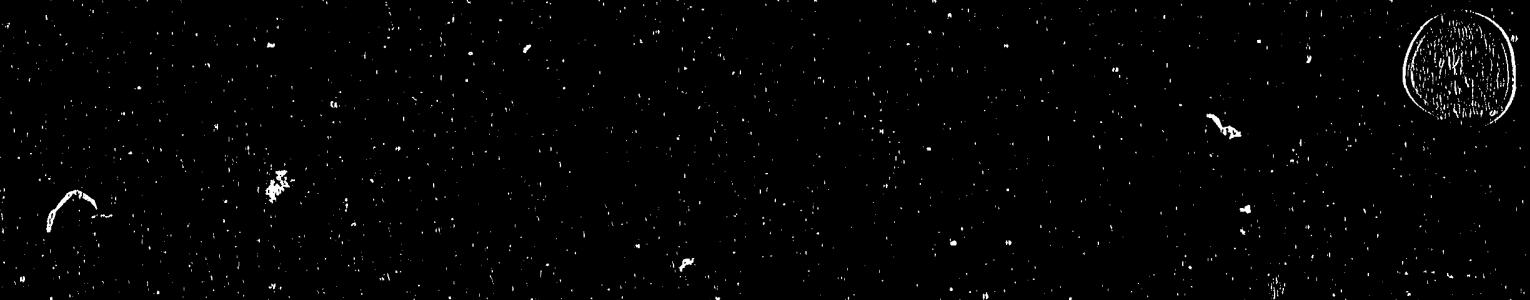

sio

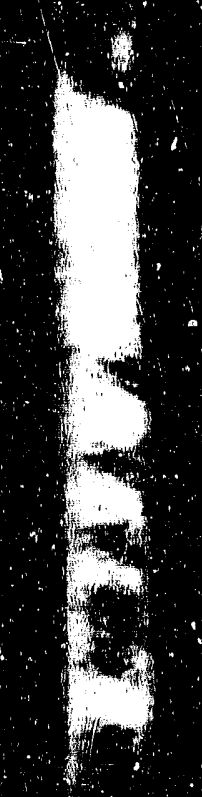

7

;

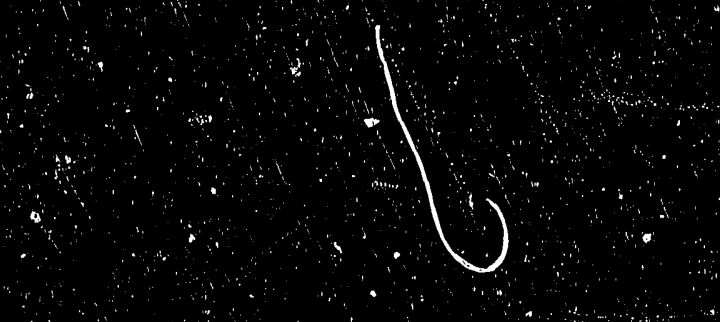

- 1
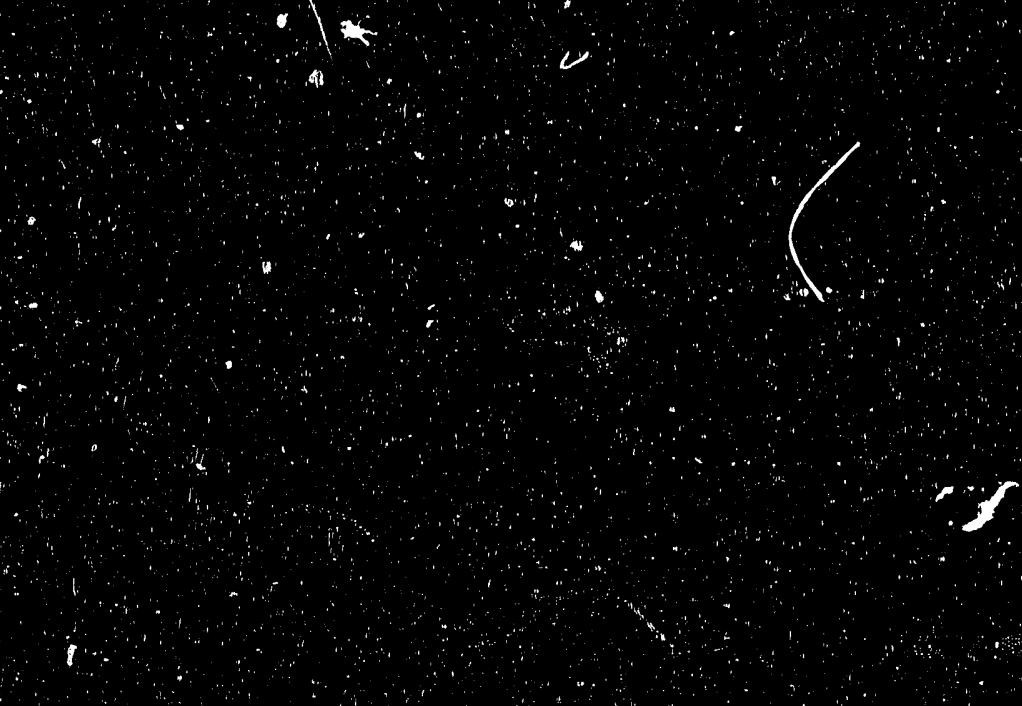


\section{Hydrological Conditions at the 317/319 Area at Argonne National Laboratory}

by T.L. Patton, R.H. Pearl, ${ }^{*}$ and S.Y. Tsai*

Environmental Assessment and Information Sciences Division,

Argonne National Laboratory, 9700 South Cass Avenue, Argonne, Illinois 60439

August 1990

Work sponsored by Environment, Safety, and Health Department, Support Services Division, Argonne National Laboratory

*Pearl is currently employed by Eder Associates, Madison, Wisconsin, and Tsai by International Technology Corporation, Irvine, California. 


\section{CONTENTS}

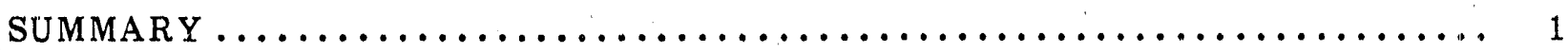

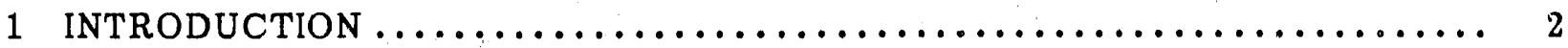

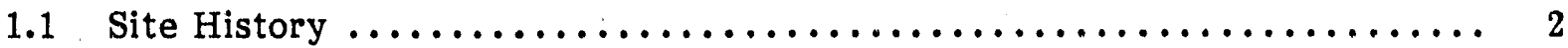

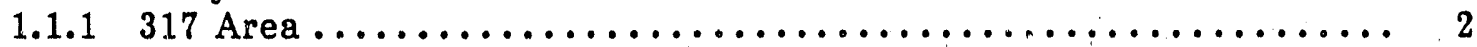

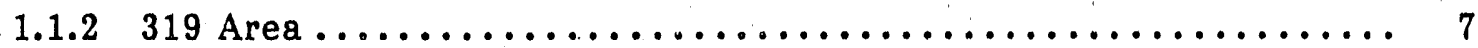

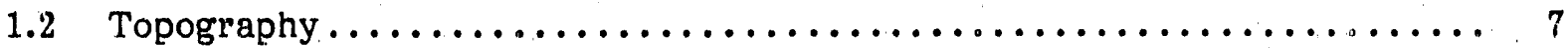

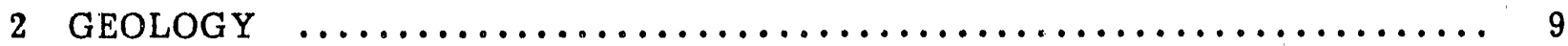

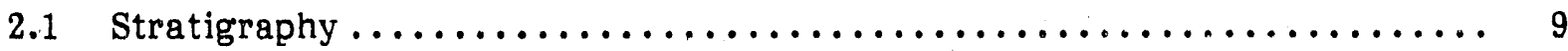

2.1.1 Bedrock Geology .............................. 9

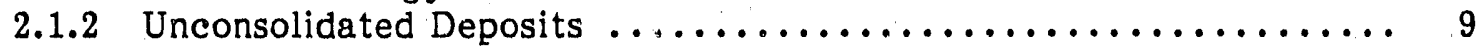

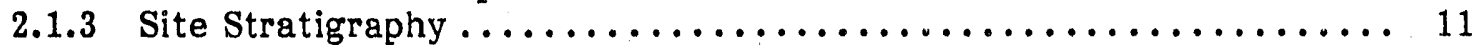

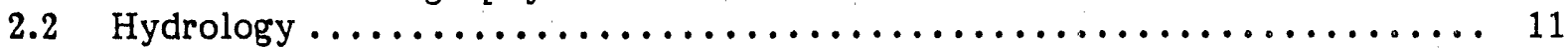

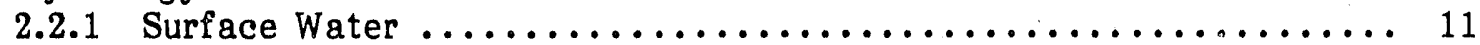

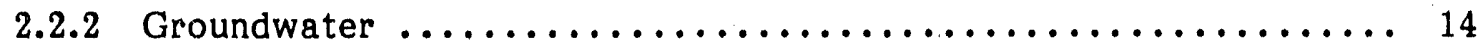

2.2.3 Contaminant Migration Potential ..................... 14

3 GROUNDWATER CONDITIONS AT THE $317 / 319$ AREA $\ldots \ldots \ldots \ldots \ldots \ldots \ldots$

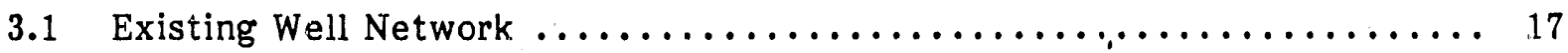

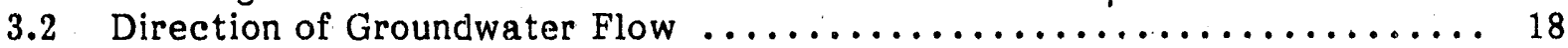

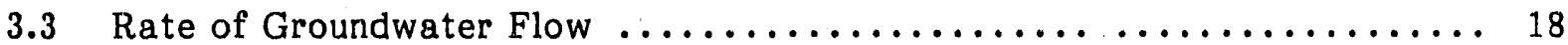

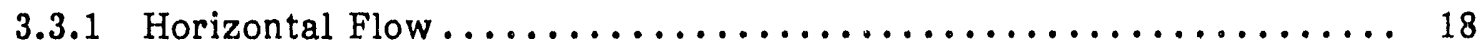

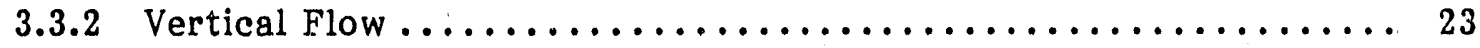

3.4 Groundwater Level Fluctuations .......................... 23

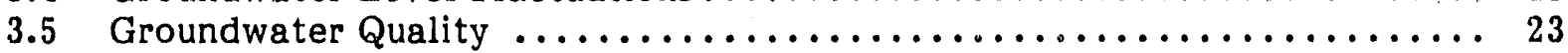

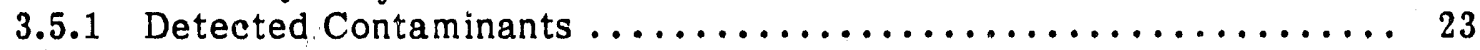

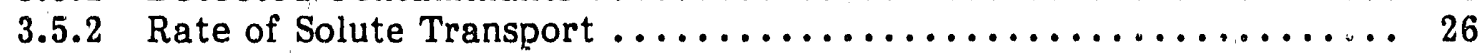

4 CONCLUSIONS AND RECOMMENDATIONS FOR FURTHER STUDY . . . . . 27

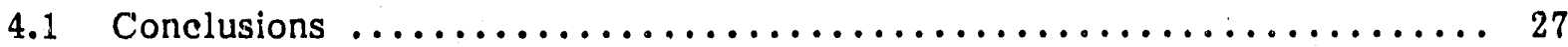

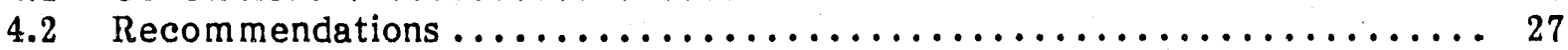

4.2.1 Definition of Subsurface Geology .................... 27

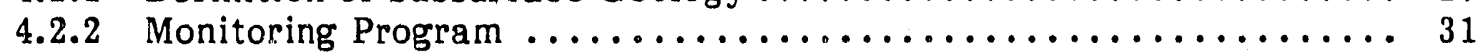

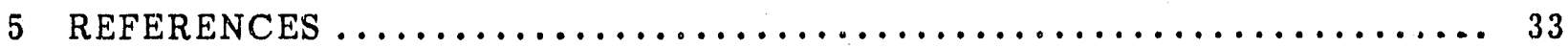

APPENDIX A: Available Well Installation Diagrams, Drillers' Logs, and Geologists' Logs for Borings in the $317 / 319$ Area .......... 35

APPENDIX B: Static Water Levels Measured in Monitoring Wells Since 1986 


\section{CONTENTS (Cont'd)}

APPENDIX C: Draft Groundwater Monitoring Network Guidance from the Illinois Environmental Protection Agency, Division of

Land Pollution Control ......................... 75

APPENDIX D: Monitoring Well Design and Construction Recommendations of the U.S. Environmental Protection Agency .............. 85

\section{TABLES}

1 Approximate Dimensions of Burial Vaults at the $317 / 319$ Area .......... 6

2 Summary of the Design and Construction of Monitoring Wells

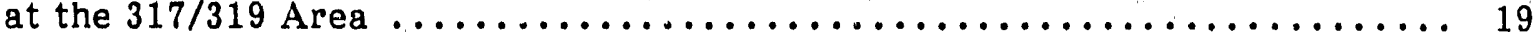

3 Weli Point and Water Elevations of Monitoring Wells Completed in the Till at the $317 / 319$ Area, $1988-1989 \ldots \ldots \ldots \ldots \ldots \ldots \ldots \ldots \ldots \ldots \ldots$

4 Concentrations of Inorganic Analytes in Samples from Monitoring Wells at the $317 / 319$ Area, $1988 \ldots \ldots \ldots \ldots \ldots \ldots \ldots \ldots \ldots \ldots \ldots \ldots \ldots \ldots$

5 Concentrations of Organic Analytes in Samples from Monitoring

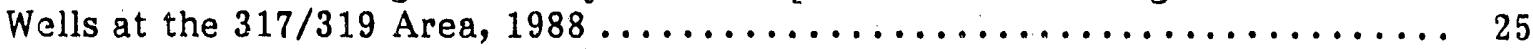

6 Information That Should Be Logged in the Field during the Drilling of Well Bores . ............................. 28

A.1 Boring Diagrams and Logs Presented in Áppendix A $\ldots \ldots \ldots \ldots \ldots \ldots \ldots$

B.1 Well Point and Water Elevations of Monitoring Wells at

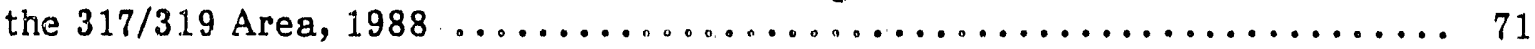

B.2 Well Point and Water Elevations of Monitoring Wells at

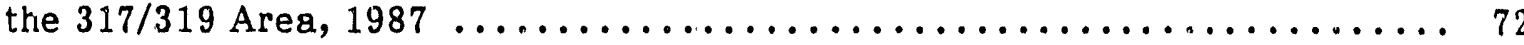

B.3 Well Point and Water Elevations of Monitoring Wells at

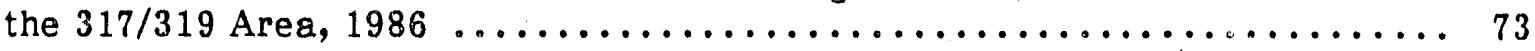

C.1 Illinois EPA Procedures for Plugging Monitoring Wells ............. 76

C.2 Routine and Background Analytic Parameters for Groundwater

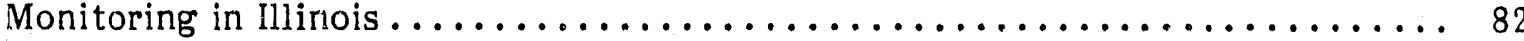




\section{FIGURES}

1 Location of Argonne National Laboratory, DuPage County,

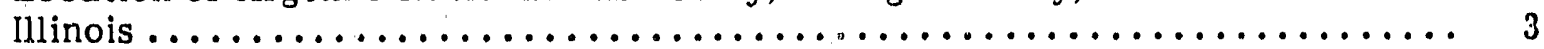

2 Map of Argonne National Laboratory Showing the Location

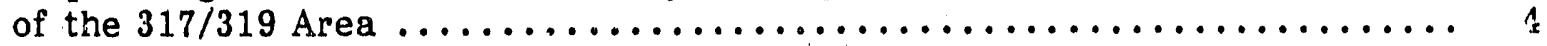

3 Locations of Burial Vaults, Manholes, French Drains, Monitoring

Wells, and Subsurface Cross Sections at the $317 / 319$ Area ............ 5

4 Topography of the $317 / 319$ Area $\ldots \ldots \ldots \ldots \ldots \ldots \ldots \ldots \ldots \ldots \ldots \ldots \ldots$

5 Stratigraphy and Geohydrology of DuFage County $\ldots \ldots \ldots \ldots \ldots \ldots \ldots$

6 Geologic Cross Section $A-A^{\prime} \ldots \ldots \ldots \ldots \ldots \ldots \ldots \ldots \ldots \ldots \ldots \ldots \ldots \ldots \ldots$

7 Geologic Cross Section $B-B^{\prime} \ldots \ldots \ldots \ldots \ldots \ldots \ldots \ldots \ldots \ldots \ldots \ldots \ldots \ldots$

8 Approximate Elevation of the Niagaran Dolomite Bedrock Surface

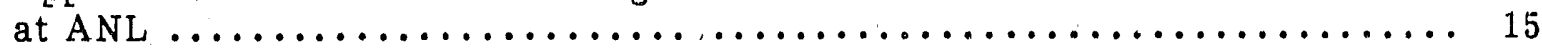

9 Piezometric Surface of Groundwater in the Niagaran Dolomite

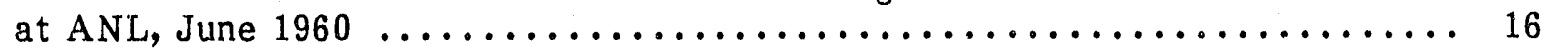

10 Schematic Diagram of Well Point Elevations and Monitoring Intervals for All Monitoring Wells Completed in the Till at the $317 / 319$ Area ....... 20

11 Groundwater Elevations at the $317 / 319$ Area, May $1989 \ldots \ldots \ldots \ldots \ldots \ldots$

12 Groundwater Elevations for Monitoring Wells Completed in the Till,

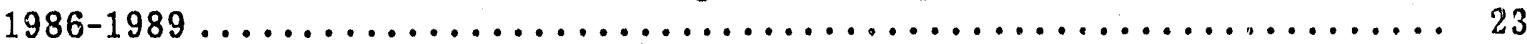

13 Locations of Proposed Monitoring Wells at the $317 / 319$ Area ........... 30

C.1 Diagram of a Monitoring Well for a State-Permitted Facility .......... 79

C.2 Example of an Illinois Well Completion Report $\ldots \ldots \ldots \ldots \ldots \ldots \ldots \ldots \ldots$ 


\title{
HYDROLOGICAL CONDITIONS AT THE 317/319 AREA AT ARGONNE NATIONAL LABORATORY
}

\author{
by \\ T.L. Patton, R.H. Pearl, and S.Y. Tsai
}

\section{SUMMARY}

This study examined the hydrological conditions of the glacial till underlying the 317/319 Area at Argonne National Laboratory (ANL) near Lemont, Illinois. The study's purpose was to review and summarize hydrological data collected by ANL's Environmení, Safety, and Health. Department and to characterize, based on these data, the groundwater movement and migration of potential contaminants in the area. Recommendations for further study have been made based on the findings of this review.

The 317/31.9 Area is located between Meridian Road and the southern border of ANL. The 317 Area was commissioned in the late 1940 s for the temporary storage of radioactive waste. Low- and high-level solid radioactive waste is stored in partially buried concrete vaults. Low-level radioactive waste awaiting shipment for off-site disposal is stored in aboveground steel bins north of the vaults. The 319 Area is an inactive landfill, located east of the 317 Area that was used for the disposal of general refuse, demolition debris, and laboratory equipment. Fluorescent light bulbs, chemical containers, and suspect waste were also placed in the landfill. Liquid chemical wastes were disposed of at each site in gravel-filled trenches called "French drains."

The $317 / 319$ Area is underlain by a silty clay glacial till. Dolomite bedrock underlies the till at an average depth of about $19.5 \mathrm{~m}(64 \mathrm{ft})$. Organic contaminants and radionuclides have been detected in groundwater samples from wells completed in the till. Fractures in the clay as well as sand and gravel lenses present in the till could permit these contaminants to migrate downward to the dolomite aquifer. At the time of this report, no chemical quality analyses had been made on grourdwater samples from the dolomite.

Water levels measured in monitoring wells completed in the till indicate that the predominant direction of groundwater flow is to the southeast. The horizontal groundwater velocity was estimated to range from 17 to $58 \mathrm{~cm} / \mathrm{yr}$. Water levels in the dolomite wells were not available when this report was prepared.

The study found that existing information about subsurface characteristics at the site is inadequate to identify potential pathways for contaminant migration. Recommended actions include installation of eight new well clusters and three background wells, thorough record-keeping, sample collection and analysis during borehole drilling, slug testing to measure hydraulic conductivity, continued monitoring of groundwater levels and quality, and monitoring of the unsaturated zone. 


\section{INTRODUCTION}

This report presents the results of a study of the hydrogeology of the glacial till underlying the 317/319 Area at Argonne National Laboratory (ANL) near Lemont, Illinois. The study was conducted by the Environmental Assessment and Information Sciences Division at the request of the Environment, Safety, and Health Department (ESH) of ANL's Support Services Division. The study's objective is to characterize movement of groundwater and potential contaminants based on a review of data collected by ESH. This report presents a summary of the groundwater monitoring program through the second quarter of 1989. Recommendations for further study nave been made on the basis of this review.

This section briefly describes the history and physical sstting of the 317/319 Area, Sec. 2 describes the area's geology and hydrology, Sec. 3 reviews previous groundwater monitoring activities at the site, and Sec. 4 recommends actions to acquire additional data. Supplemental information is provided in the appendixes: App. A provides records of well installation and logging, App. B contains water levels measured in the wells since 1986, App. C summarizes draft groundwater monitoring guidance from the Illinois Environmental Protection Agency (Illinois EPA), and App. D summarizes the monitoring well design and construction practices recommended by the U.S. Environmental Protection Agency (U.S. EPA).

\subsection{SITE HISTORY}

Figure 1 shows the location of ANL, which is in T37N, R11E, Sections 3, 4, 8, 9, 10, 15, 16, and 17, DuPage County, Illinois. The 317/319 Area (Section 16) is located just south of Meridian Road on the southern border of ANL (Fig. 2).

\subsubsection{Area}

The 317 Area is a fenced area about $151.6 \mathrm{~m}(497.5 \mathrm{ft})$ by $201.2 \mathrm{~m}(660 \mathrm{ft})$. The area was commissioned in the late 1940 s for the temporary storage of radioactive waste. Radioactive waste is stored in partially buried concrete vaults that were constructed in the early 1950 s in parallel east-west rows (Fig. 3). The tops of the vaults extend about $0.9 \mathrm{~m}(3 \mathrm{ft})$ above the land surface. The northern row consists of three separate vaults: the north vault to the west, the map tube facility in the center, and the deep vault to the east. The southern row also contains three vaults. The vault dimensions are given in Table 1. Most of the vaults are used to store containers of intermediate- and low-level solid radioactive waste. The map tube facility stores small containers of highly radioactive waste. North of the vaults is a gravelled area used for the aboveground storage of steel bins containing low-level radioactive waste awaiting shipment for off-site disposal (Moos 1990).

An interior drainage system was built into the vaults to collect and dispose of water entering the vaults through leaks in the concrete walls. Water is channeled into a series of sumps and, before 1987, was drained to off-site outfalls through an underground 


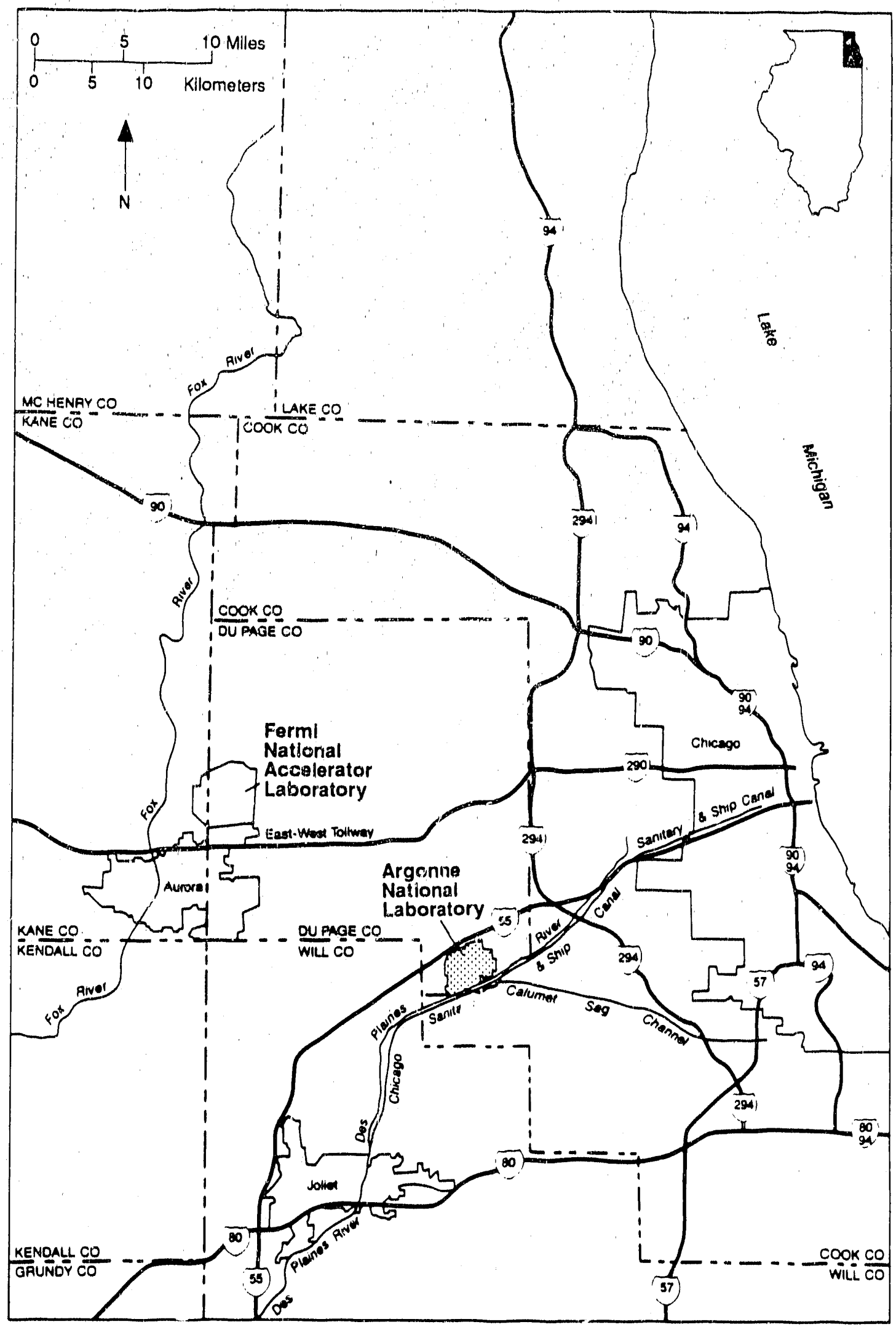

FIGURE 1 Location of Argonne National Laboratory, DuPage County, minois (Source: Modified from Killey and Trask 1989) 


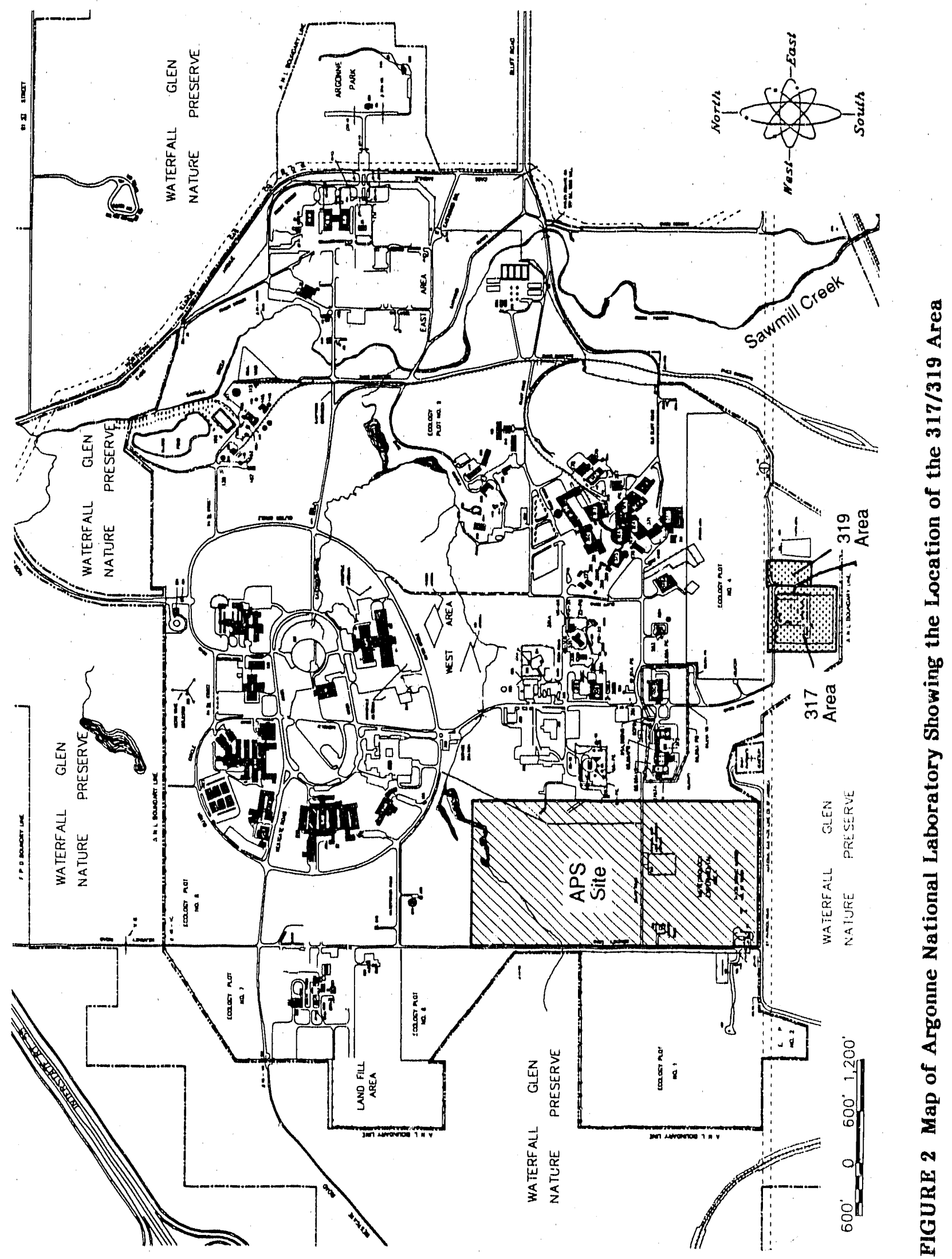




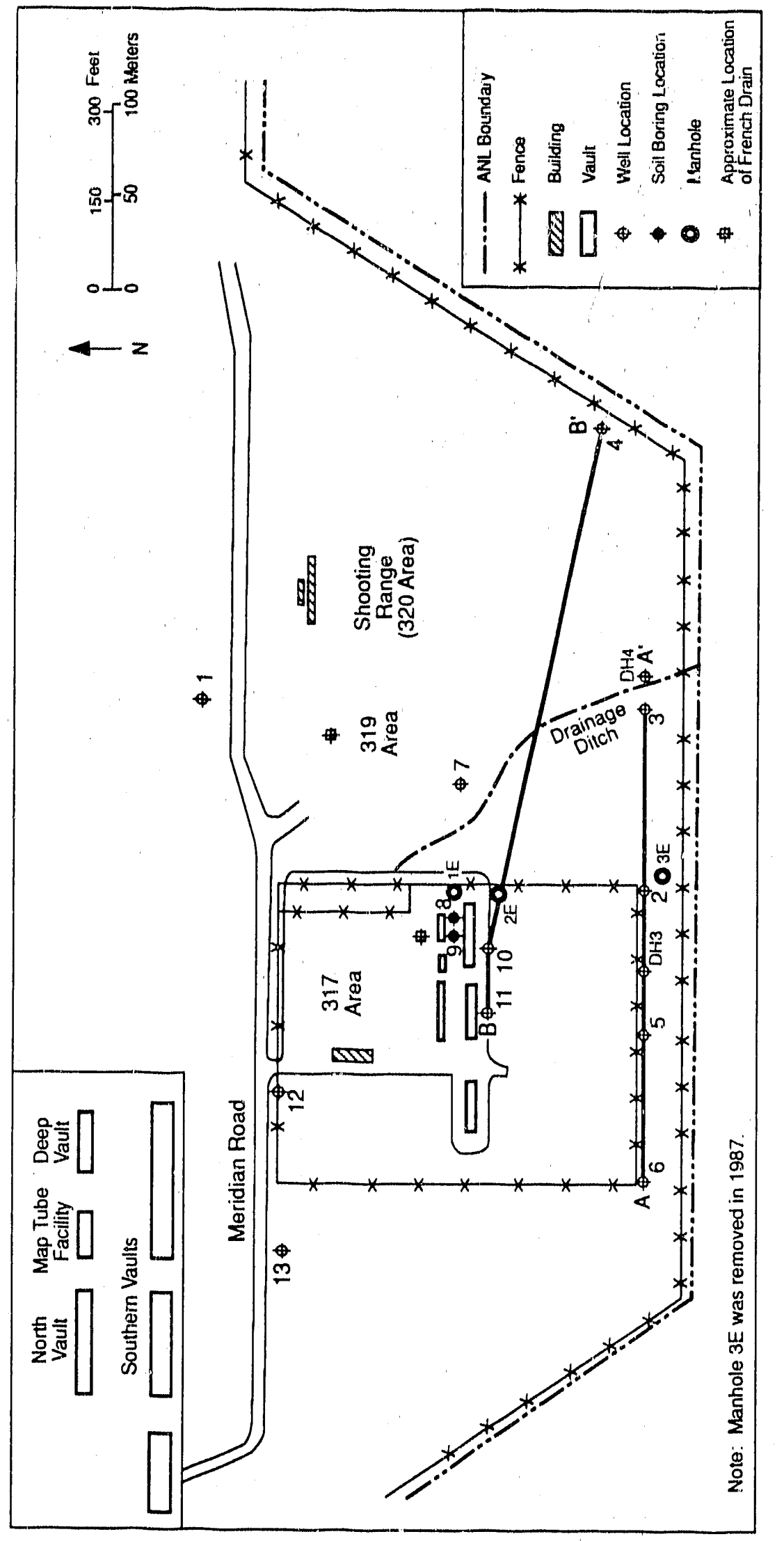

总

o

巳

紐

先

$\frac{5}{0}$

焉

苟

$>$

跑

엉

号

赵

s.

象

怘 
TABLE 1 Approximate Dimensions of Burial Vaults at the $317 / 319$ Area

\begin{tabular}{|c|c|c|c|c|c|c|}
\hline \multirow[b]{2}{*}{ Vault } & \multicolumn{2}{|c|}{ Length } & \multicolumn{2}{|c|}{ Width } & \multicolumn{2}{|c|}{ Depth } \\
\hline & $\mathrm{m}$ & $\mathrm{Et}$ & in & ft & $\mathrm{m}$ & $\mathrm{ft}$ \\
\hline North vault & 30 & 100 & 5 & 15 & 3 & 10 \\
\hline Map tube facility & 9 & 30 & 5 & 15 & 6 & 20 \\
\hline Deep vault & 12 & 40 & 5 & 15 & 6.4 & 21 \\
\hline Southern vaults & 30 & 100 & 5 & 15 & 3 & 10 \\
\hline
\end{tabular}

sewer system. Footing drains placed around the exteriors of the map tube facility and deep vault also drain water into the sewer system. The northern vaults drain into manhole $1 \mathrm{E}$, and the southern vaults drain into manhole $2 \mathrm{E}$ (Fig. 3 ). Water from manhole $1 \mathrm{E}$ flows to manhole $2 \mathrm{E}$. From these manholes, water then flowed through manhole 3E (Fig. 3) to an outfall that is now located on Waterfall Glen Forest Preserve property (ANL owned this property until 1973). Flow to this outfall was stopped in 1987 by the physical removal of manhole $3 \mathrm{E}$ and by the cutting and plugging of the sewer line about $150 \mathrm{ft}$ south of manhole $2 \mathrm{E}$ (Moos 1990).

Currently, about $15,140 \mathrm{~L}(4,000 \mathrm{gal})$ of water is collected in manhole $2 \mathrm{E}$ each week. On an as-needed basis, about two or three times per week, ANL Waste Management Operations staff pump the water out of manhole $2 \mathrm{E}$ into a tanker truck. The water is then taken to Building 306 where it is tested for radioactivity before being discharged to the laboratory sewer system. Laboratory sewer effluent discharges into Sawmill Creek (Cheever 1988).

There are two RCRA-permitted facilities used to treat small amounts of hazardous nonradioactive waste within the 317 Area. The first, known as the "shoot and burn pile," is located southeast of the southwest vault. At this unit, containers of explosives or unstable wastes are placed on a 5-ft tall pile of sand and detonated, usually by rifle fire, and allowed to react. The residue is collected and disposed of off site. The second unit consists of a water reaction tank (built into the southwest vault) used to react alicali metals (Moos 1990 ).

During the early 1950s, a gravel-filled trench about 3-4 ft deep and 100-150 ft long was used to dispose of nonradioactive liquid chemical waste. Figure 3 shows the estimated location of the trench; its location is not apparent from current surface features in the area. The trench, known as a "French drain," was used for 4 or 5 years. Use of the trench was discontinued when a new French drain was constructed in the 319 Area (discussed in the following section). To date, no records describing the nature of the wastes poured into the French drain have been located. Waste Management personnel have said that a wide variety of wastes were probably disposed of in the drain, 
including aromatic and aliphatic hydrocarbons, waste oils (possibly polychlorinated biphenyl [PCB] oils), halogenated hydrocarbons, and various solvents and heavy metals (Moos 1990).

\subsubsection{Area}

The 319 Area, about $122 \mathrm{~m}(400 \mathrm{ft})$ by $201 \mathrm{~m}(660 \mathrm{ft})$, is located east of the 317 Area (Fig. 3). It is an inactive landfill that was operated from the mid-1950s to 1968 and used for the disposal of general refuse, demolition debris, and laboratory equipmient. Fluorescent light bulbs, chemical containers, and suspect waste* were also placed in the landfill. The landfill consists of as many as six trenches $10-15 \mathrm{ft}$ deep. After the trenches were filled, waste was accumulated in piles above grade, creating the mound observed in the northern portion of the site. In the late 1950s or early 1960s, a French drain was constructed into the fill materials in the northern area of the mound. The drain consisted of a gravel bed, possibly 6-8 $\mathrm{ft}$ below grade. A corrugated steel pipe was placed vertically onto the gravel bed and backfilled. A pit surrounding the pipe was created by using railroad ties. Liquid chemical wastes were poured into the pit until the landfill at the 800 Area, also containing a French drain, was constructed in 1966. To date, no records describing the wastes poured into the French drain have been located. It is likely that the drain received solvents, degreasirig sol tions, cleaning solutions, and waste olls (Moos 1990).

\subsection{TOPOGRAPHY}

The major topographic feature of the region is the Des Plaines River valley. The Des Plaines River, located about $914 \mathrm{~m}(3,000 \mathrm{ft})$ south of A.NL (Fig. 1), has an elevation of $183 \mathrm{~m}(600 \mathrm{ft}$ ) above mean sea level (MSL), about $23 \mathrm{~m}$ (77 ft) below that at the $317 / 319$ Area.

Figure 4 shows the topography of the 317/319 Area. The 317 Area surface gently slopes from the northwest, where the elevation is $211.5 \mathrm{~m}(694 \mathrm{ft})$ above MSL, to the southeast, where the elevation is about $206.4 \mathrm{~m}(677 \mathrm{ft})$. In the 319 Area, the northern portion contains a mound with an elevation of $213.7 \mathrm{~m}(701 \mathrm{ft})$ above MSL. The elevation decreases to $203.6 \mathrm{~m}(688 \mathrm{ft})$ at the southernmost portion of this area.

\footnotetext{
*Suspect waste is from areas where radioactive material was used and for which radioactive contamination is suspected but not verified. For example, small pipes were considered suspect due to possible exposure of their interiors to radioactive material although, due to their configuration, it could not be verified.
} 


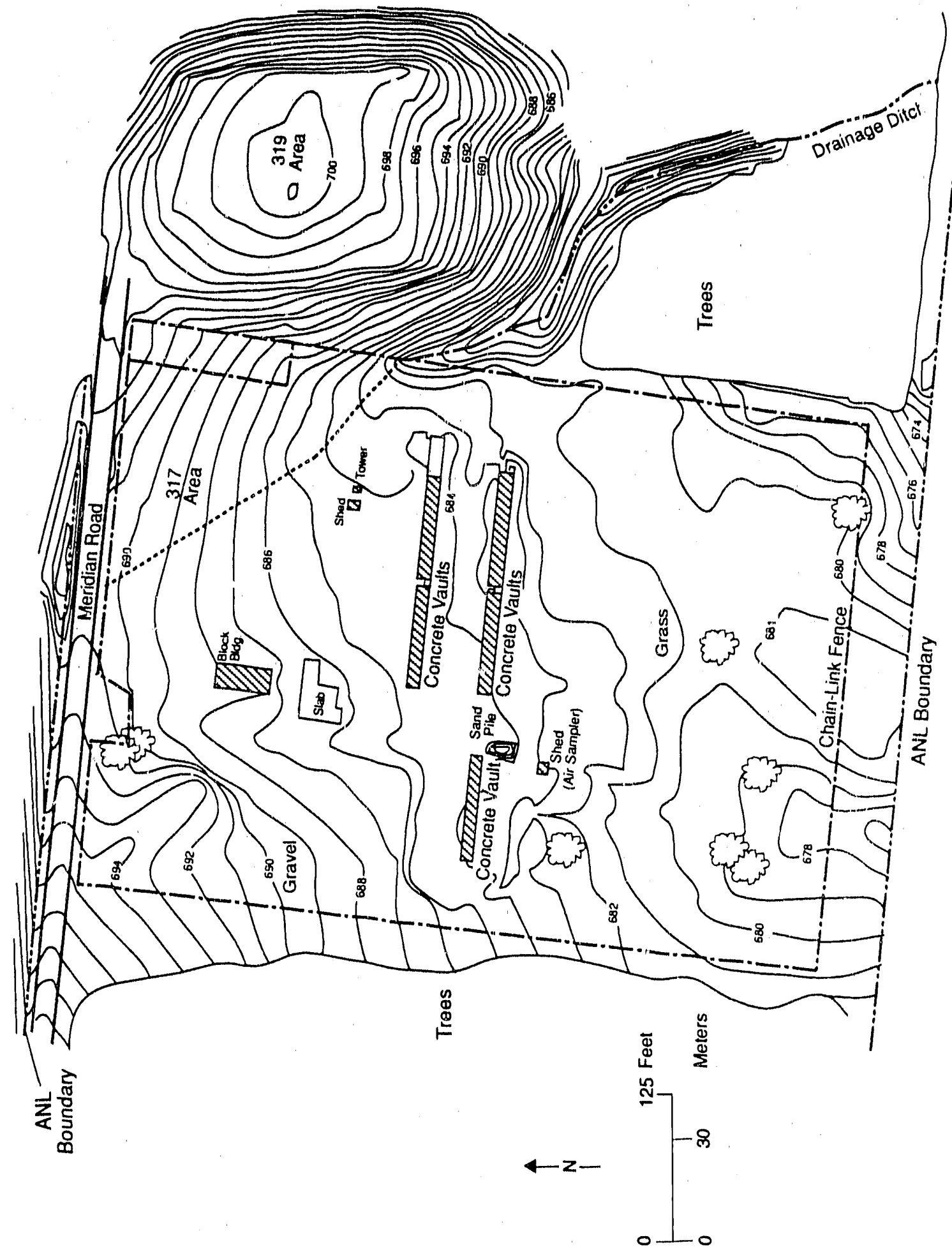

정 


\section{GEOLOGY}

ANL is located on a glacial till plateau that forms a complex arrangement of hills and depressions forming the Valnaraiso Morraine, which has a northwest-southeast trend. The glacial till covering the area consists of a heterogeneous mixture of silt, clay, and sand. Deposits of sand and gravel occur as discontinuous lenses throughout the till. Silurian-age dolomite forms the bedrock surface beneath the glacial till and crops out along the bluffs adjacent to the Des Plaines River valley and Sawmil' Creek.

\subsection{STRATIGRAPHY}

The stratigraphic column in Fig. 5 shows the sequence of lithologic units in DuPage County.

\subsubsection{Bedrock Geology}

Silurian-age dolomite bedrock beneath the $317 / 319$ Area occurs at an average depth of $19.5 \mathrm{~m}(64 \mathrm{ft}$ ) below the land surface (Will County Water \& Pump Co. 1988). The dolomite is underlain by the Ordovician-age Maquoketa shale group and the GalenaPlatteville cherty dolomite. The Maquoketa shale group functions as a confining stratum that separates the Niagaran and Alexandrian aquifers of the Silurian dolomite and the underlying Ordovician-age Galena-Platteville dolomite, Glenwood-St. Peter sandstone, and Prairie du Chien dolomite.

\subsubsection{Unconsolidated Deposits}

The glacial till underlying the $317 / 319$ Area consists of two units: the Lemont drift (till) and the overlying silty clay. The Lemont drift consists of a silty clay loam to silt loam and has an average fine-grained matrix (less than $2 \mathrm{~mm}$ ) of $16 \%$ sand, $64 \%$ silt, and $20 \%$ clay; ic was identified by the Illinois State Geological Survey (ISGS) in a study conducted at the Advanced Photon Source (APS) site at ANL, located about about $1.1 \mathrm{~km}$ $(3,600 \mathrm{ft}$ ) northwest of the $317 / 319$ Area (Fig. 2) (Killey and Trask 1989). The base of the Lemont drift consists of dolomite boulders, gravel, and rock fragments (shale and dolomite) that overly the dolomite bedrock.

The overlying glacial till unit consists of a silty clay matrix intermixed with sand, gravel, pebbles, and rock fragments (shale and dolomite). At the APS site, the average till thickness is about $43.5 \mathrm{~m}(143 \mathrm{ft})$. Analyses performed by the ISGS show that the average fine-grained matrix (less than $2 \mathrm{~mm}$ ) consists of $16 \%$ sand, $45 \%$ silt, and $39 \%$

clay (Killey and Trask 1989). Pebble content (greater than $2 \mathrm{~mm}$ ) was estimated to be 1-7\%. The till contains lenses consisting of sand, sand ard gravel, and silt that range in thickness from less than $0.3 \mathrm{~m}(1 \mathrm{ft})$ to about $1.2 \mathrm{~m}(4 \mathrm{ft})$. 


\begin{tabular}{|c|c|c|c|c|c|c|c|}
\hline SYSTEM & SERIES & $\begin{array}{l}\text { GROUP OR } \\
\text { GORMATION }\end{array}$ & $\begin{array}{c}\text { GEOHYDROLOGI } \\
\text { U?.ITS }\end{array}$ & & LOG & $\underset{\text { (FI) }}{\text { THICKNESS }}$ & DESCRIPTION \\
\hline 离视 & 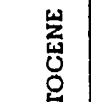 & & $\begin{array}{l}\text { Glacial } \\
\text { drift }\end{array}$ & & & $0-200 \pm$ & $\begin{array}{l}\text { Unconsolldated glacial deposits-pebbly } \\
\text { clay (till), silt, sand and gravel } \\
\text { Alluvial sllts and sands along streams }\end{array}$ \\
\hline & 峦 & . & aquifers & & & & Shale, sandy, brown to black \\
\hline NIAN & $a$ & & & & & Elllings & Dolomite, very pure to highly argillaceous, \\
\hline 蛋 & 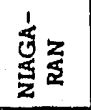 & $\begin{array}{l}\text { Racine } \\
\text { Waukesha } \\
\text { Jollet }\end{array}$ & $\begin{array}{l}\text { Nlagaran } \\
\text { aquifer }\end{array}$ & . & & $0-170$ & $\begin{array}{l}\text { silty, cherty; reefs in upper part } \\
\begin{array}{c}\text { Dolomite, shaly, and shale, dolomitlc; } \\
\text { maroon, green, oink }\end{array}\end{array}$ \\
\hline $\overrightarrow{\bar{E}}$ & 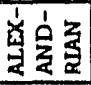 & $\begin{array}{l}\text { Kankakee } \\
\text { Edgewood }\end{array}$ & $\begin{array}{l}\text { Alexandrian } \\
\text { aquifer }\end{array}$ & $\begin{array}{l}\overrightarrow{8} \\
\text { d } \\
0\end{array}$ & & $0-90$ & $\begin{array}{l}\text { Dolomite, glaue.; thin grn. shale partings } \\
\text { Dolomite, argillaceous, silty and/or } \\
\text { sandy }\end{array}$ \\
\hline & & Neda & & $\stackrel{3}{=}$ & & $0-20$ & Shale, red; oolites \\
\hline & 空录 & Maquoketa & $\begin{array}{l}\text { Confining } \\
\text { beds of the } \\
\text { Maquinketa } \\
\text { Fortuaition }\end{array}$ & & & $85-230$ & $\begin{array}{l}\text { Shale, silty, dolomitic, greenish gray, } \\
\text { weak (Upper unit) } \\
\text { Dolomite and limestone, white, light } \\
\text { gray interbedded shale (Middle unit) }\end{array}$ \\
\hline 胥 & 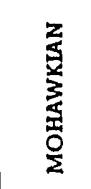 & $\begin{array}{l}\text { Galena } \\
\text { Decorah } \\
\text { Platteville }\end{array}$ & $\begin{array}{l}\text { Galena- } \\
\text { Platteville }\end{array}$ & & & $300-350$ & $\begin{array}{l}\text { Dolomite, and/or limestone, cherty } \\
\text { Dolomite, shale partings, speckled } \\
\text { Dolomite and/or limestone, cherty, } \\
\text { sandy at base }\end{array}$ \\
\hline 0 & & Glenwood & & 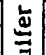 & & & Sandstone, fine and coarse gralned; little \\
\hline & 䒽 & St. Peter & $\begin{array}{l}\text { Glenwood- } \\
\text { St. Peter }\end{array}$ & 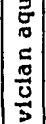 & & $200-375$ & $\begin{array}{l}\text { dolomite: shale at top } \\
\text { Sandstone, fine to medium gralned; } \\
\text { locally cherty red shale at base }\end{array}$ \\
\hline & 幽蛋 & $\begin{array}{l}\text { Shakopee } \\
\text { New } \\
\text { Richmond } \\
\text { Oneota } \\
\end{array}$ & $\begin{array}{l}\text { Prairle du } \\
\text { Chien }\end{array}$ & 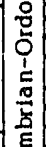 & & $0-200$ & $\begin{array}{l}\text { Dolomite, sandy, cherty (oolitic); sandstone } \\
\text { Sandstone interbedderd with dolomite } \\
\text { Dolomite, white to pink, coarse grained } \\
\text { cherty (oolitic), sandy at base }\end{array}$ \\
\hline \multirow{8}{*}{ 蛋 } & \multirow{8}{*}{ 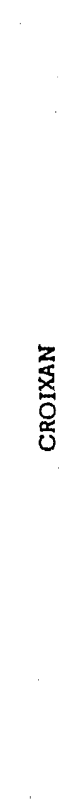 } & Trempealeau & Trempealeau & & & $80-190$ & $\begin{array}{l}\text { Dolomite, while, fine grained; geodic } \\
\text { quartz: sandy at base }\end{array}$ \\
\hline & & Franconia & Franconla & & & $70-100$ & $\begin{array}{l}\text { Dolomite, sandstone and shale, glau- } \\
\text { conitic, green to red, micaceous }\end{array}$ \\
\hline & & Ironton & \multirow{2}{*}{\multicolumn{2}{|c|}{$\begin{array}{l}\text { Ironton- } \\
\text { Galesville }\end{array}$}} & & \multirow{2}{*}{$175-200$} & \multirow{2}{*}{$\begin{array}{l}\text { Sandstone, fine to coarse grained, well } \\
\text { sorted; upper part dolomitic }\end{array}$} \\
\hline & & Galesville & & & & & \\
\hline & & Eau Claire & \multicolumn{2}{|l|}{$\begin{array}{l}\text { Confining beds } \\
\text { of the } \\
\text { Eau Claire } \\
\text { Formation } \\
\text { (upper and } \\
\text { middle beds) }\end{array}$} & & \multirow{4}{*}{$2,000 \pm$} & \multirow{4}{*}{$\begin{array}{l}\text { Sandstone, coarse grained, white, red } \\
\text { in lower half: lenses of shale and } \\
\text { siltstone, red, micaceous }\end{array}$} \\
\hline & & & \multirow{3}{*}{\multicolumn{2}{|c|}{$\begin{array}{l}\text { Eau Claire } \\
\text { (lower beds) } \\
\text { and } \\
\text { Mt. Simon } \\
\text { Formations }\end{array}$}} & \multirow{3}{*}{ 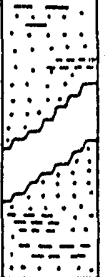 } & & \\
\hline & & Mt. Simon & & & & & \\
\hline & & & & & & & \\
\hline
\end{tabular}

\section{Zeizel et al. 1962)}


In the drillers' logs for the $317 / 319$ Area, no distinction was made between the Lemont drift and the clay till. Since the two tills are mainly distinguished by the relative amount of silt and clay, they cannot be differentiated without the aid of laboratory analysis. Thus, no attempt is made here to differentiate them.

\subsubsection{Site Stratigraphy}

Drillers' or geologists' logs describing the geologic materials encountered during drilling are available for 14 of the 1.6 monitoring wells and the 2 boreholes ( 8 and 9) arilled in the $317 / 319$ Area (see Fig. 3 and App. A). The logs, which record textural and color criteria, allow the sedimentary units to be correlated from well to well. Cross sections based on the drillers' logs are shown in Figs. 6 and 7 (see Fig. 3 for cross section locations). The log for well 7 did not contain enough detail to be useful in this endeavor. No boring data were recorded for wells 12 and 13 . Therefore, only two cross sections were made across the site.

The cross sections show that the $317 / 319$ Area is underlain by a silty clay till that is brown near the surface and grades with depth to a gray silty clay containing traces of gravel and sand. A sand lens is present at depths of $2.8 \mathrm{~m}(9.2 \mathrm{ft})$ and $5.3 \mathrm{~m}$ $(17.4 \mathrm{ft})$ at wells 5 and 2, respectively. The sand lens does not appear to be continuous throughout the southern part of the site because it does not extend to western well 6 or eastern well 3. A gravel and sand layer was identified at depths of $6.1 \mathrm{~m}(20 \mathrm{ft})$ at both

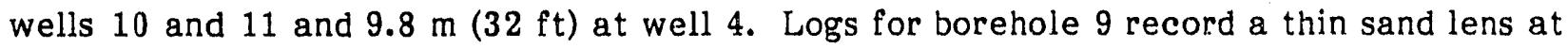
6.7-7.3 m (22-24 ft). Soil boring logs for well 1 also show a sand lens, consisting of coarse- to medium-grained sand with some coarse gravel, at a depth of about $5.8 \mathrm{~m}$. $(18.5 \mathrm{ft})$. This suggests that the sand and gravel lens at about $6 \mathrm{~m}$ is continuous acros; the site. Because logs were not recorded for wells 12 and 13 , the northern portion of the site cannot be adequately characterized.

Two wells (DH-3 and DH-4 -- see Fig, 3) have been drilled into the Silurian dolomite bedrock. Depths to the bedrock at wells $\mathrm{DH}-3$ and $\mathrm{DH}-4$ were $21.0 \mathrm{~m}(69 \mathrm{ft})$ and $18.0 \mathrm{~m} \mathrm{(59} \mathrm{ft),} \mathrm{respectively} \mathrm{(Will} \mathrm{County} \mathrm{Well} \mathrm{\&} \mathrm{Pump} \mathrm{Co.} \mathrm{19.3).} \mathrm{At} \mathrm{well} \mathrm{DH-3,} \mathrm{the}$

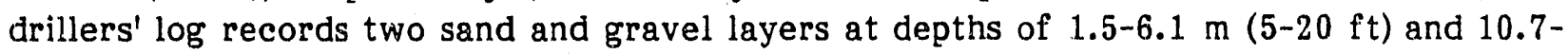
$21.0 \mathrm{~m}(35-69 \mathrm{ft})$. At $\mathrm{DH}-4$, two sand and gravel layers were encountered at $2.1-6.1 \mathrm{~m}$ $(7-20 \mathrm{ft})$ and $9.8-18.0 \mathrm{~m}(32-59 \mathrm{ft})$.

\subsection{HYDROLOGY}

\subsubsection{Surface Water}

Surface drainage at the $317 / 319$ Area is through a small ditch flowing southeast (see Figs. 3 and 4) toward the Des Plaines River, which is located about $1.2 \mathrm{~km}(0.7 \mathrm{mi})$ to the south. 


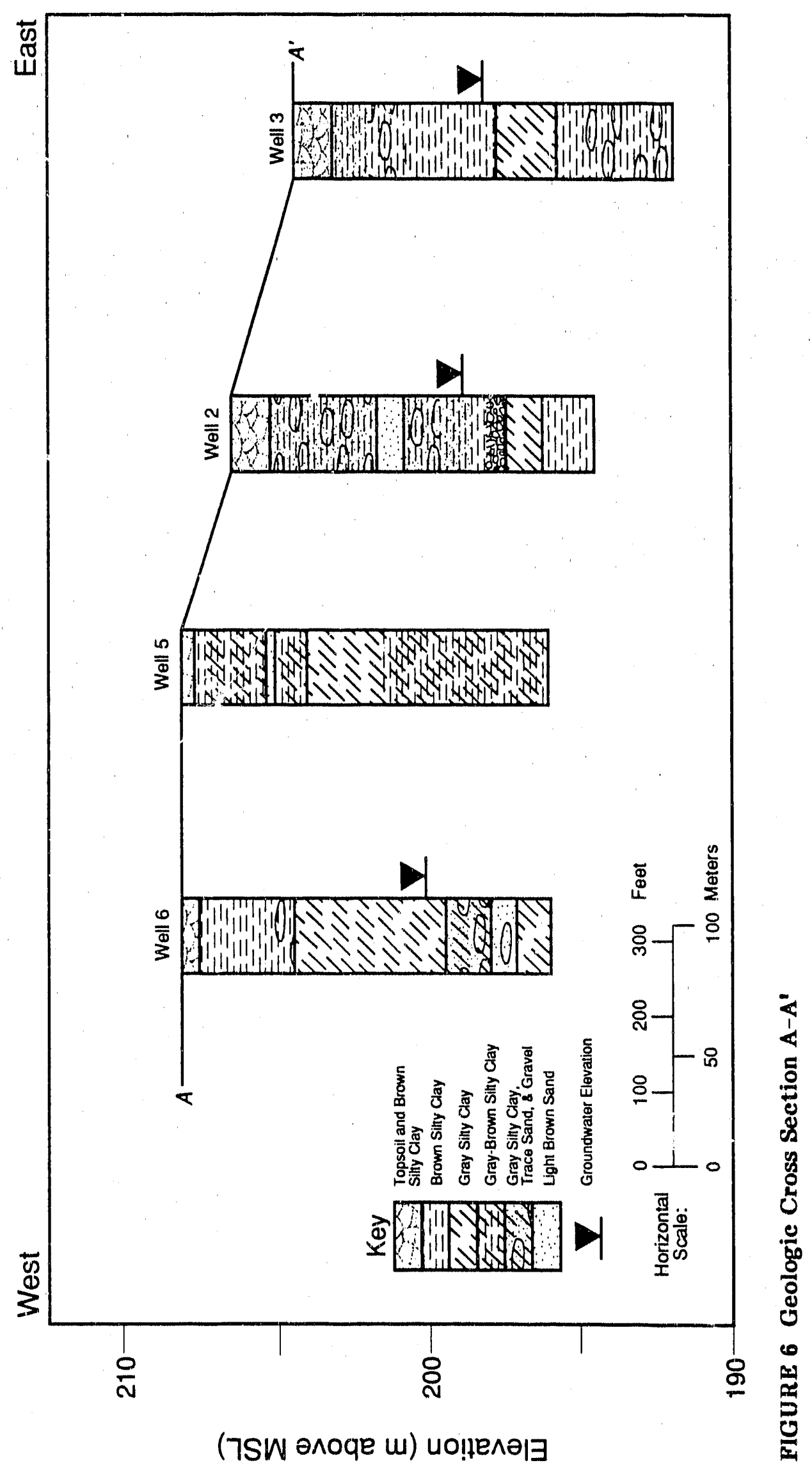




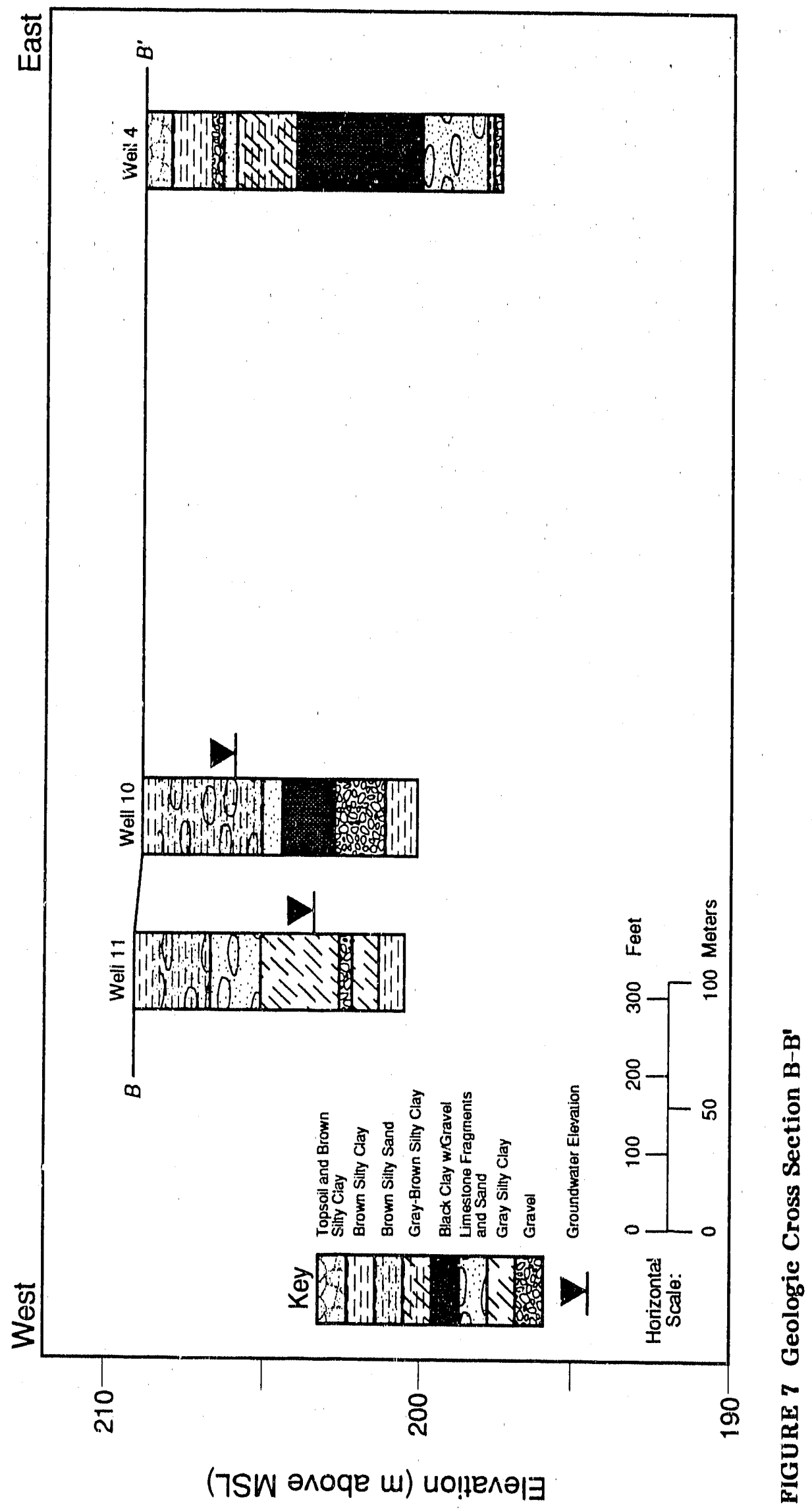




\subsubsection{Groundwater}

Groundwater under ANL and the 317/3.19 Area is found in the Silurian dolomite bedrock and in the overlying glacial till. The Silurian dolomite consists of two aquifers: the Niagaran Series and the underlying Alexandrian Series (Fig. 5). The Niagaran dolomite occurs at depths of greater than $18.0 \mathrm{~m}(59 \mathrm{ft})$ in the $317 / 319$ Area. Figure 8 shows the topographic features of the Niagaran dolomite surface under ANL. The unit may be greater than $61 \mathrm{~m}(200 \mathrm{ft})$ in thickness. The Niagaran Series dolomite is a zone of relatively high permeability and is the most productive of the Silurian dolomite aquifers (Zeizel et al. 1932). Groundwater occurs in openings in the dolomite and moves through a complex network of interconnected joints, fractures, and solution cavities (Zeizel et al. 1962). Vertical leakage through the glacial till recharges the aquifer.

Groundwater occurs in the till at shallow depths where recharge (precipitation) is able to migrate through small fractures in the weathered portions of the clay and in the small sand and gravel lenses distributed throughout the till.

\subsubsection{Contaminant Migration Potential}

Potential contaminants from the $317 / 319$ Area migrating downward in groundwater may be greatly retarded by the slow rate of percolation through the nearly impermeable clay in the glacial tili; however, contaminants could migrate via fractures and the sand and gravel lenses present in the clay till and reach the dolomite aquifer. This is of concern since the dolomite aquifer provides much of the groundwater used in southern DuPage County and at ANL. The groundwater in the dolomite aquifer below the site flows southeast, discharging into the Des Plaines River about $914 \mathrm{~m}(3,000 \mathrm{ft})$ from the site. Since no drinking water supplies are located between the 317/319 Area and the river (the area is a forest preserve), the potential for human consumption is considered to be low. Figure 9 shows a 1960 illustration of the piezometric surface of water in the Silurian (Niagaran) dolomite at ANL. More recent data are not available. The two depressions in the piezometric surface below the ANL site are the result of removal of water from the aquifer by three ANL domestic water supply wells. 

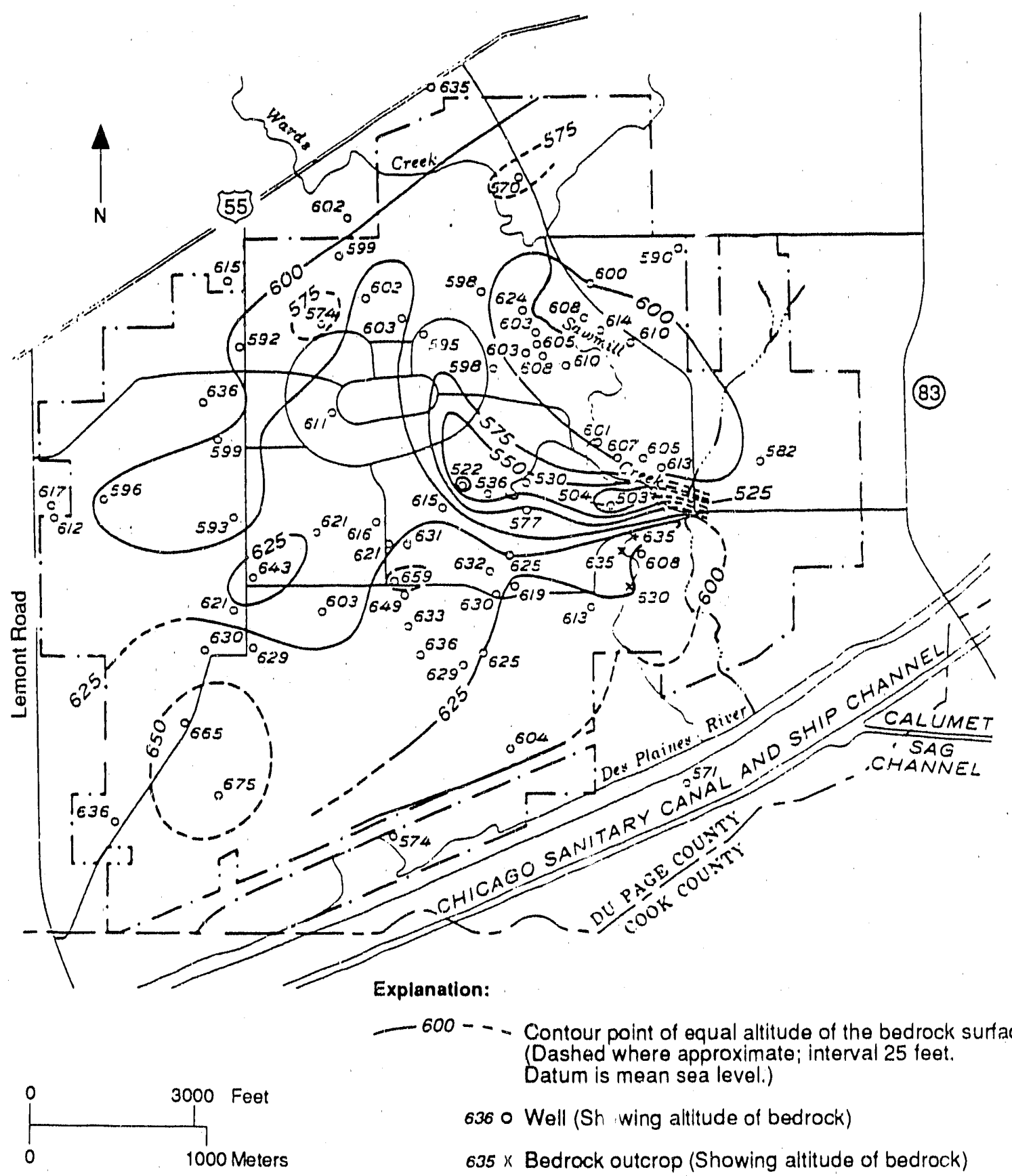

FIGURE 8 Approximate Elevation of the Niagaran Dolomite Bedrock Surface at ANL (Source: Modified from Knowles et al. 1963) 

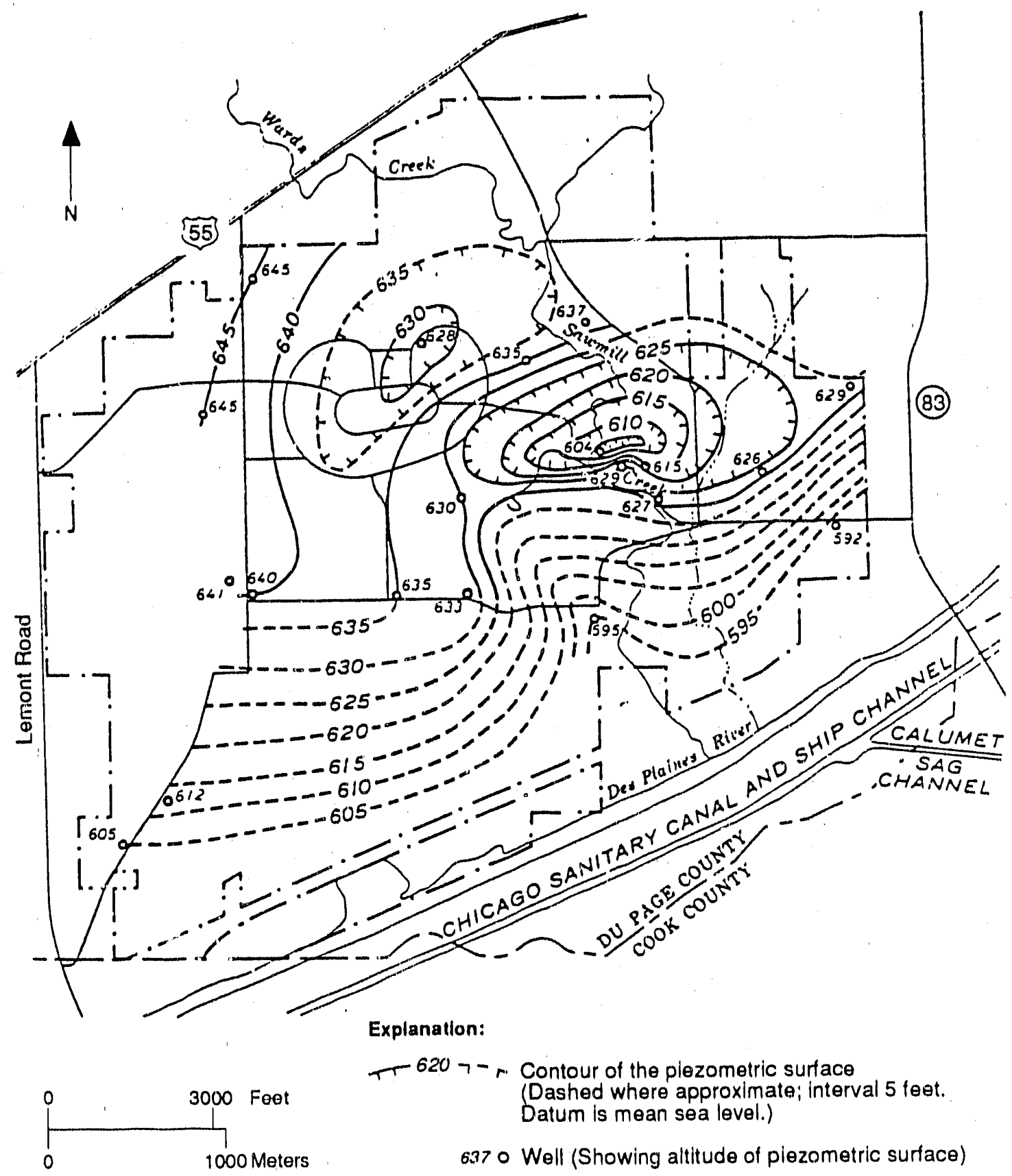

FIGURE 9 Piezometric Surface of Groundwater in the Niagaran Dolomite at ANL, June 1960 (Source: Modified from Knowles et al. 1963) 


\section{GROUNDWATER CONDITIONS AT THE 317/319 AREA}

\subsection{EXISTING WELL NETWORK}

As part of the environmental monitoring program at ANL, ESH has installed 15 groundwater monitoring wells around the $317 / 319$ Area since 1986. One well was installed by the U.S. Department of Energy (DOE) Environmental Survey Team in 1987. Initially drilled to measure local groundwater elevations and possible inorganic chemical or radioactive contaminants in the groundwater, in recent yfars the wells have been used to munitor organic chemicals as well. See Fig. 3 for the well locations and App. A for available cons ruction diagrams and drillers' and geologists' logs.

Wells 1 through 4 were installed in September 1986. Because the general groundwater flow was assumed to be to the south, well 1 was installed north of the $317 / 319$ Area as a control well. Wells 2 through 4 were placed on the southern perimeter to monitor water leaving the site. Well 4 has been dry since its emplacement. Depths of these wells range from 11.3 to $12.5 \mathrm{~m}$ ( 37 to $41 \mathrm{ft}$ ), and they are screened at the bottom with $1.5-\mathrm{m}(5-\mathrm{ft})$ screens.

In July 1987, wells 5 and 6 were drilled along the southern perimeter of the site. Well 5 was drilled to a depth of $11 \mathrm{~m}(36 \mathrm{ft}$ ), but, due to collapse at the bottom of the hole, it was completed at a depth of $6.2 \mathrm{~m}(20.5 \mathrm{ft})$; it has been dry since its emplacement. Well 6 was drilled to a depth of $12.2 \mathrm{~m}(40 \mathrm{ft})$. Both wells were screened at the bottom with $1.5-m(5-f t)$ screens.

Well 7 was installed in the 319 landfill area by the DOE Environmental Survey Team in August 1987 and drilled to a depth of $19.2 \mathrm{~m}(63 \mathrm{ft})$. It was screened at th? bottom with a $3.0-\mathrm{m}(10-\mathrm{ft})$ stainless-steel screen 4 in. in diameter. Well 7 has been dry since its emplacement.

Boreholes were drilled to $9.1 \mathrm{~m}$ ( $30 \mathrm{ft}$ ) g.t locations 8 and 9 just south of the northern vaults in April 1988. After split-spoon samples were taken, the holes were filled with grout.

Wells 10 and 11 , located about $6 \mathrm{~m}(20 \mathrm{ft})$ south of the southern vaults, were drilled in July 1988 to $9.3 \mathrm{~m}(30.5 \mathrm{ft})$. These wells were screened at the bottom with $3-\mathrm{m}$ $(10-\mathrm{ft})$ screens.

Wells 12 and 13 , located on the northwest corner of the 317 Area fence, were

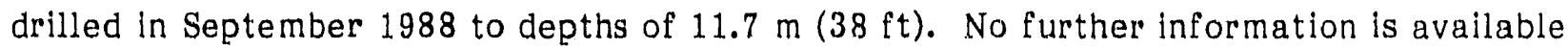
regarding these wells. Also in September 1988, wells $\mathrm{DH}-3$ and $\mathrm{DH}-4$ were drilled into the dolomite at total depths of $24.1 \mathrm{~m}(79 \mathrm{ft})$ and $21.0 \mathrm{~m}(69 \mathrm{ft})$, respectively. The $\mathrm{DH}$ wells are cased with carbon steel and are not screened.

In August 1989, a new well was drilled near well 3 and two replacernent wells were drilled near well 5. The new well near well 3 was drilled to a depth of $4.6 \mathrm{~m}$ (15 ft) and was designated well 3-15. Two replacement wells for well 5 were drilled to depths of $4.3 \mathrm{~m}(14 \mathrm{ft})$ and $7.6 \mathrm{~m}(25 \mathrm{ft})$ and designated as well 5-15 and well 5-25, respectively. 
The old well 5 was sealed. A 4.6-m $(15-\mathrm{ft})$ borehole was drilled near well 2 in an effort to locate and place a well in one of the sand/gravel lens found at that depth; because the soll was dry and the sand layer was not found, the well was not completed.

The depths of the monitoring wells drilled into the glacial till range from 4.6 to $19.2 \mathrm{~m}$ (15 to $6 \mathrm{~s} \mathrm{ft}$ ). Except for wells 7, $\mathrm{DH}-3$, and $\mathrm{DH}-4$, polyvinyl chloride (PVC) casing and screens were used. The wells were screened at the bottom with $1.5-m(5-\{t)$ screens (except for wells 7,10 , and 11 , which have 10-ft screens) and packed with either pea gravel or silica sand over intervals ranging from 2.0 to $7.2 \mathrm{~m}(6.5$ to $23.5 \mathrm{ft})$. Table 2 provides a surumary of the design and construction of monitoring wells at the $317 / 319$ Area. Figure 10 is a scherratic diagram comparing the monitoring intervals of all wells completed in the till.

\subsection{DIRECTION OF GROUNDWATER FLOW}

Groundwater in the glacial till is unconfined and occurs at shallow depths. The fact that some wells yield water and others do not at the same depth (e.g., wells 2 and 3) indicates that the water table drops in places, possibly due to differences in hydraulic conductivity. Since 1986, ESH has measured static water levels in the till wells quarterly (see App. B). Sampling and water-level measurement of the two dolomite wells was begun in late 1989; however, these data were not available when this report was prepared.

Table 3 gives shallow water table elevations for four recent quarters $(5 / 89,3 / 89$, 11/88, and 9/88), and Fig. 11 shows the elevation contours, based on May 1989 data, for all wells completed in the till. The direction of groundwater movement is at right angles to the contours. The figure indicates that the predominant direction of groundwater flow is southeast, toward the river, although groundwater may flow to the east and south in some locales. Estimates of the hydraulic gradient range from 0.022 to 0.085 .

\subsection{RATE OF GROUNDWATER FLOW}

\subsubsection{Horizontal Flow}

If groundwater flow is assumed to be predominantly horizontal, the rate of horizontal groundwater flow in an aquifer is determined by its hydraulic gradient, hydraulic conductivity, and porosity. The velocity magnitude may be calculated using the following equation:

$$
v=-(K / n) \times(d h / d l)
$$

where:

$$
\begin{aligned}
& \mathrm{v}=\text { average linear velocity, } \\
& \mathrm{K}=\text { hydraulic conductivity, }
\end{aligned}
$$




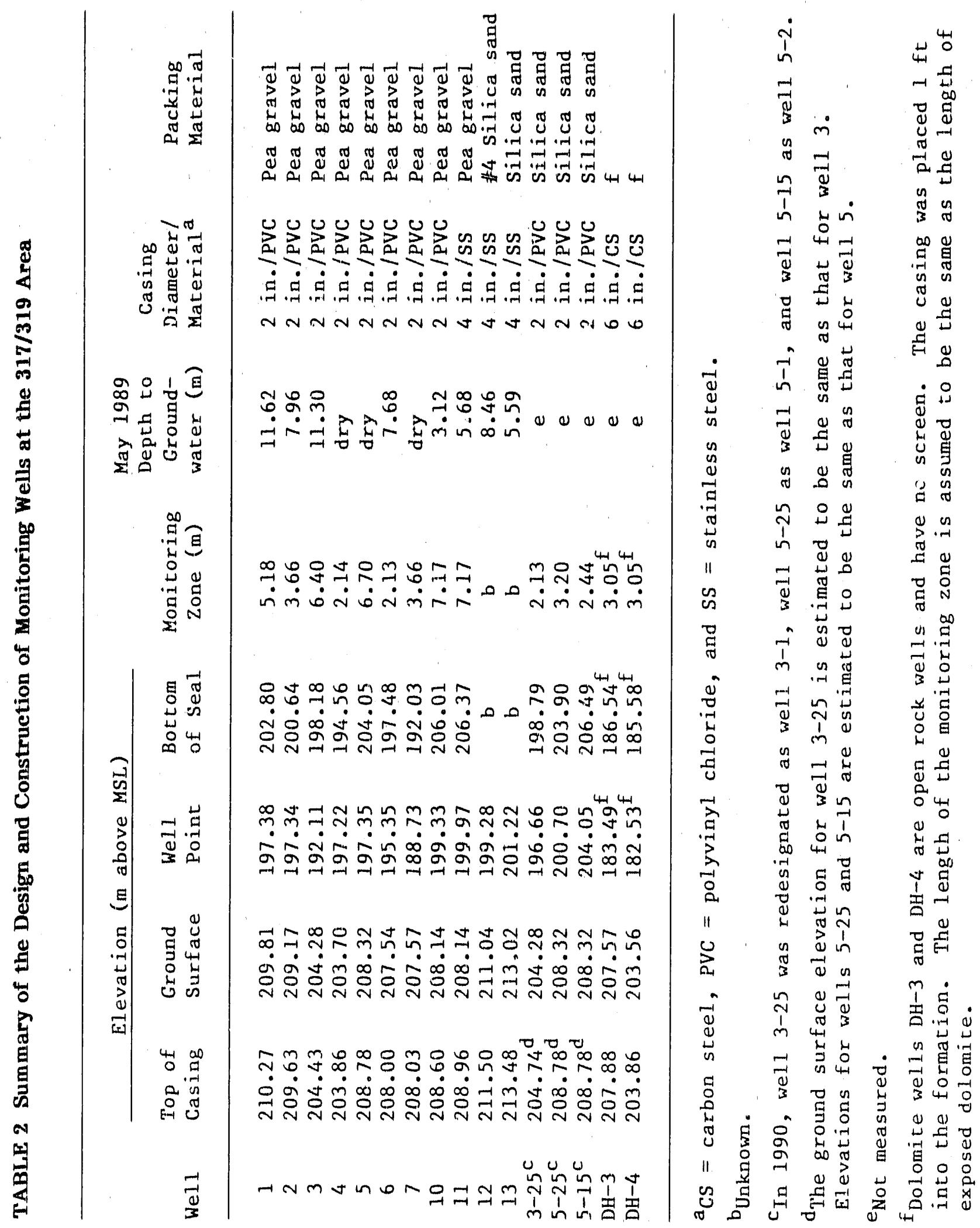




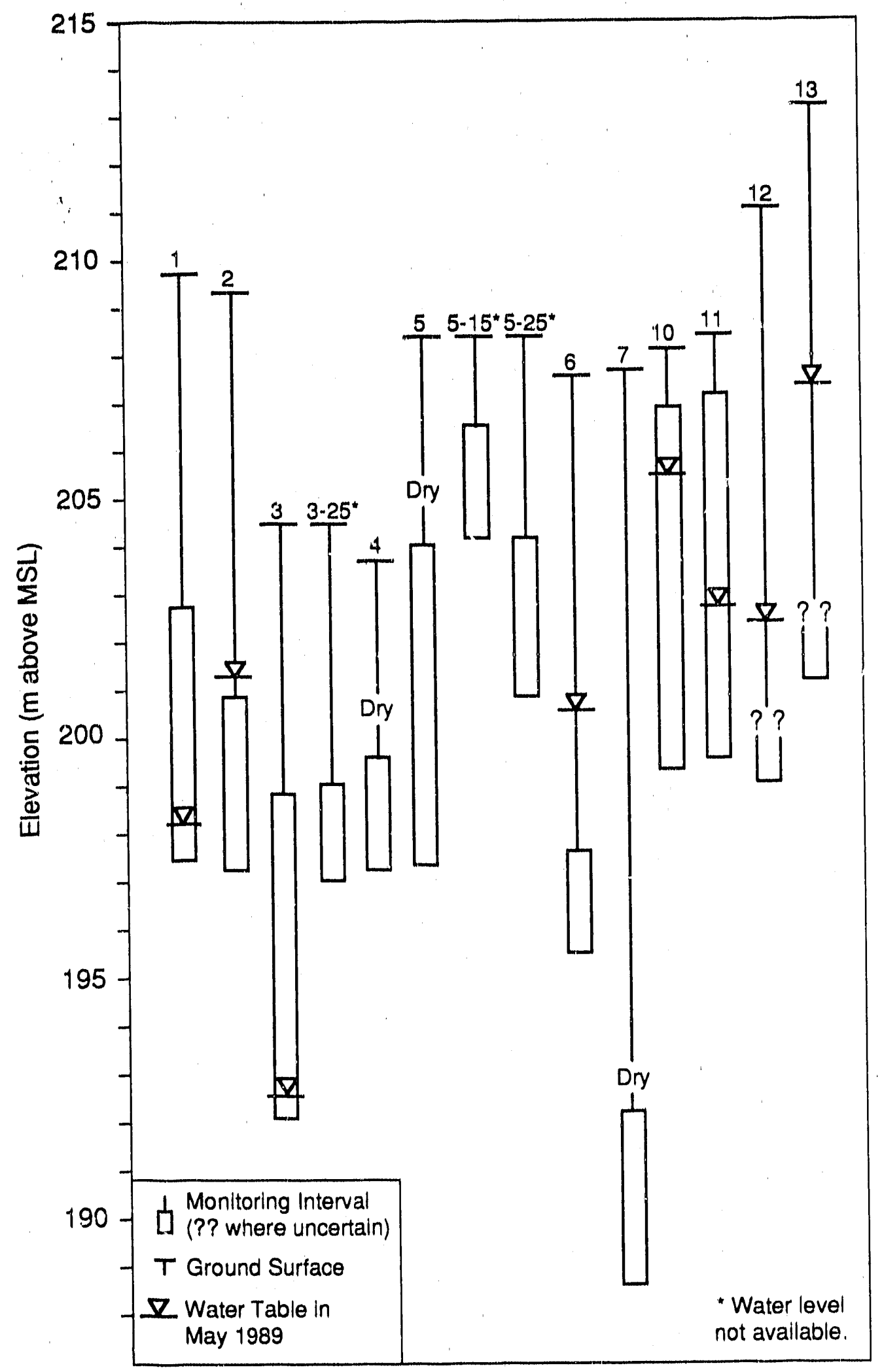

FIGURE 10 Schematic Diagram of Well Point Elevations and Monitoring Intervals for All Monitoring Wells Completed in the 'Till at the $317 / 319$ Area 
TABLE 3 Well Point and Water Elevations of Monitoring Wells Completed in the Till at the 317/319 Area, 1988-1989 (m above MSL)

\begin{tabular}{|c|c|c|c|c|c|c|c|}
\hline \multirow[b]{2}{*}{ We11. } & \multirow{2}{*}{$\begin{array}{l}\text { Ground } \\
\text { Surface } \\
\text { Elevation }\end{array}$} & \multirow[b]{2}{*}{ Depth } & \multirow{2}{*}{$\begin{array}{c}\text { Well } \\
\text { Point } \\
\text { Elevation }\end{array}$} & Quarterly & \multicolumn{2}{|c|}{ Groundwater } & Elevations ${ }^{a}$ \\
\hline & & & & $9 / 88$ & $11 / 88$ & $3 / 89$ & $5 / 89$ \\
\hline 1 & 209.81 & 12.43 & 197.38 & 198.58 & 197.77 & 197.59 & 198.19 \\
\hline 2 & 209.17 & 11.83 & 197.34 & 202.42 & 197.92 & 199.32 & 201.21 \\
\hline 3 & 204.28 & 12.17 & 192.11 & dry & dry & dry & 192.98 \\
\hline 6 & 207.54 & 12.19 & 195.35 & 198.49 & 198.41 & 1.99 .66 & 200.46 \\
\hline 10 & 208.14 & 8.81 & 199.33 & 203.79 & 204.79 & 205.40 & 205.02 \\
\hline 11 & 208.50 & 8.53 & 199.97 & 201.70 & 202.25 & 204.10 & 202.82 \\
\hline 12 & 211.04 & 1.1 .76 & 199.28 & 202.58 & 201.59 & 201.87 & 202.58 \\
\hline 13 & 213.02 & 11.80 & 201.22 & 205.05 & 206.19 & 207.50 & 207.43 \\
\hline
\end{tabular}

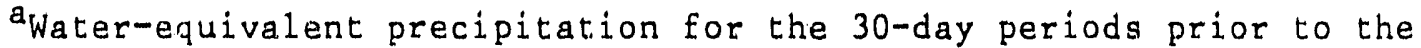
measurements was $59.2 \mathrm{~mm}$ for $9 / 88,125.0 \mathrm{~mm}$ for $11 / 88,47.2 \mathrm{~mm}$ for $3 / 89$, and $24.6 \mathrm{~mm}$ for $5 / 89$. The 1988 values are from the meteorological station at O'Hare International Airport, and the 1989 values are from the station at ANL.
}

$$
\begin{aligned}
\mathrm{n} & =\text { volumetric porosity, and } \\
\mathrm{dh} / \mathrm{dl} & =\text { hydraulic gradient (Freeze and Cherry 1979). }
\end{aligned}
$$

The negative sign indicates that the flow is in the direction of decreasing hydraulic head.

Hydraulic conductivity values have been determined by the ISGS for the till underlying the APS site, about $1.1 \mathrm{~km}(3,600 \mathrm{ft}$ ) northwest of the $317 / 319$ Area (Killey and Trask 1989). The values, which were derived by slug testing, range from $3.2 \times 10^{-7} \mathrm{~cm} / \mathrm{s}$ $\left(2.8 \times 10^{-4} \mathrm{~m} / \mathrm{d}\right)$ to $4.2 \times 10^{-6} \mathrm{~cm} / \mathrm{s}\left(3.6 \times 10^{-3} \mathrm{~m} / \mathrm{d}\right)$. These values are greater than the range of $10^{-9}$ to $10^{-7} \mathrm{~cm} / \mathrm{s}$ reported by Berg et al. (1984) for Illinois till containing greater than $25 \%$ clay.

By using the APS site values for hydraulic conductivity, the horizontal groundwater velocity at the $317 / 319$ Area was estimated to range from $1.7 \times 10^{-2}$ to $5.8 \times 10^{-2} \mathrm{~m} / \mathrm{yr}(17$ to $58 \mathrm{~cm} / \mathrm{yr})$. For the calculation, the hydraulic gradient was assumed to range from 0.022 to 0.085 and the volumetric porosity (for clay) was assumed to be 50\% (U.S. EPA 1989). 


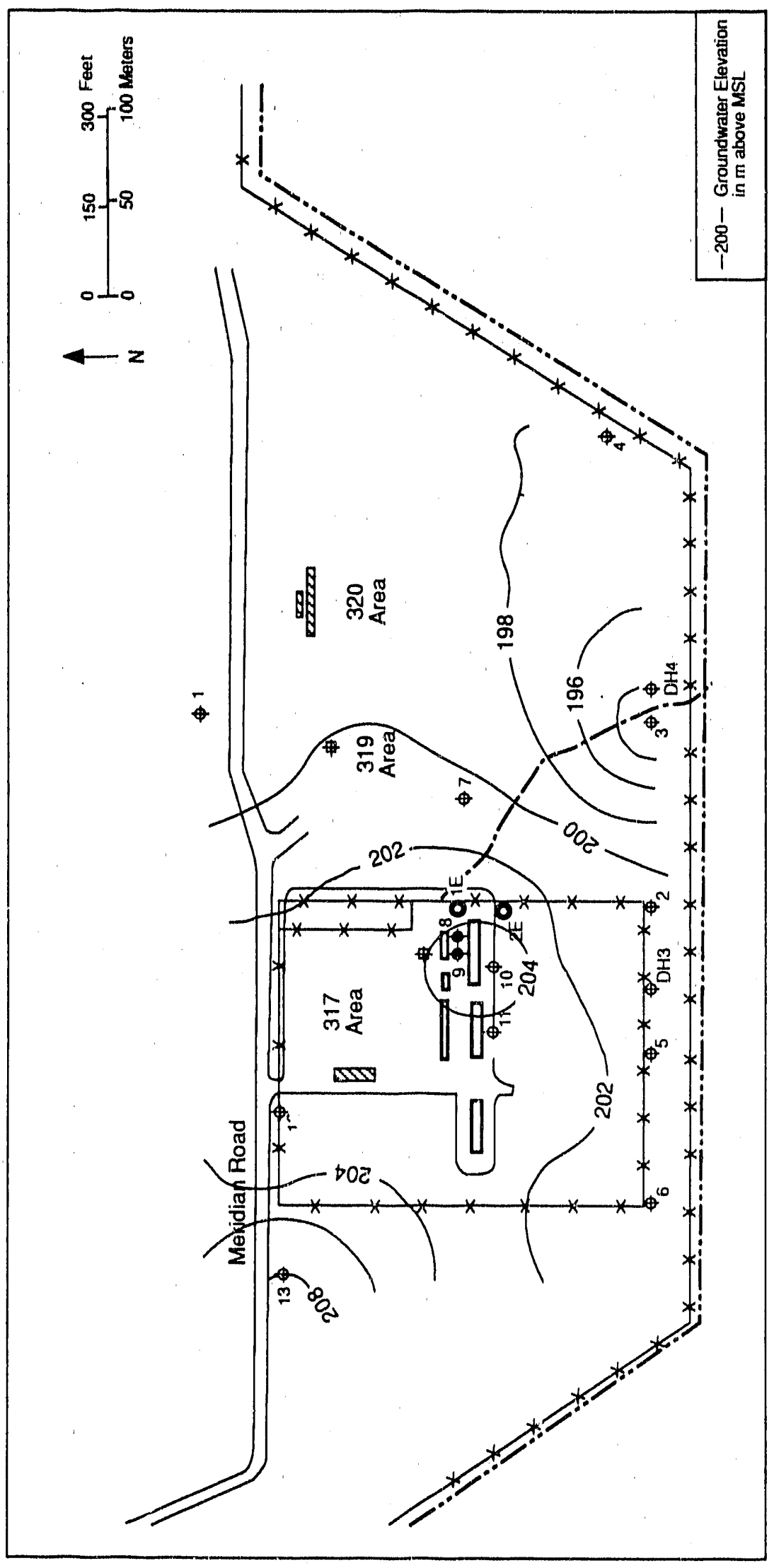

 


\subsubsection{Vertical Flow}

Although it is not possible to calculate the vertical gradient based on the available information, a plot of water levels against well depth indicates that there may be a significant romponent of downward flow. Nested wells are needed to quantify this downward component.

\subsection{GROUNDWATER LEVRL FLUCTUATIONS}

Figure 12 is a hydrograph showing water level variations for all monitoring wells completed in till in the 317/319 Area. Water levels, which have remained fairly stable over time, are generally lowest during the third and fourth quarters due to seasonal changes in precipitation and evapotranspiration. Water levels did not decline significantly in response to the 1988 summer drought (relative to summer 1987).

\subsection{GROUNDWATER QUALITY}

\subsubsection{Detected Contaminants}

Groundwater quality data for 1988 analyses for wells completed in the till are summarized in Tables 4 and 5 . When this report was prepared, no chemical data were

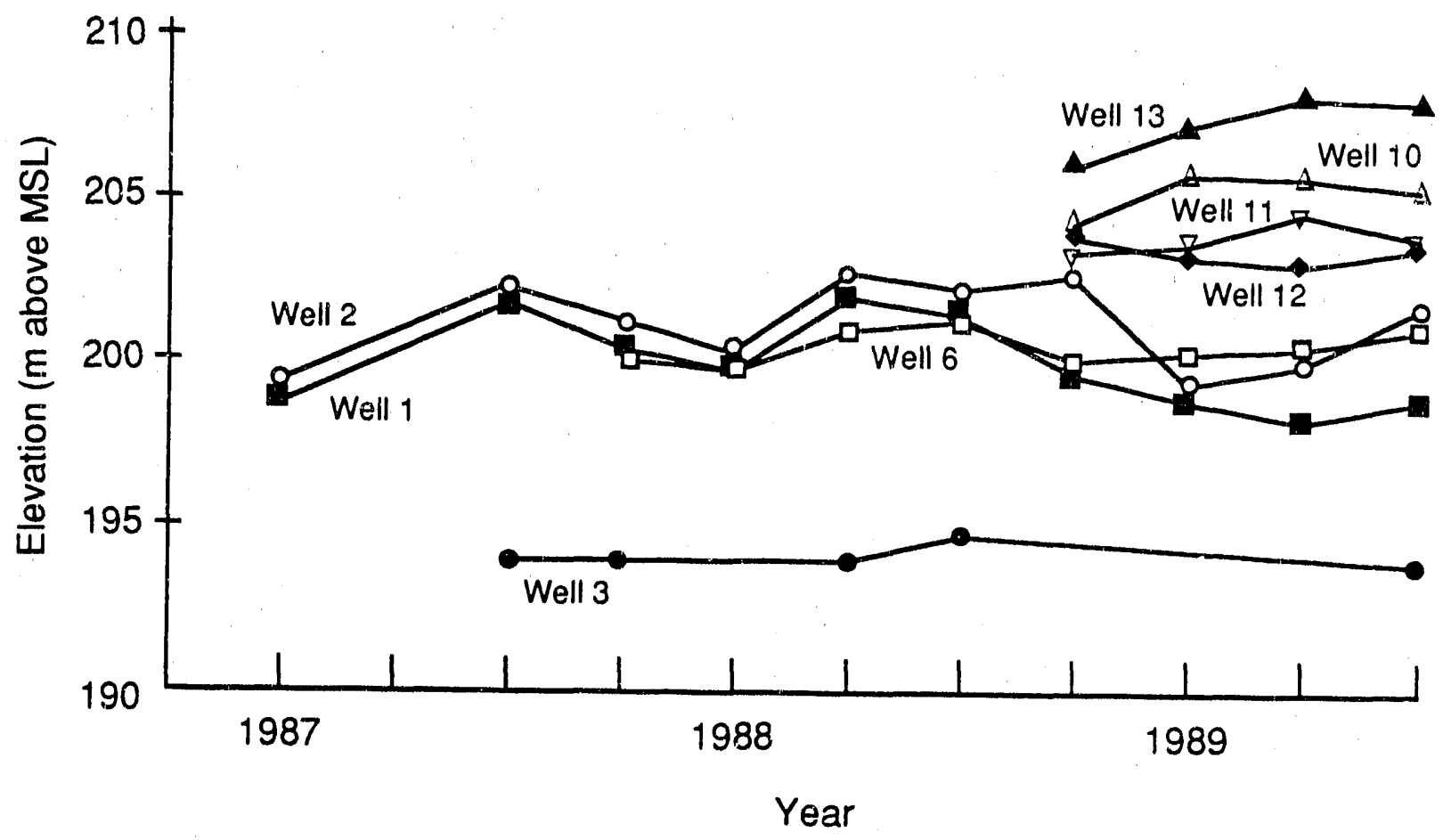

FIGURE 12 Groundwater Elevations for Monitoring Wells Completed in the Till; 1986-1989 (the absence of a point on a curve indicates a quarter during which no measurements were made) 


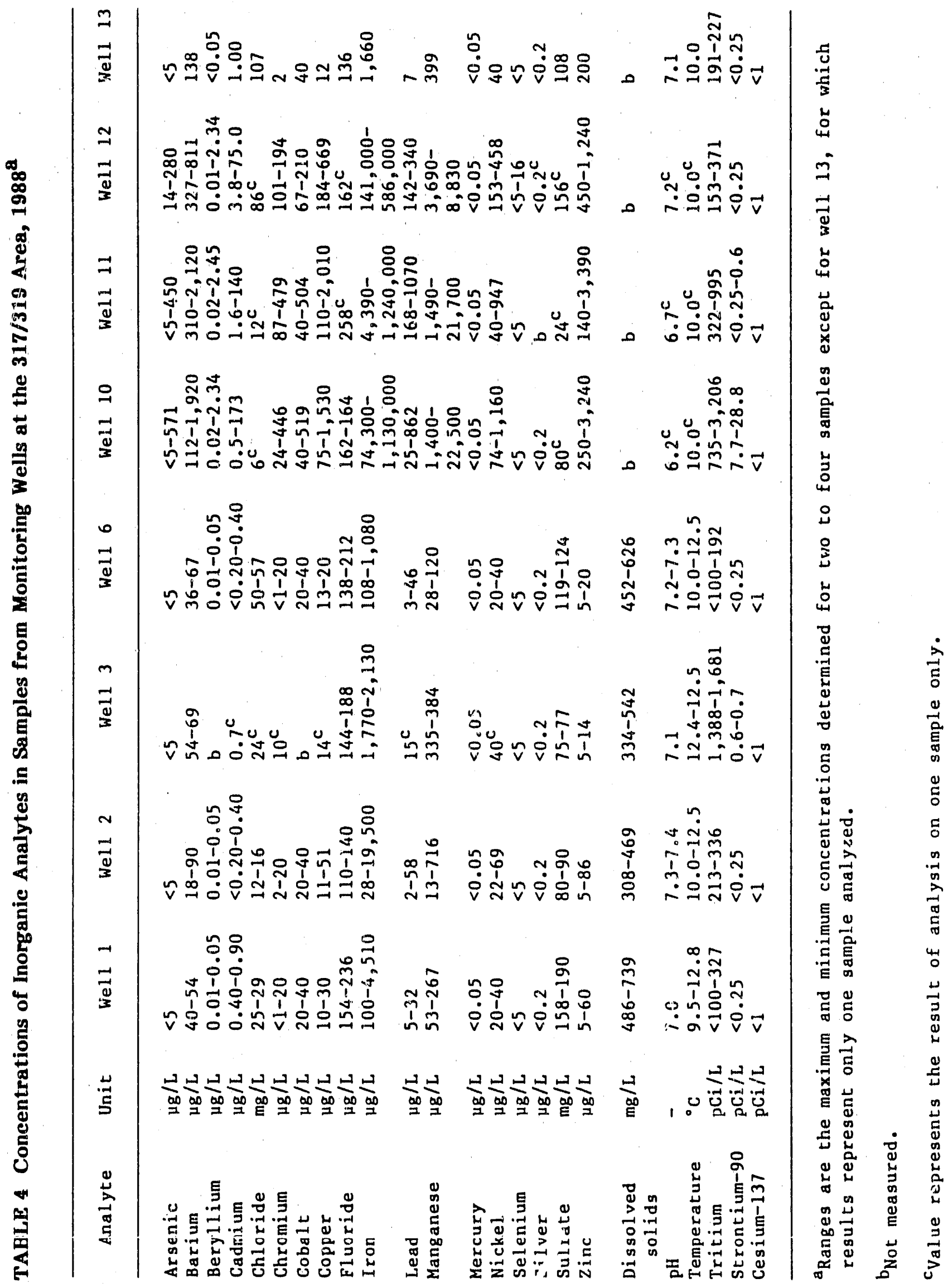


TABLE 5 Concentrations of Organic Analytes in Samples from Monitoring Wells at the $31 \% / 319$ Area, $1988(\mu \mathrm{g} / \mathrm{L})$

\begin{tabular}{|c|c|c|c|c|c|}
\hline Well ${ }^{a}$ & Compound & $5 / 19 / 88$ & $6 / 17 / 88$ & $9 / 15 / 88$ & $11 / 16 / 88$ \\
\hline 2 & $\begin{array}{l}\text { 1,1-Dichloroethane } \\
\text { 1,2-Dichloroethane } \\
\text { 1,1,1-Trichloroethane } \\
\text { Chloroform } \\
\text { Carbon tetrachloride }\end{array}$ & $\begin{array}{l}18 \\
N^{C} \\
28 \\
2 \cdot 3 \\
N D\end{array}$ & $\begin{array}{l}25 \\
\text { ND } \\
26 \\
5.0 \\
\text { ND }\end{array}$ & $\begin{array}{l}60 \\
\text { ND } \\
39 \\
5.0 \\
6\end{array}$ & $\begin{array}{l}50,45^{b} \\
64,60 b \\
46,49^{b} \\
\text { ND } \\
16\end{array}$ \\
\hline 3 & 1,1-Dichloroethane & ND & 0.4 & $d$ & $d$ \\
\hline 10 & $\begin{array}{l}\text { 1,2-Dichloroethene } \\
\text { Trichloroethene }\end{array}$ & - & - & $\begin{array}{c}11^{\mathrm{e}} \\
8\end{array}$ & $\begin{array}{l}48^{f} \\
105\end{array}$ \\
\hline 11 & $\begin{array}{l}\text { 1,1-Dichloroethane } \\
\text { 1,2-Dichloroethene } \\
\text { 1,2-Dichloroethane } \\
\text { 1,1,1-Trichloroethane } \\
\text { Trichloroethene }\end{array}$ & $\begin{array}{l}- \\
- \\
- \\
-\end{array}$ & $\begin{array}{l}- \\
- \\
-\end{array}$ & $\begin{array}{r}170 \\
10 \\
21 \\
160 \\
36\end{array}$ & $\begin{array}{l}{ }_{9}^{8} \\
\text { ND } \\
\text { ND } \\
\text { ND }\end{array}$ \\
\hline 12 & Diethyl phthalate & - & - & $<10$ & $g$ \\
\hline 13 & 4-Methyl fluorene & - & - & - & $g$ \\
\hline
\end{tabular}

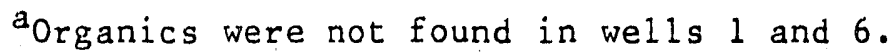

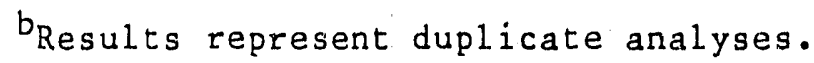

${ }^{\mathrm{C}}$ Not detected.

$\mathrm{d}_{\text {Well }}$ was dry (no sample collected).

Both cis and trans isomers.

${ }^{E_{C i s}}$ isomer only.

Gentatively identified.

Source: Golchert and Duffy 1989. 
available for the dolomite wells. Concentrations of metals (cobalt, copper, iron, lead, manganese, nickel, and zinc) are much higher in groundwater from wells 10,11 , and 12 than in other wells. According to Golchert and Duffy (1989), this is inost probably due to the fact that the wells were not completely developed by the September sampling date and therefore may have contained an abundance of suspended solids to which the metals adsorbed.

Samples were collected quarterly in 1988 and analyzed for volatile organic compounds (VOCs). In September 1988, samples collected from all wells except well 13 were also analyzed for semivolatile organics, PCBs, and pesticides (Golchert and Duffy 1989). Table 5 shows the results of the VOC analyses. Trichloroethane, 1,1,1-trichloroethane, and 1,2-dichloroethane, present in wells 2,10 , and 11 , represent material known to be disposed of in the $317 / 319$ Area. The compounds 1,1 -dichloroethane and cis-1,2-dichloroethene, also present in wells 2,10 , and 11 , are thought to result from biodegradation of tetrachloroethene, trichloroethene, and 1,1,1-trichloroethane by microorganisms (Golchert and Duffy 1989). Small amounts of carbon tetrachloride and chloroform were found in well 2. No semivolatile organic compounds, PCBs, or pesticides were detected.

\subsubsection{Rate of Solute Transport}

To estimate the transport rate for specific contaminants in groundwater, soil information such as bulk density, particle density, total organic content, and porosity must be known. Currently, this information is not available. 


\section{CONCLUSIONS AND RECOMMENDATIONS FOR FURTHER STUDY}

\subsection{CONCLUSIONS}

To date, the groundwater monitoring program conducted by ESH has ylelded useful information on the direction of groundwater flow and contaminants in the gr undwater. The next phase in assessing the hydrological conditions at the $317 / 319$ Area should answer questions regarding the physical characteristics (bulk density, particle density, organic content, porosity, and hydraulic conductivity) of the glacial till and the dolomite bedrock. This information is needed to make reliable geologic cross sections across all portions of the site, to identify potential pathways for contaminant migration, and to estimate rates of groundwater movement (vertical and horizontal flow directions) and contaminant migration.

The review of the monitoring program reveals that there is little or no information on the groundwater levels or chemical quality of the dolomite aquifer beneath the site. It is very important to characterize the dolomite aquifer since it is $a$ major drinking water source in DuPage County.

No well design and construction data are avallable for wells 12 and 13 . Wells 4 and 7 have been consistently dry. These wells should be decommissioned and sealed.

Finally, a provision should be added to the current standard operating procedures manual to ensure that field personnel document all field activities and that thorough records be kept during the drilling of well bores and the installation of wells (see Table 6).

\subsection{RECOMMENDATIONS}

\subsubsection{Definition of Subsurface Geology}

In order to identify potential pathways of contamination, it is necessary to understand more compietely the subsurface geology beneath the $317 / 319$ Area. Needs for additional data are discussed in the following sections.

\subsubsection{Soil Borings}

Soil borings should be drilled at discrete locations near the French drains. These wiil provide information on subsurface characteristics as well as data on the vertical exteri $i$ of contamination near the drains.

For many of the existing wells, the boring logs lack the information needed to adequately depict significant subsurface characteristics, such as the precise depth of small- and large-scale permeable layers (sand and gravel lenses) and the depth at which water is first encountered, especially in the 319 Area. During the drilling of new wells in 
TABLE 6 Information That Should Be Logged in the Field during the Drilling of Well Bores

\section{General}

Project name

Hole name/number

Date started/finished

Geologist's name

Driller's name

Sheet number (e.g., "2 of 3")

Hole location (map)

Information Columns

Depth

Sample location/number

Bl.ow counts and advance rate
Ground surface elevation at hole

Rig type, bit/auger size

Petrologic/lithologic classification system used (e.g., Wentworth or unified soil)

Weather

\section{Narrative Description}

Geologic observations

- Soil/rock type

- Color and staining

- Gross petrology

- Friability

- Moisture content

- Degree of weathering

- Pwesence of carbonate

Drilling observations

- Loss of circulation

- Advance rates

- Rig chatter

- Water levels

- Air volume/pressure

- Drilling difficulties
- Fractures

- Solution cavities

- Bedding

- Discontinuities (foliation)

- Water-bearing zones

- Formational strike and dip
- Depositional structures

- Organic content

- Odor

- Suspected contaminant ( $s$ )

- Fossils
- Changes in drilling methods or equipment

- Readings from detection equipment, if any

- Amount of water yield/ loss during drilling at different depths
- Arnounts and types of any Liquids used

- Running sands

- Caving/hole stability

Source: National Well Water Association 1986. 
the $317 / 319$ Area, continuous core samples should always be collected with a split-spoon sampler and recorded by a geologist in the field. Table 6 lists information that should be obtained during the drilling of well borings.

To reduce the number of potential migration pathways, the boreholes in which permanent wells are not constructed should be sealed with material at least 10 times less permeable than the surrounding media, in accordance with U.S. EPA and Illinols EPA procedures.

\subsubsection{Physical Laboratory Analyses}

Laboratory analyses should be performed on soil samples to provide information on petrologic variation (i.e., grain size distribution, sorting, and cementation), moisture content, and hydraulic conductivity for the till. These data will provide a basis for correlating the stratigraphy of individual borings, identifying zones of potentially high hydraulic conductivity, and determining the continuity of petrologic characteristics. Soil characteristics -- bulk density, particle density, total organic content, and porosity -should be measured to determine the potential for contaminant migration in the glacial till groundwater. Bulk density and porosity may be measure in situ using well logging techniques. Cementation, moisture content, and hydraulic conductivity should also be determined for the dolomite.

\subsubsection{Field Measurements}

A total of eight monitoring well clusters should be installed within the 317 Area fence and around the 319 Area landfill to more accurately define the vertical hydraulic gradient in each of the areas and to obtain discrete water samples from at least two depths at each location. Because so little is known about the dolomite aquifer in this area, wells should also be drilled to the dolomite bedrock at these locations to monitor water levels and potential contaminants. At each location, wells should be placed in closely spaced but separate boreholes. Figure 13 shows the proposed locations of the nested wells. Wells should not be drilled into the landfill area, but rather on its perimeter (Fig. 13). New wells may be coupled with existing wells 10 and 11 to form well nests. However, new wells packed with gravel over shorter intervals may be preferable. Because the subsurface geology has not been recorded for the northeast corner of the 317 Area and the monitoring intervals of wells 12 and 13 are unknown, it is recommended that one well nest be drilled in this area. Two nested wells should be located south of the $317 / 31.9$ Area to monitor possible contaminant plumes (identifled by soil gas analyses performed by ESH). One well nest should be located near the French drain at the 317 Area. Groundwater in this area analyzed by ESH shows high levels of a number of VOCs, including carbon tetrachloride and ketones. Since wells 4 and 7 have been con stently dry, they should be decommissioned and sealed. It is also recommended that wells 12 and 13 be sealed since no information is avallable on their construction and monitoring intervals. 


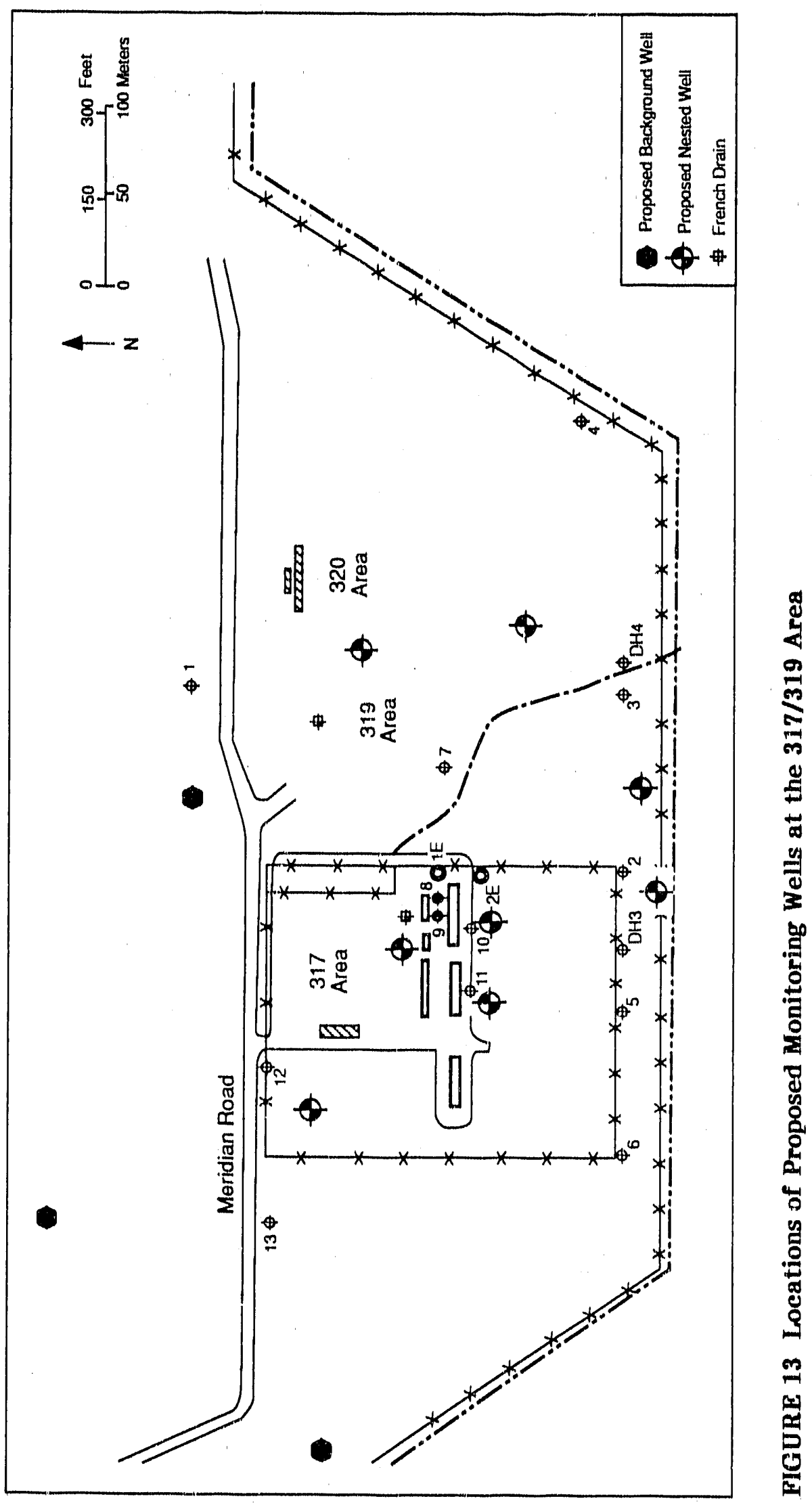


Hydraulio conductivity should be measured in the fleld by slug testing. This involves measuring water level changes after a solid teflon "slug" has been dropped into or removed from a well. A pressure transducer is placed into the well to sense ohanges in water level. Slug tests could be conducted in existing monitoring wells.

\subsubsection{Monitoring Program}

\subsubsection{Groundwater Monitoring}

To accurately define the shallow water table, new wells should be constructed in the first permeable water-bearing zone encountered during drilling. The bottom of the well should extend no more than $1.5 \mathrm{~m}$ ( $5 \mathrm{ft}$ ) below the watermbearing zone. To obtain useful, correlative data, it is important that water levels be measured for all wells within a 24-hour period (National Well Water Association 1986). For the monitoring of chemical specles in groundwater, it is desirable to sample discrete portions of a water-bearing formation. This can be accomplished by screening the well with screens $0.3-1.5 \mathrm{~m}$ (1-5 ft) long and extending the gravel pack no more than $0.3-0.6 \mathrm{~m}(1-2 \mathrm{ft})$ above the screen.

Because of the low hydraulic conductivity of the till in the $317 / 319$ Area, the zone of contamination, if present, is likely to be shallow and ro greater than a few feet thick. The U.S. EPA. (1989) recommends limiting the screen length to $0.3-0.6 \mathrm{~m}(1-2 \mathrm{ft})$ in areas with low conductivity to minimize siltation problerns as well as to eliminate possible dilution effects from water contributed by uncontaminated zones. The gravel pack should extend no more than a few feet above the screen. A quick sleve analysis in the field can be used to determine the correct screen and gravel-pack sizes to minimize siltation. Bentonite clay can then be extended from the gravel pack to within $0.6 \mathrm{~m}$ ( $2 \mathrm{ft}$ ) of the ground surface and a shrink-resistant, cement grout seal extenced to the ground surface. Appendixes $\mathrm{C}$ and $\mathrm{D}$ provide guidance on well design and construction.

Split-spoon samples should always be collected and logged by a geologist when a

new well is drilled. Selected samples should be collected at specifled intervals (depending on the well depth) and analyzed for suspected contaminants.

Most of the existing monitoring wells in the $317 / 319$ Area are cased with PVC. The lllinois EPA (1987) recommends that stainless-steel or teflon be used for the casing of wells used to monitor organic compounds (see App. C). Additionally, Illinois EPA regulations must be complied with to ensure that data collected from monitoring wells will be considered valid. Wells that do not conform to the state and federal protocols outlined in A.pps. $C$ and $D$, respectively, may be used during exploratory programs but not monitoring programs.

\subsubsection{Background Monitoring}

Figure 13 shows the locations of three proposed new control wells north and west of the 317 and 319 Areas. Since the groundwater flow is predominantly to the southeast, 
these wells should provide data representative of upgradient (background) conditions. Under U.S. EPA regulations [40 CFR 265.92(a)(1)], upgradient wells must be located and constructed in the same portion of the aquifer that is being monitored by downgradlent wells. Therefore, background wells should be completed in both the glacial till and dolomite bedrock. Since the direction of groundwater flow in the dolomite has not yet been established, it is recommended that the dolomite background well be installed after the monitoring wells are installed in the dolomite and water levels have been measured. To fully characterize the spatlal varlability of background water quality, it is recommended that more thar one background well be installed (National Well Water Association 1986). It is also recommended that use of well 1 as a control well be discontinued, since it is not truly upgradient from the site.

\subsubsection{Vadose Zone Monitoring}

To characterize the areal extent of VOC coritamination in the vadose (unsaturated) zone at the $317 / 319$ Area, discrete soll and soll-gas samples should be taken at $5-\mathrm{ft}$ intervals radiating away from each of the French drains (Fig. 13). Soll can be sampled directly using the core sampling method described in Dunlap et al. (1977). A soll gas survey can be conducted using gas probes that pump soil gas through an activated charcoal trap; gas is later desorbed from the trap for analysis by gas chromatography. The need for a long-term monltoring program will depend on the results of the initial sampling. 


\section{REFERENCES}

Berg, R.C., J.P. Kempton, and K. Cartwright, 1984, Potential for Contamination of Shallow Aquifers in Illinois, Illinois State Geological Survey Clroular 532.

Cheever, L., 1988, Plant Facilities and Services, Argonne National Laboratory, personal communication to R.H. Pearl.

Dunlap, W.J., et al., 1977, Sampling for Organic Chemicals and Microorganisms in the Subsurface, U.S. Environmental Protection Agency Report EPA-660/2-73-014, Corvallis, Oregon.

Freeze, R.A., and J.A. Cherry, 1979, Groundwater, Prentice-Hall Inc., Englewood Cliffs, N.J.

Golchert, N.W., and T.L. Duffy, 1989, Argonne National Laboratory - East Site Environmental Report for Calendar Year 1988, Argonne National Laboratory Report ANL-89/8, April.

Illinols EPA, 1987, Groundwater Monitoring Network, draft guidance, Division of Land Pollution Control, [llinols Environmental Protection Agency, Feb. 2.

Intech Consultants, 1987, Topographic Map - Building 317 Area, Argonne National Laboratory, Intech Consultants, Inc., Downers Grove, Ill.

Killey, M.M., and C.B. Trask, 1989, Geotechnical Site Investigation, 7-GeV Advanced Photon Source - Argonne National Laboratory, Illinols State Geological Survey, Feb.

Knowles, D.B., W.J. Drescher, and E.F. LeRoux, 1963, Ground-Water Conditions at Argonne National Laboratory, Illinois, 1948-1960, U.S. Geological Survey Water-Supply Paper 1669-0.

Moos, L.P., Environment, Safety, and Health Department, Argonne National Laboratory, personal communication to T.L. Patton.

National Well Water Association, 1986, RCRA Ground Water Monitoring Technical Enforcement Guidance Document (TEGD), National Water Well Association, Dublin, Ohlo, Sept.

U.S. EPA, 1989, Groundwater Handbook, U.S. Environmental Protection Agency, Washington, D.C., Jan.

Will County Well \& Pump Co., 1988, Invoice and Breakdown on the Four monitoring Wells Recently Drilled for ANL (knowr as the Dolomite Deep Wells), File No. 88-45EC-059, New Lenox, lll., Sept. 30.

Zelicel, A.J., et al., 1962, Groundwater Resources of DuPage County, Illinois, Illinois State Geologtoal Suryey Cooperative Groundwater Report 2. 


\section{APPENDIX A:}

\section{AVAILABLE WELL, INSTALLATION DIAGRAMS, DRILLERS' LOGS, AND GEOLOGISTS' LOGS FOR BORINGS IN THE 317/319 AREA}

This appendix presents all avallable records for monitoring wells and boreholes drilled in the $317 / 319$ Area from 1986 to 1989 . These records provided the basis for the analysis of subsurface geology at the area. Table A.1 lists the contents of this appendix. All well and borehole records were provided by ESH. 
TABLE A.1 Boring Diagrams and Logs Presented in Appendix A

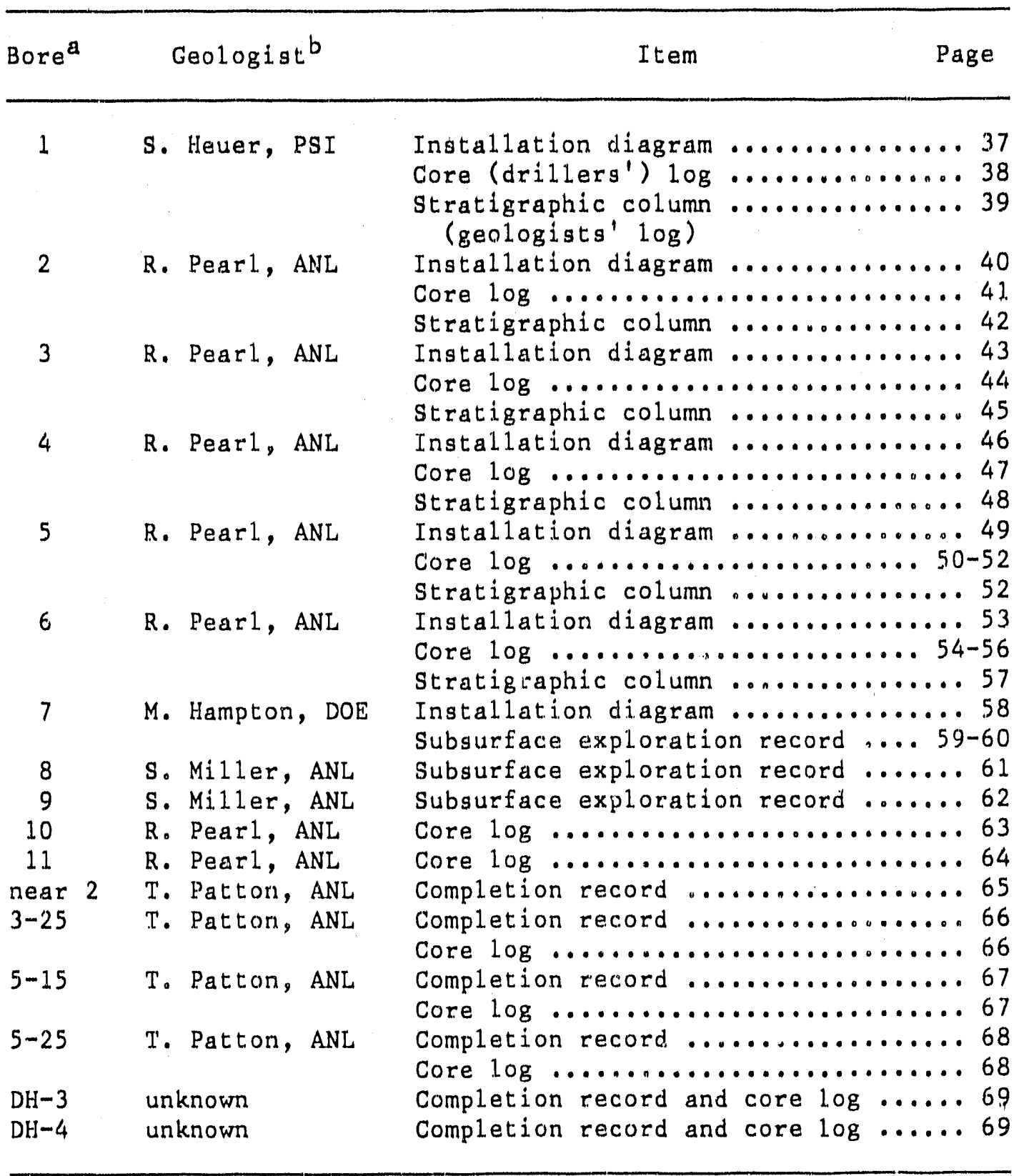

ancludes both monitoring wells and boreholes.

$b_{S}$. Heuer is affiliated with Professional Service Industries, M. Hampton with the U.S. Department of Energy Environmental Survey Team, S. Miller with ANL's cinergy Systems Division, T. Patton with ANL's Environmental. Assessment and Information Sciences Division (EID), and R. Pearl, currently with Eder and Associates, formerly with EID. 


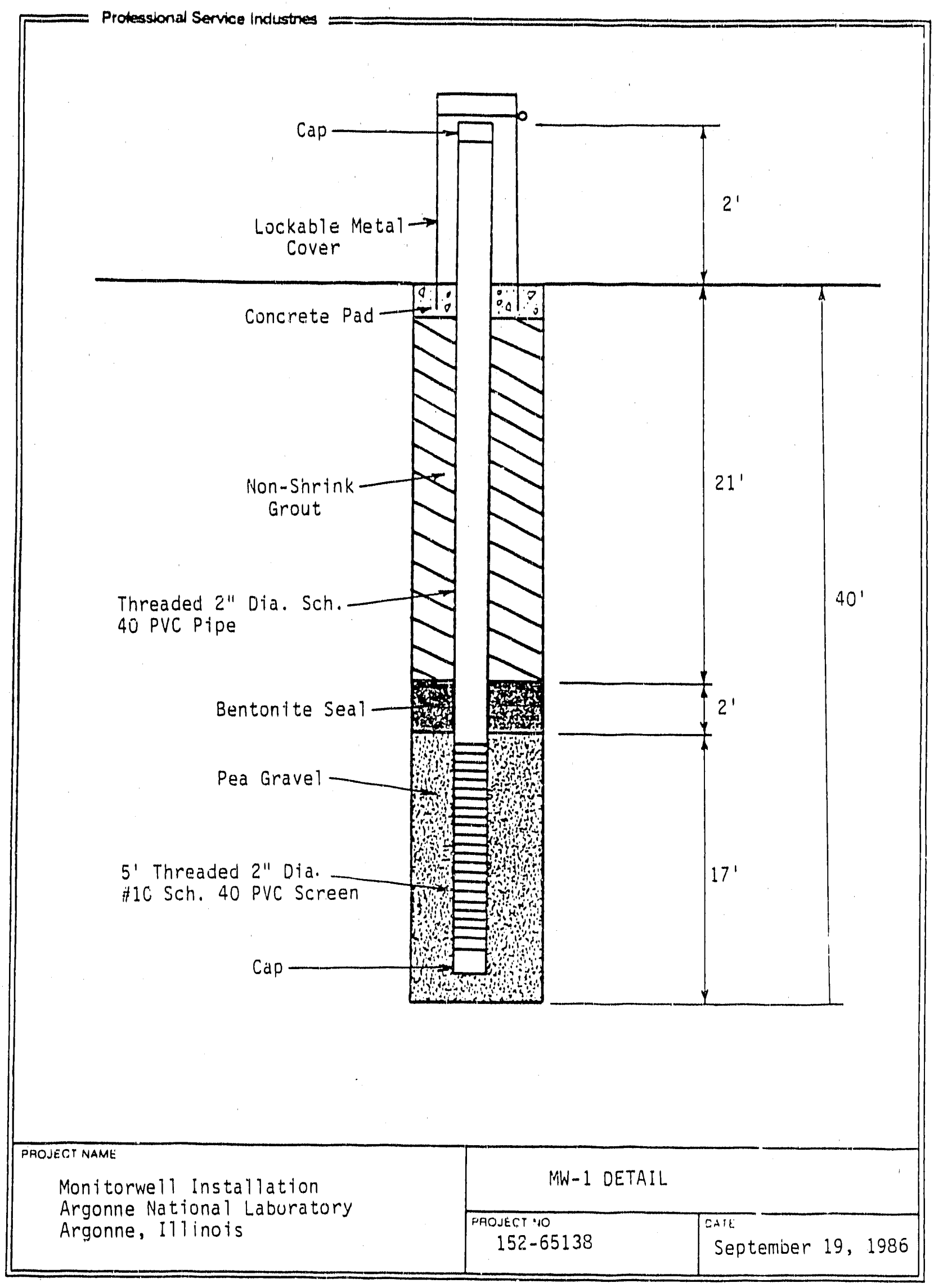


NEW WELL NO. 1 ( 300 Area)

SPLIT SPOON CORE LOG

Location: North of both the natural gas pipeline and rifle range, east of the radioactive waste storage area.

Date Drilled: Sept. 19, 1986

Total Depth: $40 \mathrm{ft}$.

Water level while drilling: $25 \mathrm{ft}$. approx.

10/8/86: $38.65 \mathrm{ft}$. below land surface.

Completion: Schedule 40 PVC blank casing and screen

$0-35 \mathrm{ft}$. blank casing $0-21 \mathrm{ft}$. grout

$35-40 . \mathrm{ft}$ screen

21 - $23 \mathrm{ft}$, bentonice

23 - $40 \mathrm{ft}$. pea gravel

Geologist: S. Heuer, PSI

Depth Description

(ft)

0 - 1 Soil, dark brown silty clay, moist

1 - 2 Silt, clayey, tan and gray, very hard, moist. Contains medium to coarse sand and occasional iron stains.

$2 \quad 4$ As above.

4 - 6 As above

6 - 7 As above

7 - 8 Clay, silty, brown, moist with medium to coarse sand.

8 - 9 As above

9 - 10 Sand and gravel seam

10. - $11.5 \mathrm{Clay}$, silty, brown, moist with thedium to coarse sand

11.5 - 12 Clay, silty, gray, moist, with medium to coarse sand

$12-14$ As above

$14-16$ As above

$16-18$ As above

$18-18.5$ As above

18.5 - 19.5 Sand, coarse to medium with some coarse gravel, Wet

19.5 - 20 Clay, silty, gray, moist

20. -20.5 As above

20.5 - 21.5 Silt, brown moist, contains limestone fragments.

21.5 - 22 Clay, silty, gray, moist with brown medium to coarse sand seams and Iimestone gravel Eragments.

$22-24$ As above

$24-26$ As above. Wet at $25 \mathrm{ft}$.

$26-28$ As above

$28-30$ As above

$30-32$ As above

$32-34$ As above

$34-36$ As above

36 - 38 As above

$38-40$ As above

40 Total Depth. 
NEW WELL NO. 1 (300 Area)

STRATIGRAPHIC COLUMN

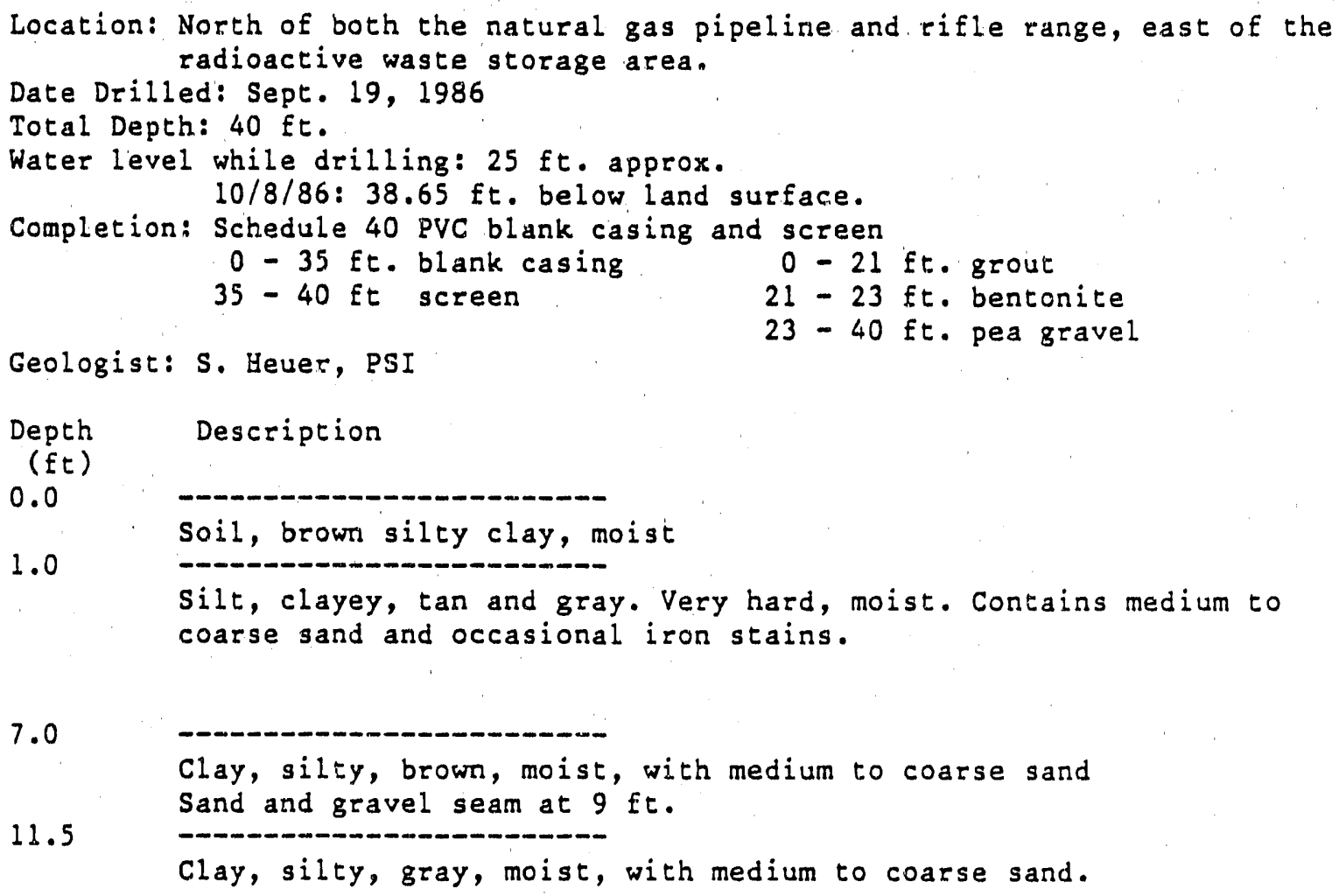

7.0

Clay, silty, brown, moist, with medium to coarse sand Sand and gravel seam at $9 \mathrm{ft}$.

11.5

Clay, silty, gray, moist, with medium to coarse sand.

18.5

Sand, coarse to medium, with some coarse gravel. Wet

19.5

Clay, silty, gray, moist

20.5

Silt, brown, moist, with limestone fragments.

21.5

Clay, silty, gray, moist, with brown medium to coat'se sand seams and limestone gravel fragments. Wet at $25 \mathrm{ft}$.

35 .

Silt, gray, moist, with coarse limestone gravel fragments.

40. Total Depth 


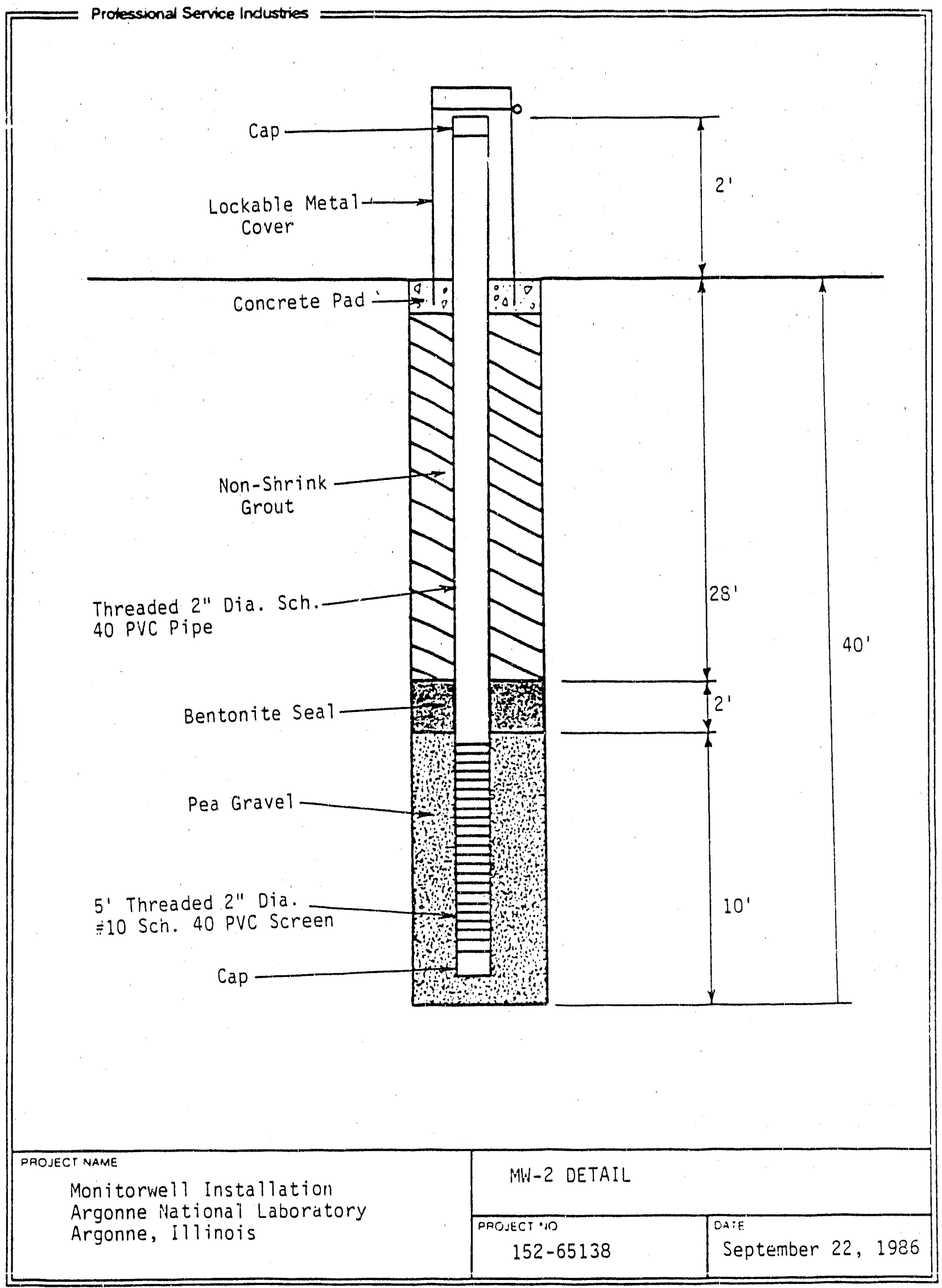


MONITORING WELL \#2 (300 Area)

SPLIT SPOON CORE LOG

Location: SE corner of 317 area

Date Drilled: Sept. 19, 1986
Total Depth: $40 \mathrm{ft}$.

Water Level while drilling: 17.5 ? Et. 10/8/46: $31.42 \mathrm{ft}$. below land surface

Completion: Schedule 40 PVC blank casing and screen

Geologist: R. H. Pearl, ANL

$\begin{aligned} 0 & -26 \text { ft grout } \\ 26 & -28 \text { ft Bentonite } \\ 28 & -40 \text { ft Pea Gravel }\end{aligned}$

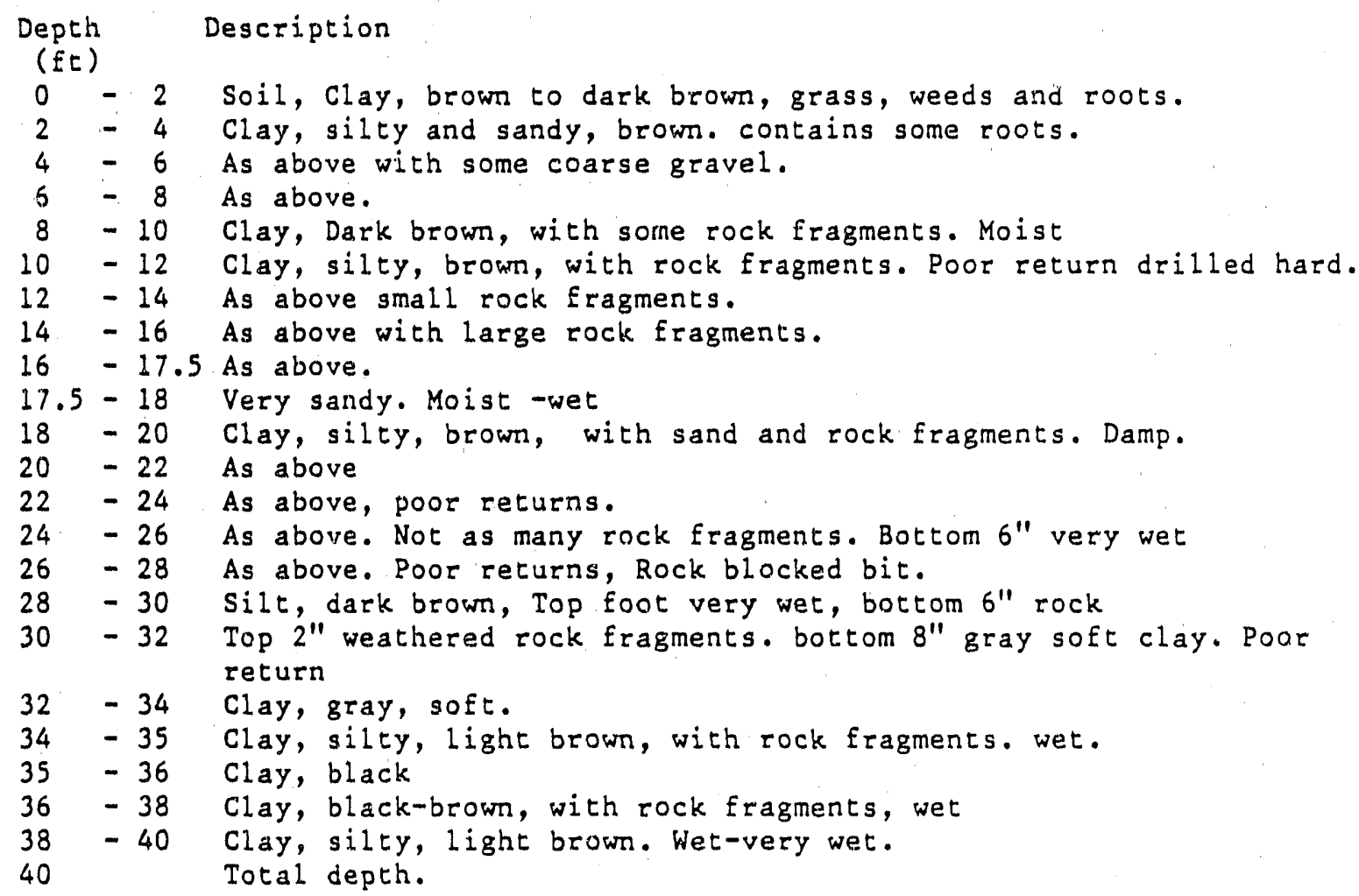


MONITORING WELL 非 (300 Area)

STRATIGRAPHIC COLUMN

Location: SE corner of 317 area.

Date Drilled: Sept. 19, 1986

Completion: Schedule 40 PVC blank casing and screen
Total Depth: $40 \mathrm{ft}$.

Water Level while drilling: 17.5? ft.

10/8/86: $31.42 \mathrm{ft}$. below land surface

\begin{abstract}
0 - 35 ft. blank casing
35 - $40 \mathrm{ft}$. screen
\end{abstract}

Geologist: R. H. Pearl, ANL

Depth

0.0

4

17.5

18

25.5

Clay, brown, silty, very wet

29.5

31.3

35

38

40

Very sandy, moist-wet

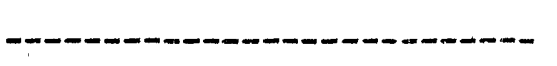

Rock fragments, weathered

-

Clay, gray, soft

Total depth
Description

Soil, Clay, brown silty. Grass, Weeds, roots

Clay, brown silty, Contains some sand, gravel and rock fragments. Moist $\begin{aligned} 0 & -26 \text { ft grout } \\ 26 & -28 \text { ft Bentonite } \\ 28 & -40 \text { ft Pea Gravel }\end{aligned}$

Clay, brown, silty, damp. Contains sand and rock fragments.

Clay, silty, light brown. with rock fragments. WET.

Clay, silty, light brown, wet-very wet. 


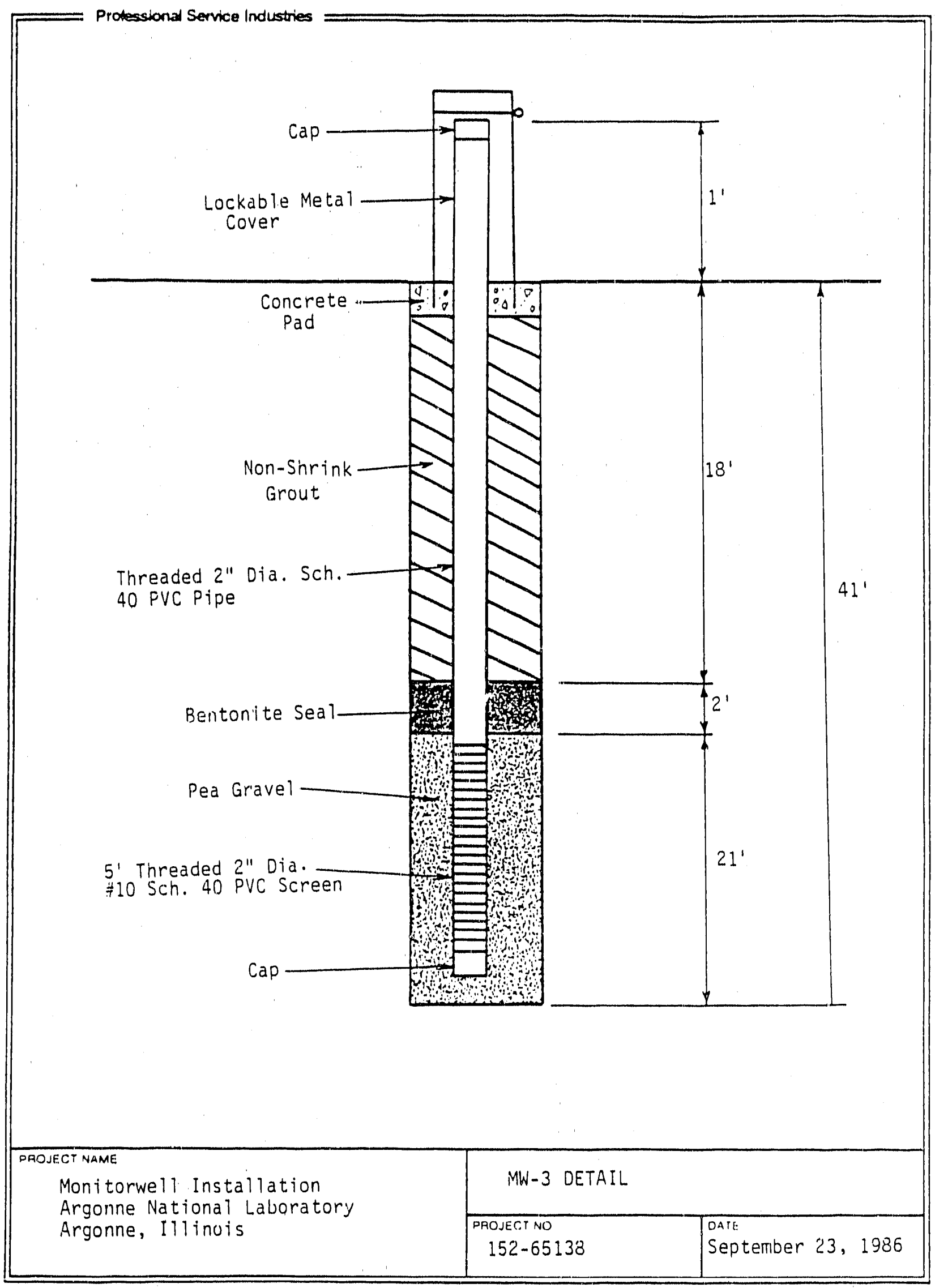


MONITORING WELL 非3 (300 Area)

SPLIT SPOON CORE LOG

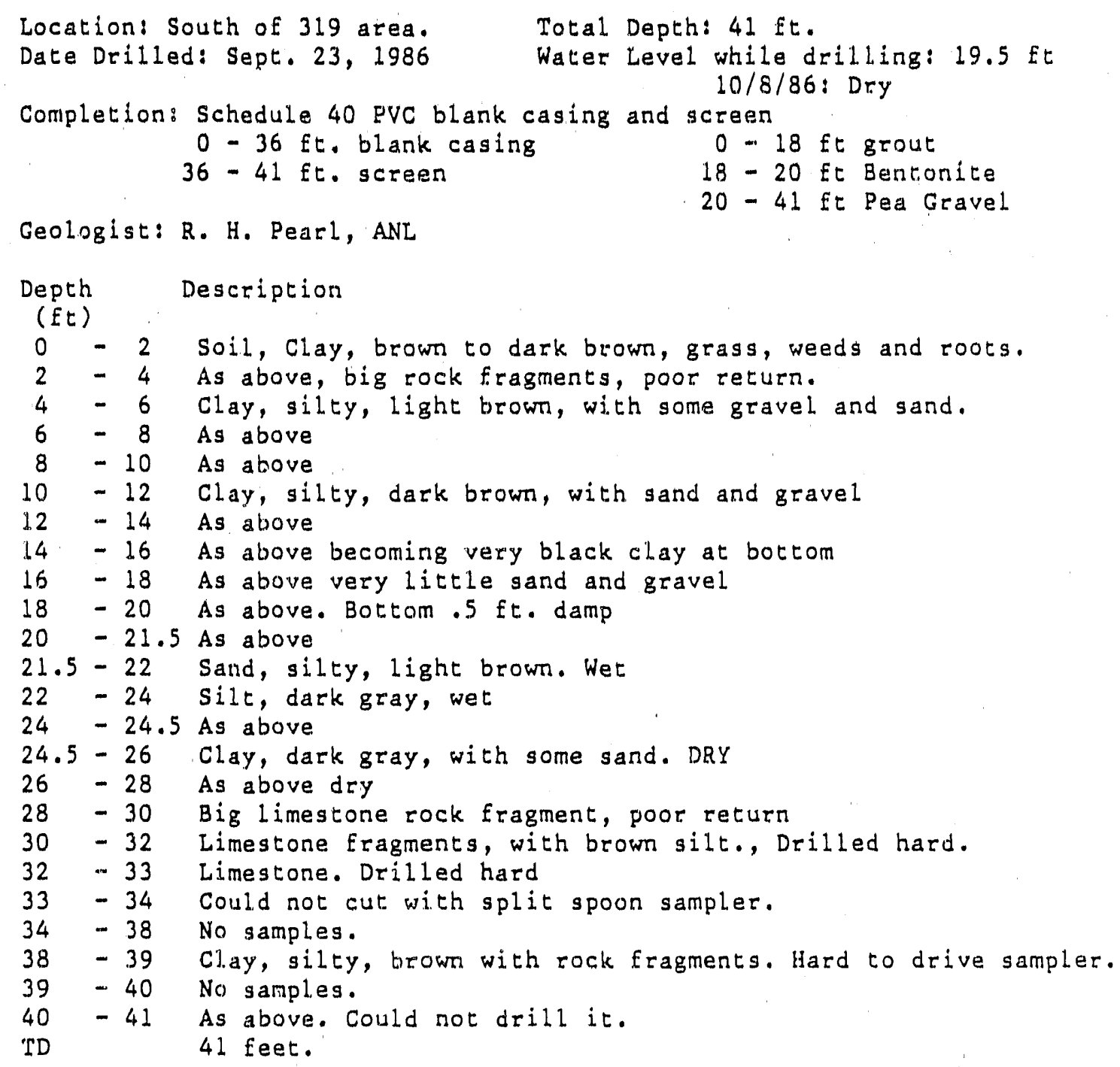




\section{MONITORING WELL \#3 (300 Area)}

STRATIGRAPHIC COLUMN

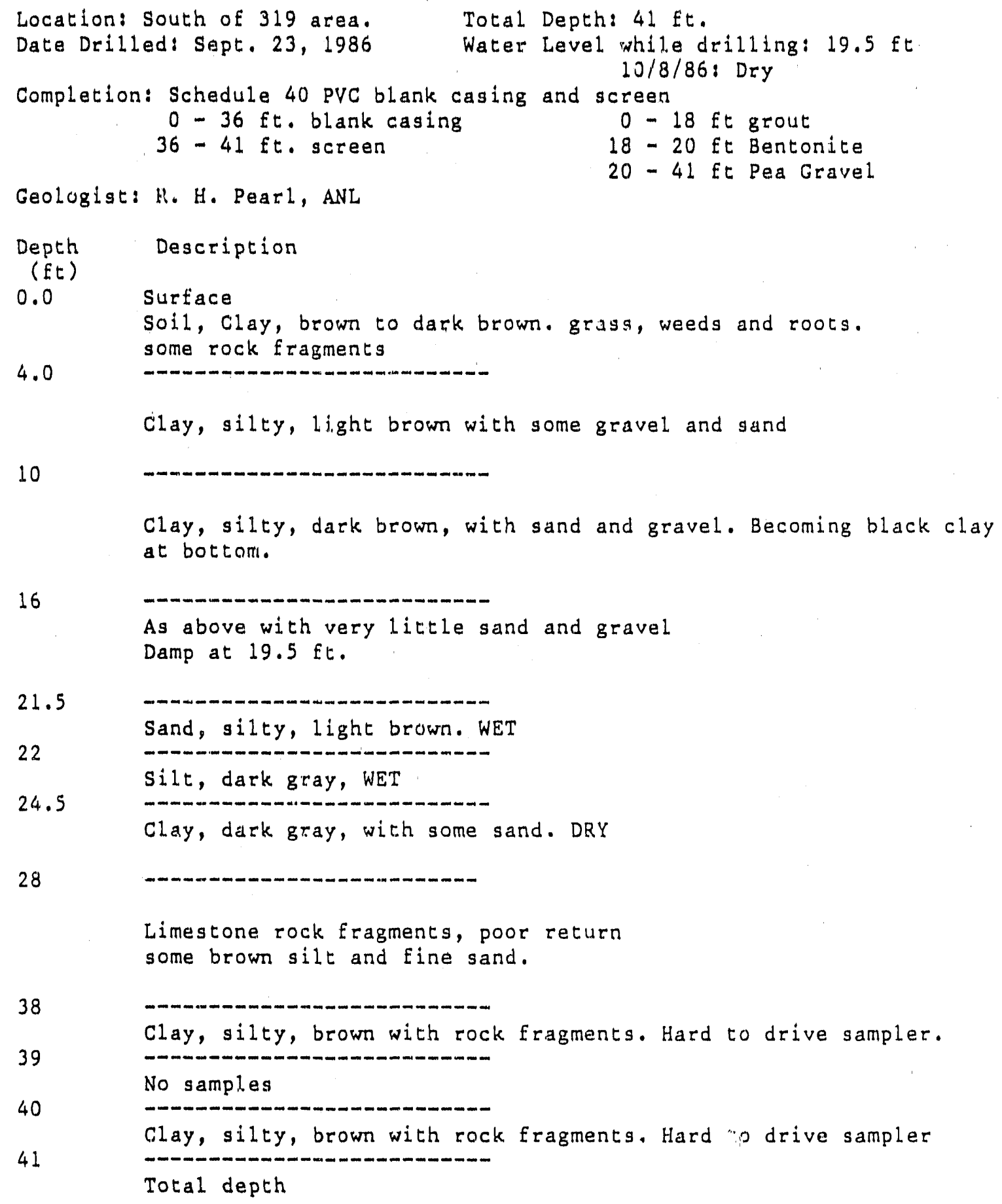




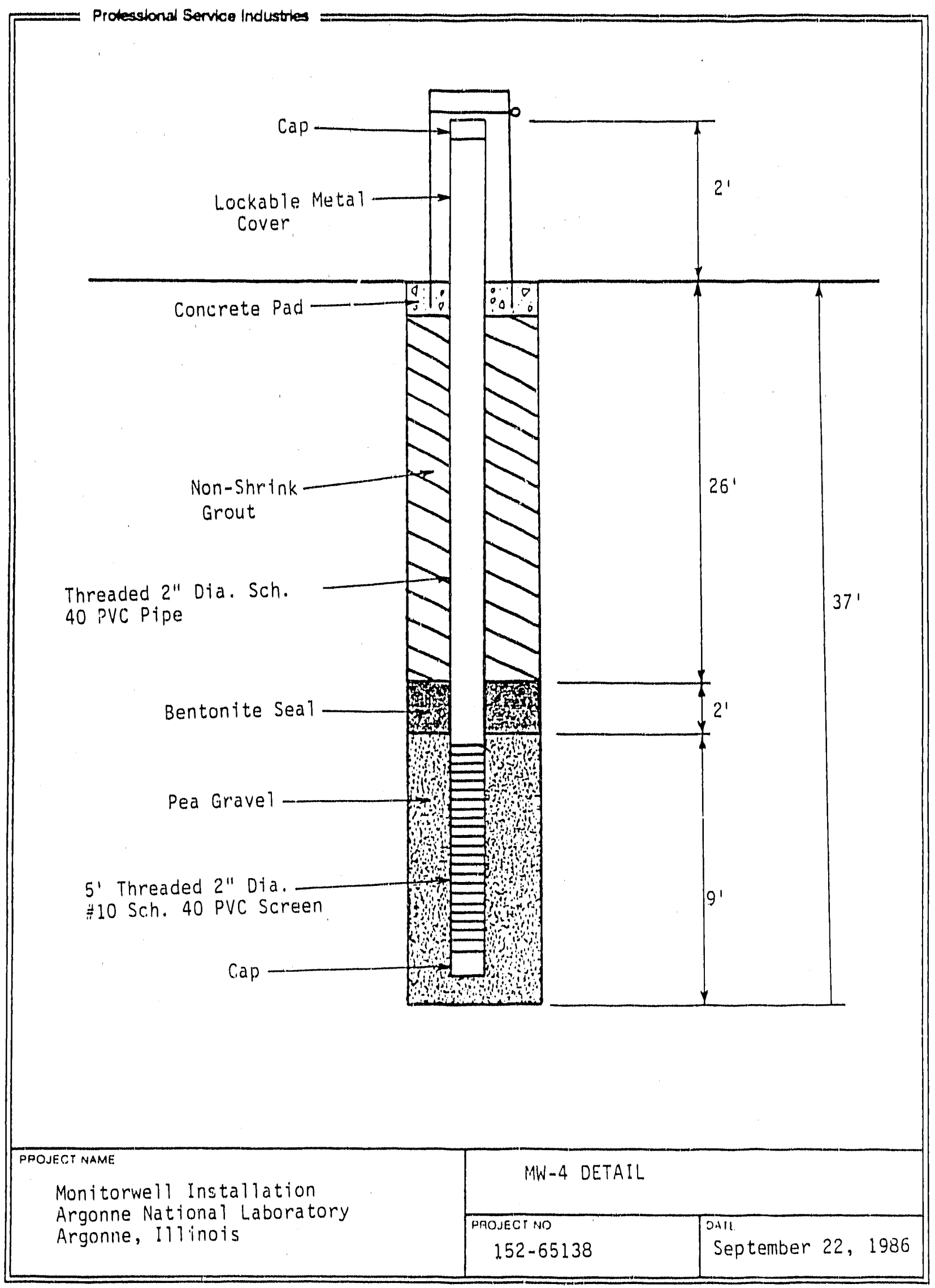


MONITURING WELL \#4 (300 ArEa)

SPLIT SPOON CORE LOG

Location: East of 319 area.

Total Depthi $37 \mathrm{ft}$.

Date Drilled: Sept. 22, 1986

Water Level while drilling: Dry

$10 / 8 / 86: d r y$

Completion: Schedule 40 PVC blank casing and screen

0 - 32 Et. blank casing

$32-37 \mathrm{ft}$. screen

$0-28$ Et grout

28-30 Bentonite

30-37 Pea Gravel

Geologigt: R. H. Pearl, ANL

Depth Description

(Et)

0 - 2 Soil, dark brown clay, roots

$2-3$ As abova

3 - 4 Brown silty clay, hard

4 - 6 Brown silty clay, hard, with some small gravel, some yellow iron staining.

$6-8$ Sample missing

$8-8.5$ As above

$8.5-10$ Brown silty sand, wet

$10-12$ Brown and gray clay with some gravel, moist

$12-14$ As above

14 - 16 As above grading into black clay at bottom

$16-18$ Black clay with some gravel

$18-20$ As above, not as much gravel

$20-22$ As above

$2.2-24 \quad$ As above

24 - 26 As above, poor return

$26-28$ As above, good return

$28-29.3$ As above

29.3 - 30 Light brown sand with some gravel and sith

$30-32$ As above, big limestone fragments. Poor return, drilled hard

$32-34$ Broken Limestone fragments, sandy

$34-35.5$ As above

$35.5-36 \quad$ Brown siley clay

36 - 37 Weathered limestone, clayey. Split spoon sampler would not go any further.

Total Depth $37 \mathrm{ft}$. 


\section{MONITORING WELL \#4 (300 Area) \\ STRATIGRAPHIC COLLMN}

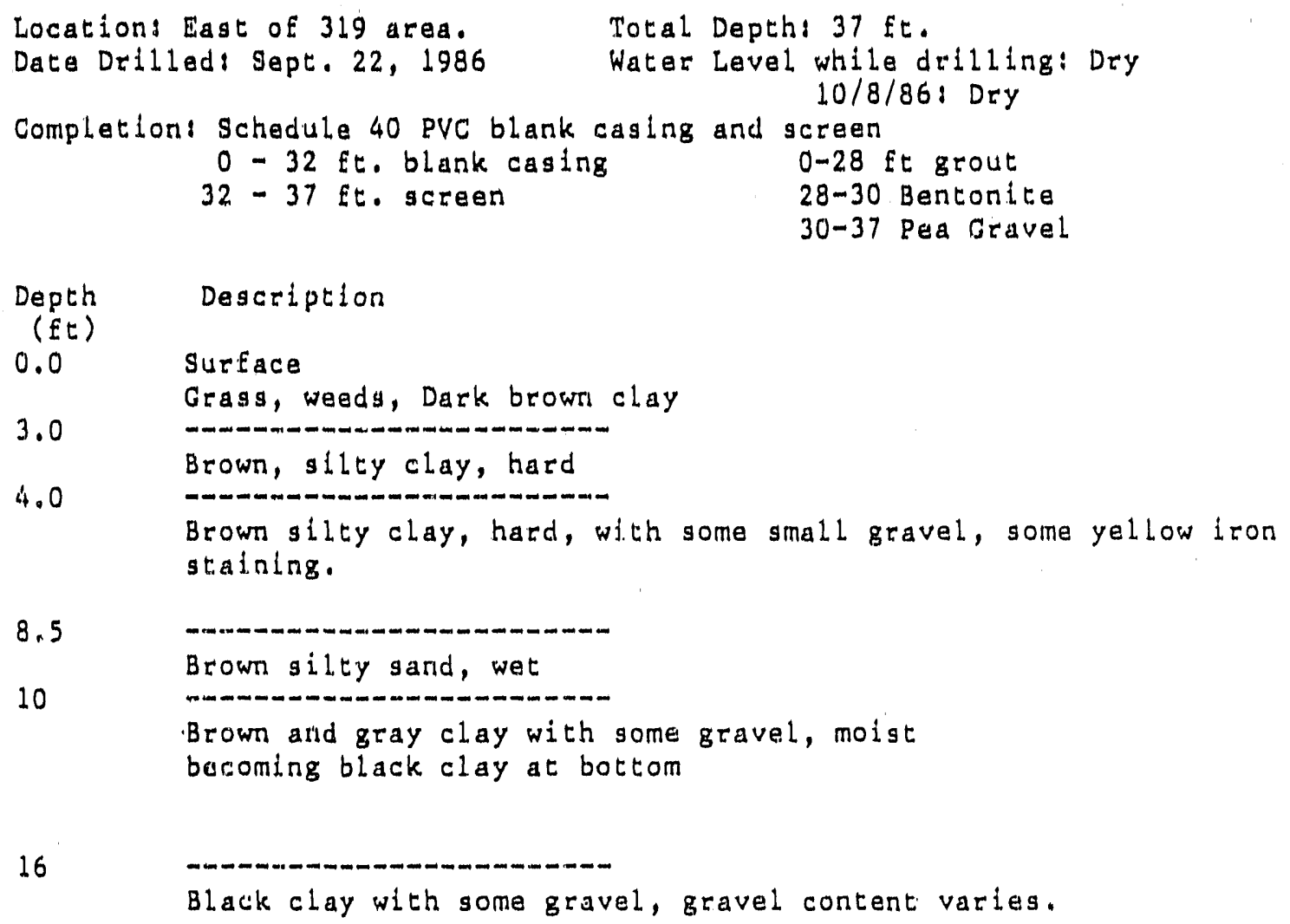

29.3 


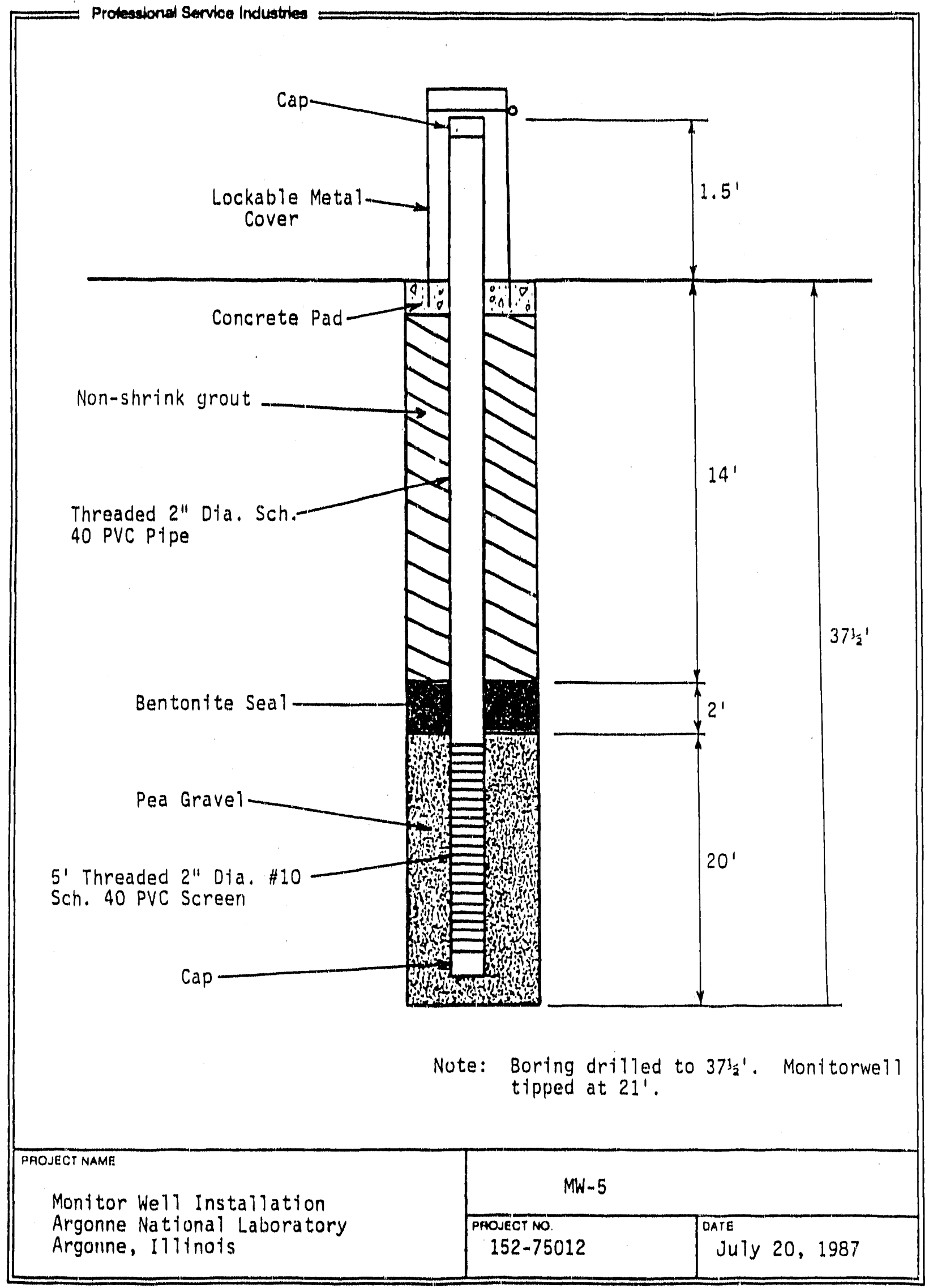




\section{MONITORING WELL NO. 5 (317 AREA)}

Location:

Date Drilled:

Total Depth:

Water Level:

Completion:

Geologist:

R.H. Pearl, ANL July 20,1987

36 feet
Approximately in middle of south tence line around 317 storage area.

while drilling; $9.3 \mathrm{ft}$ (approx.), and others commencing at $20 \mathrm{ft}$.

$12.53 \mathrm{ft} .(7 / 21 / 87)$

$16.00 \mathrm{ft} .(7 / 25 / 87)$

19.50 ft. $(8 / 5 / 87)$

Schedule 40 PVC blank casing and screen. +2.0 - 2 ft. blank steel protective casing +1.7 - 15.5 ft. blank casing

$15.5-20.5 \mathrm{ft}$. screen

$0-2$ it cement

$2 \cdots 12$ Et. grout

$12-14$ ft. bentonite

$14-20.5$ ft. sand

Drilling commenced at approximately 9:40 a.m. July 20, 1987 and ceased at approximately $2: 30 \mathrm{p} . \mathrm{m}$. The well was drilled to a total depth of 36 feet. Due to the nature of the subsurface geological materials (see below $\log$ ) it was very diffleult to accurately determine the water bearing zones. A $4 \mathrm{ft}$. thick zone was encountered at an approximate depth of $9.3 \mathrm{ft}$. Other cuestionable water bearing zones were encountered starting at about $20 \mathrm{ft}$ and extending to the bottom of the nole. We attempted to complete this well using the same procedure used in 1986, i.e, the auger flights are pulled and the screen and casing placed into the hole. However, when the screen and casing were placed in the hole it was found that the hole had collapsed below a depth of $20.5 \mathrm{ft}$. As water was standing in the hole above the collapsed zone it was decided to complete the well at this depth rather than trying to redrill the hole. There is some question regarding this well. When PSl attempted to develop the well on August 5 th the water level was found to be very near the bottom of the well. As noted earlier due to completion methods it was not possible to accurately determine the depth to the top of the sand pack or bentonite plug and the water bearing zones may have been sealed off accidentally.

\section{SPLIT SPOON CORE LOG}

\section{Depth (ft.) Description}

$00.0-1.5 \quad$ Length of split spoon sample recovered: $1.0 \mathrm{ft}$. Brown silty clay with some gravel and organic material.

1.5 - 3.0 Length of split spoon sample recovered: N.M. Brown silty clay with rusty streaks

3.0-4.5 Length of split spoon sample recovered: $1.0 \mathrm{ft}$. Gray-brown silty and clay, drilled hard 


\author{
4.5 - 6.0 Length of split spoon sample recovered: $1.2 \mathrm{ft}$. \\ Gray-brown silt and clay, with some gravel. Drilled hard. \\ $6.0-7.5$ Length of split spoon sample recovered: $0.2 \mathrm{ft}$., poor recovery. \\ Clay, dark brown. \\ 7.5 - 9.0 Length of split spoon sample recovered: $1.2 \mathrm{ft}$. \\ Clay, dark brown, with some gravel. Damp. \\ 9.0 - 10.5 Length of split spoon sample recovered: 1.2 \\ Brown silty clay with some sand. \\ 9.3 - $9.6 \mathrm{ft}$. Medium-coarse sand lense \\ All moist-wet. \\ 10.5 - $12.0 \quad$ Length of split spoon sample recovered: $0.7 \mathrm{ft}$. \\ Sand and fire gravel, wet \\ $12.0-13.5 \quad$ Length of split spoon sample recovered: $0.0 \mathrm{ft}$. \\ Wet core barrel. \\ Auger cuttings at surface not very wet. \\ $13.5-15.0 \quad$ Length of split spoon sample recovered: $1.5 \mathrm{ft}$. \\ Gray plastic silt and clay with some gravel. \\ $15.0-16.5$ Length of split spoon sample recovered: $0.8 \mathrm{ft}$. Rock fragment at \\ bottom. \\ $16.5-18.0$ \\ $18.0-19.5$ \\ Gray plastic silt and clay with some gravel. \\ Length of split spoon sample recovered: $0.3 \mathrm{ft}$. poor recovery \\ Gray plastic silt and clay with some gravel and large limestone rock \\ fragments. \\ Length of split spoon sample recovered: $0.5 \mathrm{ft}$ \\ Gray plastic silt and clay, slightly damp. \\ $19.5-21.0 \quad$ Length of split spoon sample recovered: $0.9 \mathrm{ft}$. \\ Top 2" wet gray plastic clay \\ Gray clay grading to hard dry brown clay with some gravel pleces. \\ Outside of split spoon wet. \\ $21.0-22.5 \quad$ Length of split spoon sample recovered: $0.4 \mathrm{ft}$. \\ Gray plastic clay with sand and gravel. Rock fragment at base of \\ sample. \\ Wet auger cuttings to surface. \\ 22.5 $-24.0 \quad$ Length of split spoon sample recovered: 0.7 ft. \\ Brown sandy silt, wet. \\ Drilled very hard, Rock?? \\ 24.0 $-25.5 \quad$ Length of split spoon sample recovered: $1.5 \mathrm{ft}$. \\ Brown sandy silt with sand and gravel \\ Top 6" wet. \\ $25.5-27.0 \quad$ Length of split spoon sample recovered: $0.5 \mathrm{ft}$. \\ Brown silty clay with large rock fragments. \\ Drilled like in rocks and gravel.
}


$27.0-28.5$

Length of split spoon sample recovered: $0.7 \mathrm{ft}$.

Wet sample at top.

Cored very hard.

Broken limestone ( $\left.8^{\prime \prime}\right)$, weathered, sandy.

Not much trouble drilling out hole.

$28.5-30.0 \quad$ Length of split spoon sample recovered: $0.9^{\prime}$ approx.

Drilled very very hard.

More weathered limestone and gravel

$0.2 \mathrm{ft}$ thick black silty clay at base.

$30.0-31.5 \quad$ Length of split spoon sample recovered: $0.0 \mathrm{ft}$.

Outside of spoon very wet

Drilled very hard.

31.5-33.0 Length of split spoon sample recovered: 0.0

Drilled hard

$33.0-34.5$

Length of split spoon sample recovered: $1.3 \mathrm{ft}$

Sampler drove easily

Gray silty clay with some sand and very small gravel, damp.

$34.5-36.0 \quad$ Length of split spoon sample recovered: N.M.

Gray silty clay with some sand and very small gravel.

T.D. 36.0

MONITORING WELL NO. 5

STRATIGRAPHIC COLUMN

Depth (ft)

\section{Description}

0.0

Surface

1.5

Soil, brown silty clay, moist, roots and grass.

3.0

Clay, brown silty, with rusty streaks

9.3

Clay, gray-brown, silty, with some gravel, drilled hard

9.0

10.5

??

Sand, Medium-coarse, wet

Clay, gray-brown, silty; with some sand and gravel

Sand and fine gravel, wet

13.5

Silt and Clay, gray, plastic with some gravel

22.5

Some gravel and large limestone rock fragments

Silt, sandy, brown and gray, wet

with some sand and gravel zones

with some large rock fragments.

Total Depth 


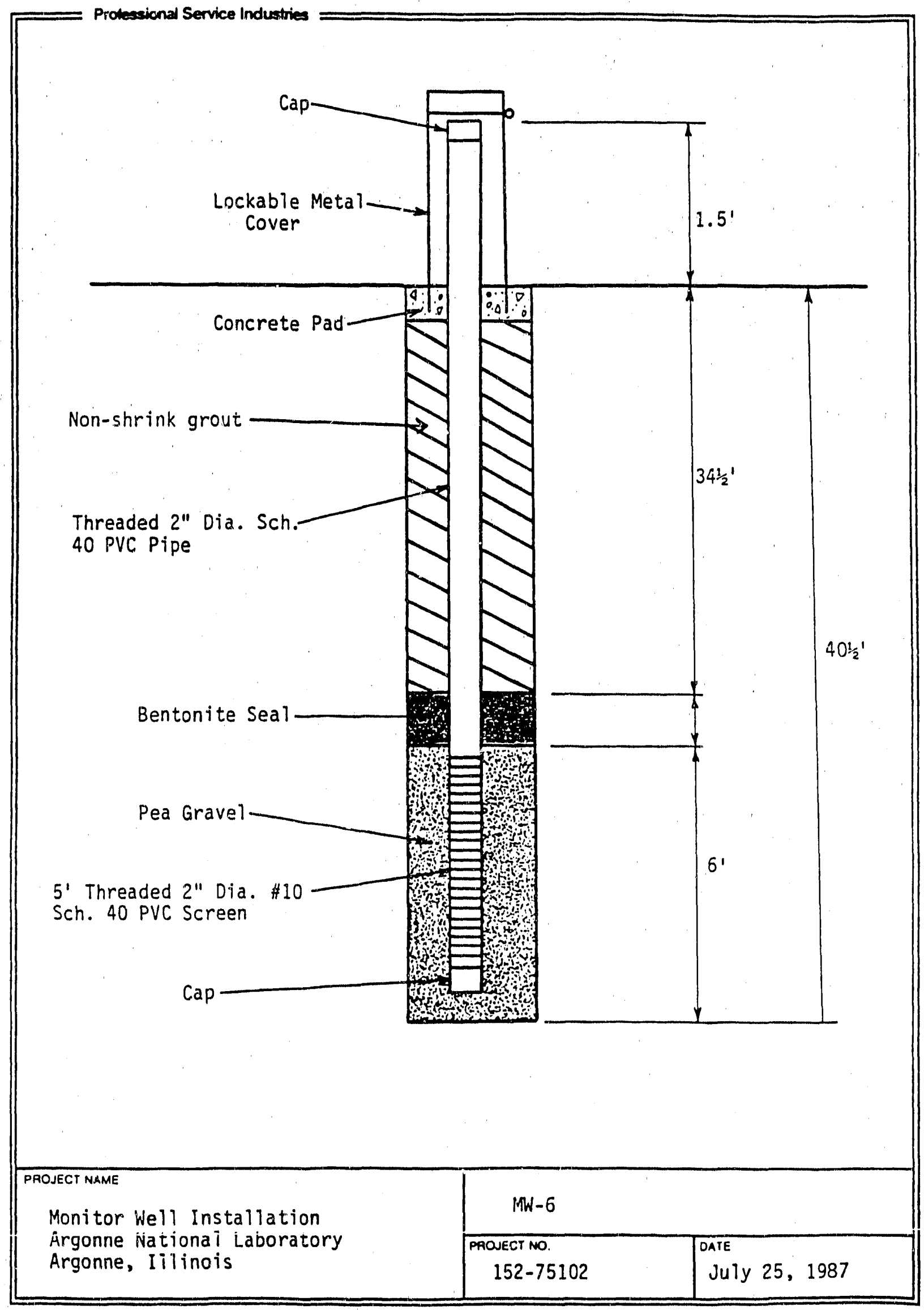


MONITORING WELL NO. 6 (317 AREA)

Location: Date Drilled: Total Depth: Water level:

Completion:
SW corner of 317 ares. Commenced $7 / 21 / 87$, finished $7 / 25 / 87$. Well developed $8 / 5 / 87$. $40 \mathrm{ft}$. while drilling; $10.5 \mathrm{ft}$ approximately $12.5 \mathrm{ft} .(7 / 25 / 87)$ $27.57 \mathrm{ft}(8 / 5 / 87)$

Schedule $\$ 0$ PVC blank casing and screen. $+0.0-2$ Blank protective steel casing $+1.0-35 \mathrm{ft}$. blank casing $\quad 0-2 \mathrm{ft}$. (approx.) cement $35-40 \mathrm{ft}$. screen $2-31 \mathrm{ft}$. (approx.) grout $31-33$ ft. (approx.) bentonite 33 - 40 ft. (approx.) sand

Geologist:

R.H. Pearl, ANL

Drilling commenced at approximately 10:00 p.m. and ceased at approximately 3:00 p.m. 7/21/87. Driller was unable to pull auger flights from hole. Attempted to pump water down hole but water pump was broken. Left auger flights in hole and returned to shop to have pump repaired. Returned on $7 / 25 / 87$ and completed well. Well completed using following hollow auger stem method: Screen and blank casing installed inside the hollow auger stem to bottom of hole; approx. $2 \mathrm{ft}$. of fine silica sand then poured down the inside of the hollow auger stem and outside of the casing; the auger flights pulled up and the process repeated until the height of sand was approximately two feet above top of screen level. Bentonite slurry then emplaced in a similar manner. Upon completion of emplacing the bentonite slurry the remaining auger flights were removed from the hole and the hole filled with a cement grout. Due to the lack of space between the casing and the auger it was not possible to measure the depth tis the top of the sand or bentonite seal. PSI personnel returned on 8/5/87 and developed the well by bailing it dry.

\section{SPLIT SPOON CORE LOG}

Drilling log

Depth (ft)

$0.0-1.5$

$1.5-3.0$

$3.0-4.5$

$4.5-6.0$

$6.0-7.5$

$7.5-9.0$

\section{Description}

Length of split spoon sample recovered: $1.0 \mathrm{ft}$. Brown and gray silty clay with roots.

Length of split spoon sample recovered: $1.2 \mathrm{ft}$. Brown and gray silty clay with some fine gravel.

Length of split spoon sample recovered: $1.5 \mathrm{ft}$.. Brown and gray silty clay with some fine gravel.

Length of split spoon sample recovered: $1.5 \mathrm{ft}$. Brown and gray silty clay with some fine gravel.

Length of split spoon sample recovered: $1.5 \mathrm{ft}$. Rrown and gray silty clay with dark red rusty streak at bottom.

Length of split spoon sample recovered: $0.2 \mathrm{ft}$. Brown and gray silty clay. 


\section{MONITORING WELL $\$ 6$ \\ SPLIT SPOON CORE LOG (CONT.)}

Depth (ft)

$9.0-10.5$

$10.5-12.0$

$12.0-13.5$

$13.5-15.0$

$15.0-16.5$

$16.5-18.0$

$18.0-19.5$

$19.5-21.0$

$21.0-22.5$

$22.5-24.0$

$24.0-25.5$

$25.5-27.0$

\section{Description}

Length of split spoon sample recovered: $1.5 \mathrm{ft}$.

$9.0-10.3 \mathrm{ft}$. Brown and gray silty clay with dark red rusty streak. $10.3-10.5 \mathrm{ft}$. Fine gravel to fine sand, rusty.

Length of split spoon sample recovered: $1.5 \mathrm{ft}$. $10.5-11.0 \mathrm{ft}$. Brown clay with some gravel $11.0-12.0 \mathrm{ft}$. Black to gray plastic clay.

Wet auger cuttings to surface.

Length of split spoon sample recovered: $1.5 \mathrm{ft}$.

Black to gray plastic clay, moderately wet, with some gravel and sand.

Length of split spoon sample recovered: $1.5 \mathrm{ft}$.

Black to gray plastic clay, with some gravel and sand.

Length of split spoon sample recovered: $1.5 \mathrm{ft}$.

Black to gray plastic clay, with some gravel and sand. Damp but not wet.

Length of split spoon sample recovered: $1.5 \mathrm{ft}$.

Black to gray plastic clay, with some gravel and sand. Damp but not wet.

Length of split spoon sample recovered: $1.5 \mathrm{ft}$.

Black to gray plastic clay, with some gravel and sand. Damp but not wet.

Length of split spoon sample recovered: $1.5 \mathrm{ft}$.

Black to gray plastic clay, with some gravel and sand. Darnp but not wet.

Length of split spoon sample recovered: $1.5 \mathrm{ft}$.

Black to gray plastic clay, with some gravel and sand. Damp but not wet.

Length of split spoon sample recovered: $0.5 \mathrm{ft}$.

Black to gray plastic clay, with some gravel and sand. Damp but not wet.

Length of split spoon sample recovered: $0.5 \mathrm{ft}$.

Black to gray plastic clay, with some gravel and sand. Damp but not wet.

Length of split spoon sample recovered: $1.5 \mathrm{ft}$.

Blow counts up from 26 to $33 \mathrm{~b} / 12$ "

Black to gray plastic clay, with some gravel and sand. Damp but not wet.

Split spoon sampler very wet.

Water level at $20 \mathrm{ft}$ below surface af ter standing for approx. 2 hours. 


\section{MONITORING WELL 6 \\ SPLIT SPOON CORE LOG (CONT.)}

Depth ( $\mathrm{ft})$

$27.0-28.5$

$28.5-30.0$

$30.0-31.5$

$31.5-33.0$

$33.0-34.5$

$34.5-36.0$

$36.0-37.5$

$37.5-39.0$

\section{Description}

Length of split spoon sample recovered: $1.5 \mathrm{ft}$.

Black to gray plastic clay, with some gravel and sand. Damp but not wet.

Spoon contained water when opened.

Length of split spoon sample recovered: $1.0 \mathrm{ft}$.

Black to gray plastic clay, with some gravel and sand. Damp but not wet.

Very hard to break sample.

Length of split spoon sample recovered: $1.5 \mathrm{ft}$.

Black to gray plastic clay, with lots of gravel and sand. Gravel layer at base.

Length of split spoon sample recovered: $0.3 \mathrm{ft}$.

Black to gray plastic clay with lots of gravel and sand. Limestone rock fragments.

Length of split spoon sample recovered: $0.7 \mathrm{ft}$.

Sand and gravel with some clay.

Some rock fragments.

Split spoon barrel very wet on outside.

Blow counts way up

Very wet auger cuttings to surface -- soup. Driller said they came

from up the hole. I have my doubts about this.

Leng th of split spoon sample recovered: N.D.

Sand and gravel with some clay

Split spoon barrel contained lots of water.

Length of split spoon sample recovered: $1.2 \mathrm{ft}$.

$36.0-36.5 \mathrm{ft}$. gravel as above

$36.5-37.5$ gray to black clay with some gravel.

Length of split spoon sample recovered: $0.7 \mathrm{ft}$.

Gray to black clay with some gravel.

Drilled to $40 \mathrm{ft}$. Sampled to $39 \mathrm{ft}$. 


\title{
MONITORING WELL 6 (317 AREA) STRATIGRAPHIC COLUMN
}

\author{
Location: $\quad$ SW corner 317 area \\ Date drilled: July 21,1987 \\ Total Depth: $\quad 40 \mathrm{ft}$. \\ Water level while drilling: \\ Completion: Schedule 40 PVC blank casing and screen \\ Geologist: R.H. Pearl, ANL \\ Depth(ft) Description \\ $0.0 \quad$ Surface \\ Soil, Clay, brown to dark brown, grass, weeds, and roots. Some rock \\ fragments. \\ 1.5 \\ Clay, silty, brown and gray with some fine gravel. \\ 10.3 \\ Rusty streaks $7.5-10.3 \mathrm{ft}$. \\ 10.5 \\ Gravel and fine sand, rusty \\ 11 \\ Clay, brown with some gravel \\ Clay, black to gray, plastic, hard to break \\ with some sand and gravel \\ damp but not wet \\ 31.5 \\ Gravel layer, thin. \\ Clay, black to gray, plastic, with lots of sand and gravel, limestone \\ rock fragments. \\ 36.5 \\ Sand and gravel, with some clay and rock fragments \\ 39 \\ 40 \\ Clay, gray to black with some gravel \\ Total Sampled Depth \\ Total Drilled Depth
}


DOE sIte mine: ARGoove

VELC. 10 MURBER:

MELL CDORDIHATES aP MELL LOCATION: $3 / 4$ APQD

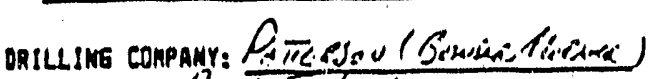
TYPE OF RIG: LAMtLTAL

aAte imstallatyon Conpleted (dd/ama/ryi: 0 EIDESIE"

TOTAL DEPTH: 43

$$
\begin{aligned}
& \text { DEVELOPMENT }
\end{aligned}
$$

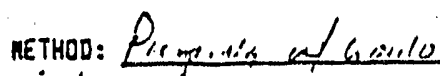

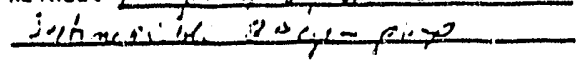

$$
\begin{aligned}
& \text { START DATE: } 2910 \leq 51 E 2 \\
& \text { IIME: } L \perp \text { : } L \\
& \text { ENO DATE: } \leq Q .10 \underline{0} \leq 1 \underline{2} \\
& \text { IIME: } \mathbb{L} \perp: \alpha \overline{0}
\end{aligned}
$$
( ) Clear
(I) slightly cloudy

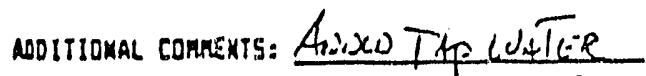
In Bevteute to cossite ferth

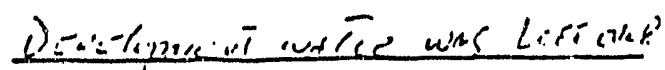

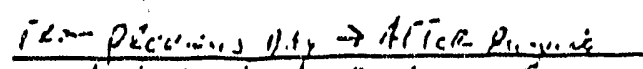

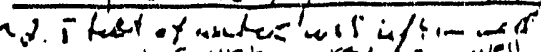
2,3 feet of wates wosy? well aECORDED ar: lilline Atro i to.- isignaturel c.8.0. an. 81

HELL CONSTRUCIYOM SUARARY

Then cenerison: it.
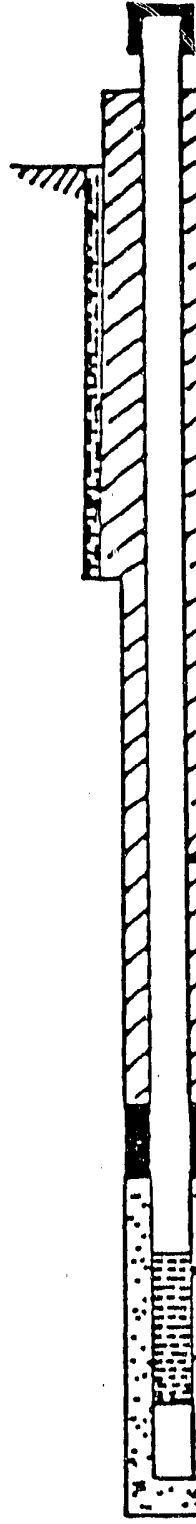

ELVATIOU: it.

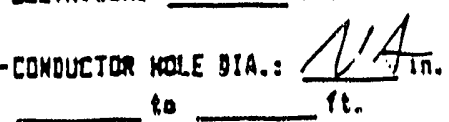

SURFACE CONOUCTOR TYPE: 10: ${ }_{\text {to }}^{\text {in. } 00:-T_{1 t}}$ in.
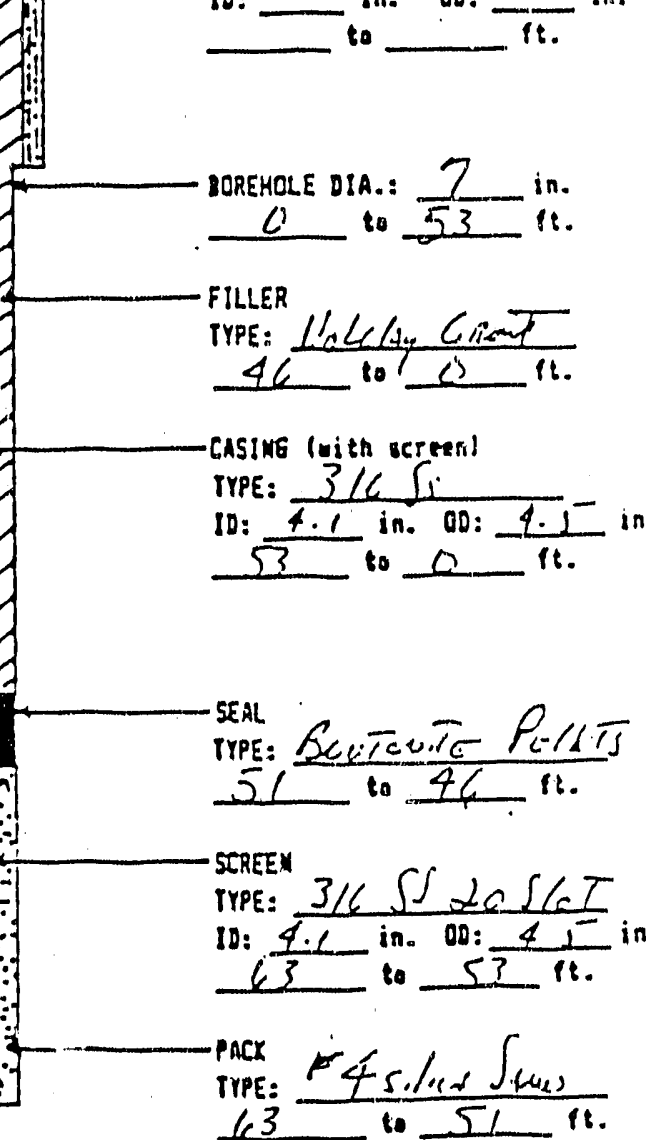
DOE EMUIRONMENTAL SURVEY

RECORD OF SUBSUAFACE EXPLORATION

DOE SITE MAME: Ak'ivivit

Pare 1 of 2

WELL ID MMMBER:

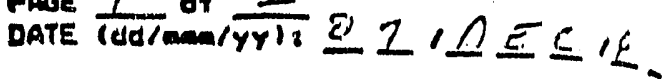

WELL COORDINATES ON DRILLING LOCATION: 319 , AREA

GROUND HATER FIRST ENCOUNTERED AT ti.

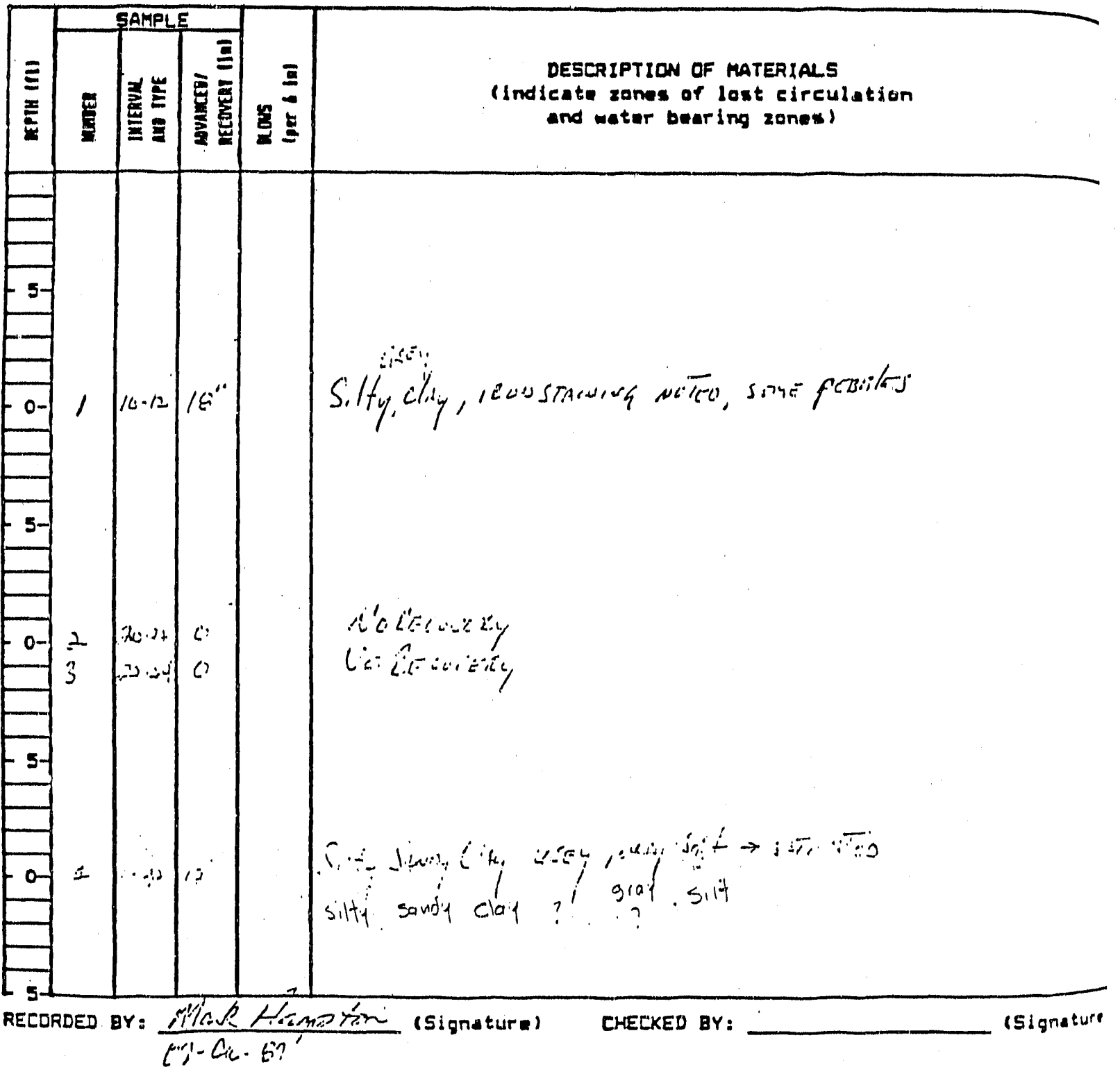


60

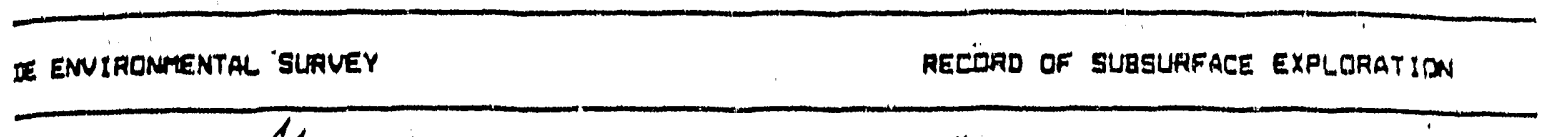

E STTE Mare: Alailulic

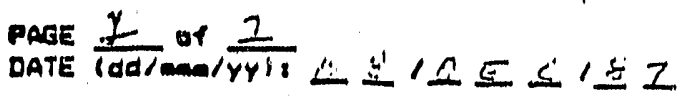

al io MuMgen: 7

WL coOrdinates or DRILLING Location: $3 / 4$ AELia

DUND HATER FIRST ENCOLNTERED AT _-

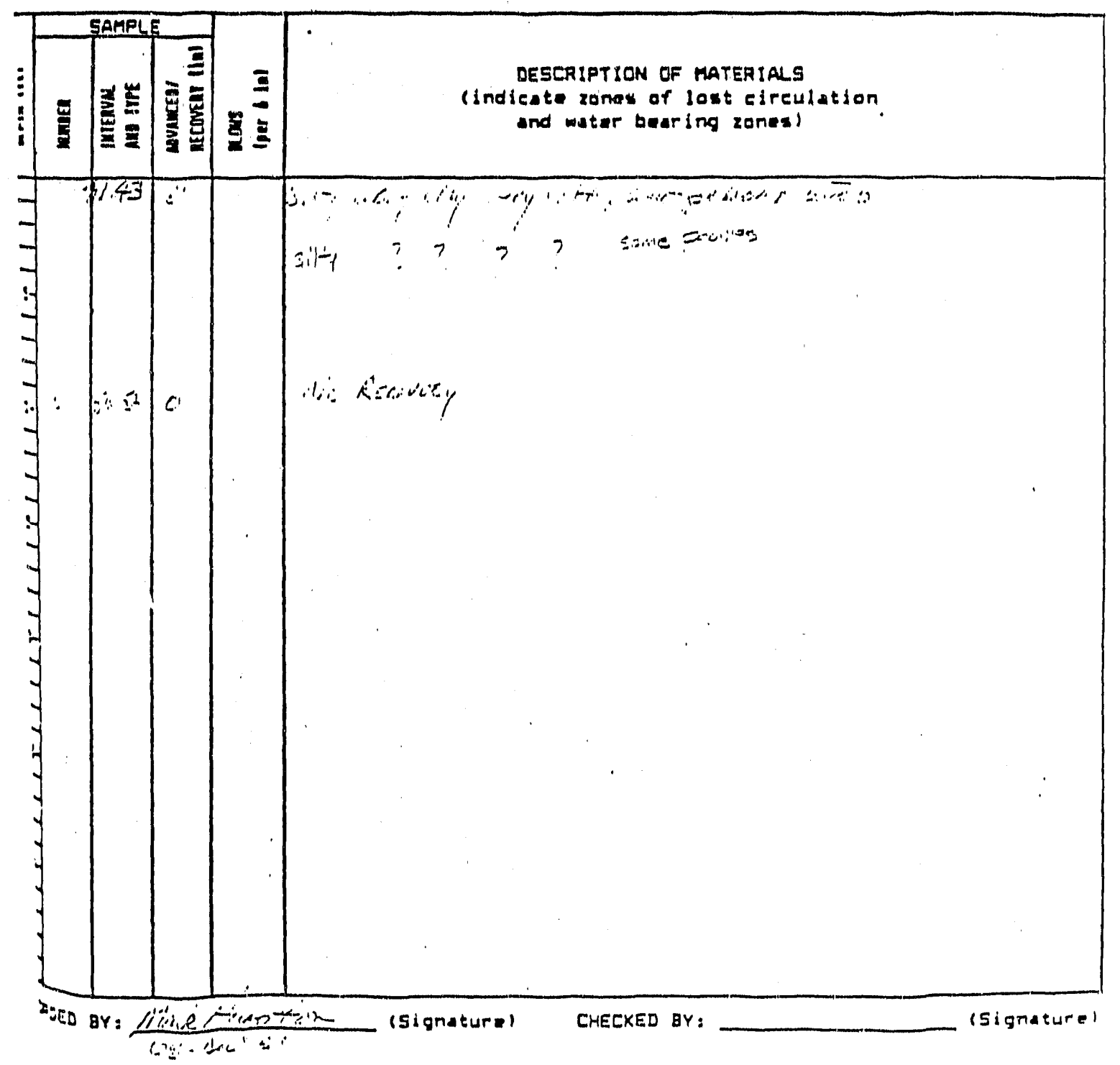


RECORD OF SUGSURFACE EXPLOAATION

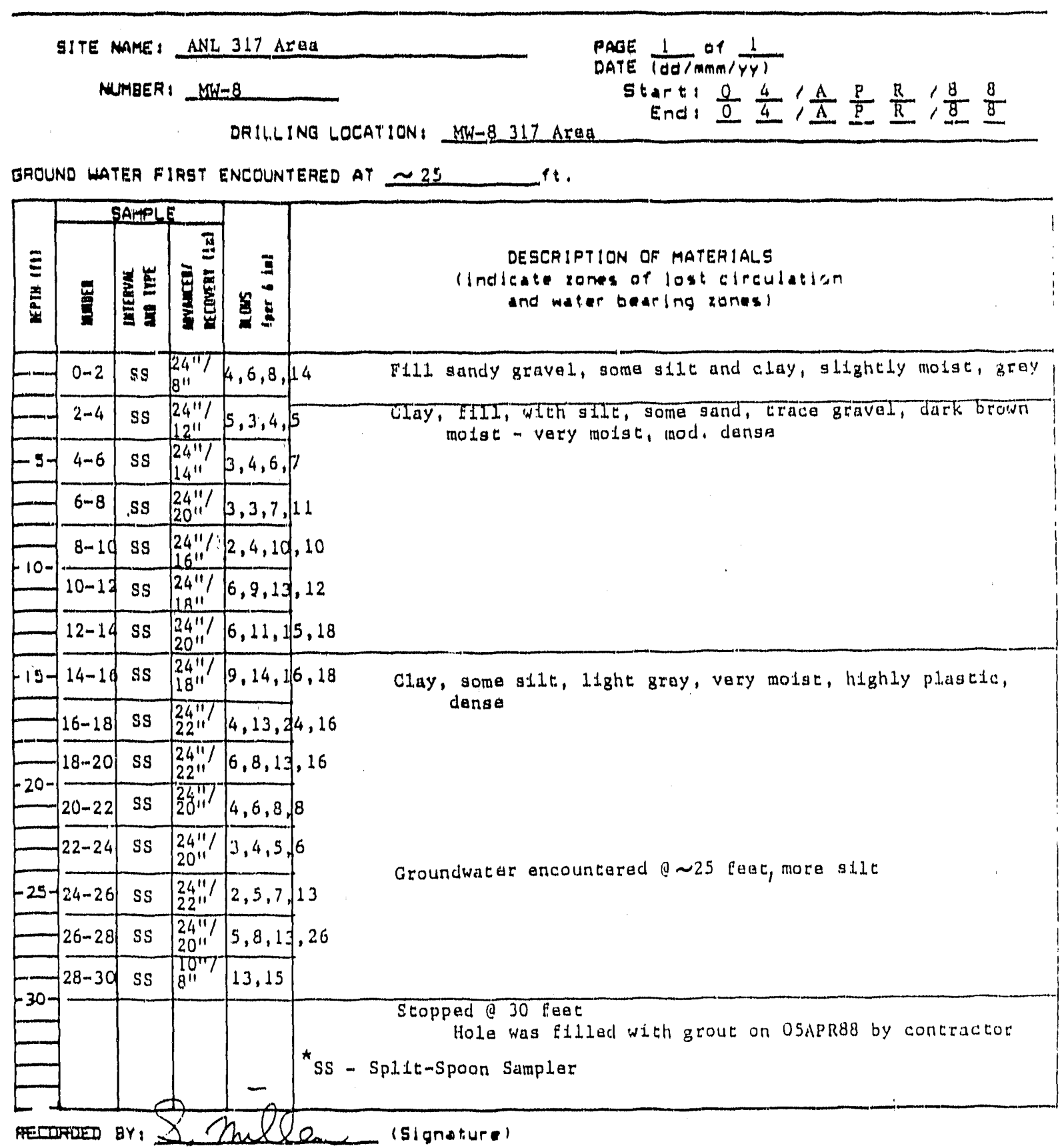


RECORD OF SUGGURFACE EXPLORATION

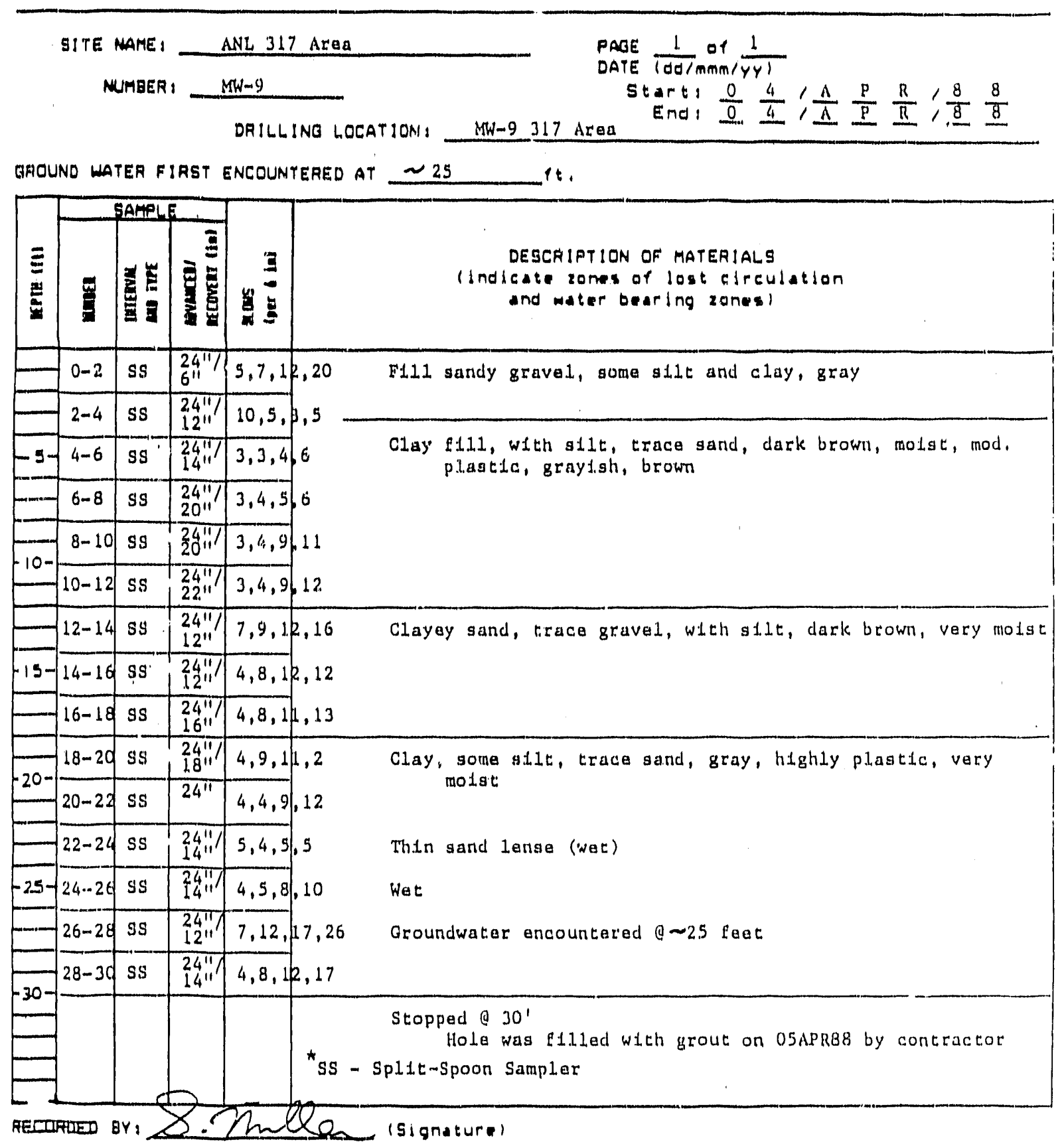




\section{Monitoring Well \#10}

\section{Well Complution Record}

Looation: About $20 \mathrm{ft}$ south and $50 \mathrm{ft}$ east of the sump between south vaults. Date Drilled: July 12, 1988

Total Depth: $30.5 \mathrm{ft}$ below land surface

Water Level While Drilling: about $13 \mathrm{ft}$ below land surface

Completion: $\quad 0-20.5 \mathrm{ft}$ - blank casing

$20.5-30.5 \mathrm{ft}$ - No. 10 screen

$0-5 \mathrm{ft}$ - cement grout

(2-in. OD casing and screen)

$5-7 \mathrm{ft}$ - bentonite clay

30.5-7 ft - pea gravel

Geologist: R.H. Pearl, ANL

\section{Soll Description}

Depth (ft)

Description

0 - 5 Brown clay, silt, with some sand and gravel, dry, drilled easy.

5 - 10 As above, becoming more damp with depth. Formed clay balls.

$10-15$ As above. Sand lens at 13-15 ft. Water. Samples very wet and roupy.

$15-20$ Black clay and silt with some sand and gravel. Samples very wet.

$20-25$ No samples, drilled moderately hard. Very rough drilling at about 24.5 ft may have been a gravel lens.

25 - 30.5 Light brown. Cuttings thin and muddy. Lots of water. 


\section{Monitoring Well \#11}

\section{Well Completion Record}

Location: About $20 \mathrm{ft}$ south and $50 \mathrm{ft}$ west of the sump between south vaults. Date Drilled: July 12, 1988

Total Depth: $30.5 \mathrm{ft}$ below land surface

Water Level While Drilling: about $13 \mathrm{ft}$ below land surface

Completion: $\quad 0-20.5 \mathrm{ft}$-blank casing

20.5-30.5 ft - No. 10 screen

$0-5 \mathrm{ft}$ - cement grout

(2-in. OD casing and screen)

5-7 ft - bentonlte clay

$30.5-7 \mathrm{ft}$ - pea gravel

Geologist: R.H. Pearl, ANL

\section{Soll Description}

Depth (ft)

\section{Description}

0 - 5 Light brown clay, silt with some sand and gravel, dry.

5 - 8 As above. Samples getting damp with depth.

8 - 13 Sand and gravel. Rocks up to 3 inches in diameter.

13 - 15 Dark gray silt and clay, wet. Water.

$15-20$ As above.

$20-25$ As above. 21-22 drilled very rough, may have been a gravel layer.

$25-30.5 \quad$ Poor returns. Light brown silt and clay, very wet. 


\section{WELL COMPLETION RECORD}

\section{WELL NEAR MW-e ( 317 Area)}

Location: Approximately $10 \mathrm{ft}$ west of MW-2, 317 area Date Drilled: August 11, 1989

Total Depth: $14 \mathrm{ft}$

Water Level While Drilling: DRY

Completion: Bottom 5 ft of hole was filled with bentonite, remainder was filled with bore hole material.

Geologist: T.L. Patton, ANL 
NEW WELL MW-3-25 (317 Area)

Location: Approximately b $f t$ west of $M W-3,31.7$ area

Date Drilled: August 10, 1989

Total Depth: $25 \mathrm{ft}$

Water Level While Drilling: $22 \mathrm{ft}$

Completion: Schedule 40 PVC threaded blank casing and screen

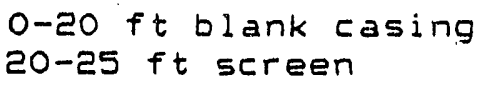

Geologist: T.L. Patton, ANL

\section{SOIL DESCRIPTION}

Location: Approximately o ft west of well MW-3, 317 area Date Drilled: August 10, 1989

Total Depth: $25 \mathrm{ft}$

Water Level While Drilling: Approximately 2 e ft

Completion: Schedule 40 pVC blank casing and screen

$$
\begin{aligned}
& 0-20 \text { ft blank casing } \\
& \text { 20-25 ft screen }
\end{aligned}
$$

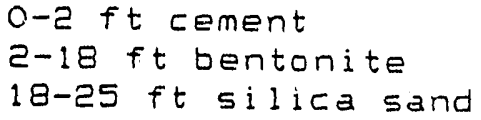

Geologist: T.L. Patton, ANL

Depth ( $f t) \quad$ Description

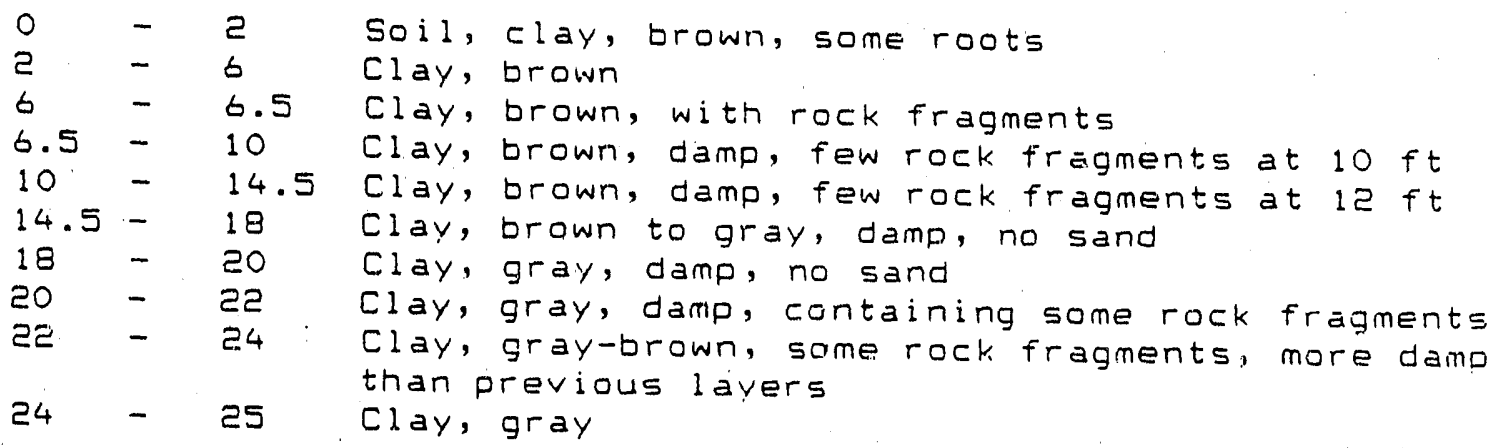




\section{REPLACEMENT WELL MW-5-15 (317 Area)}

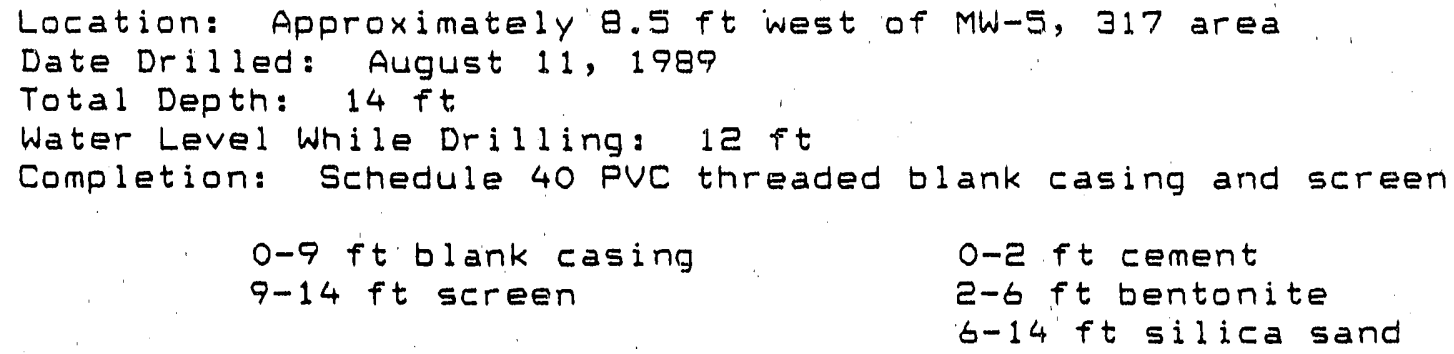

Geologist: T.L. Patton, ANL

\section{SOIL DESCRIPTION}

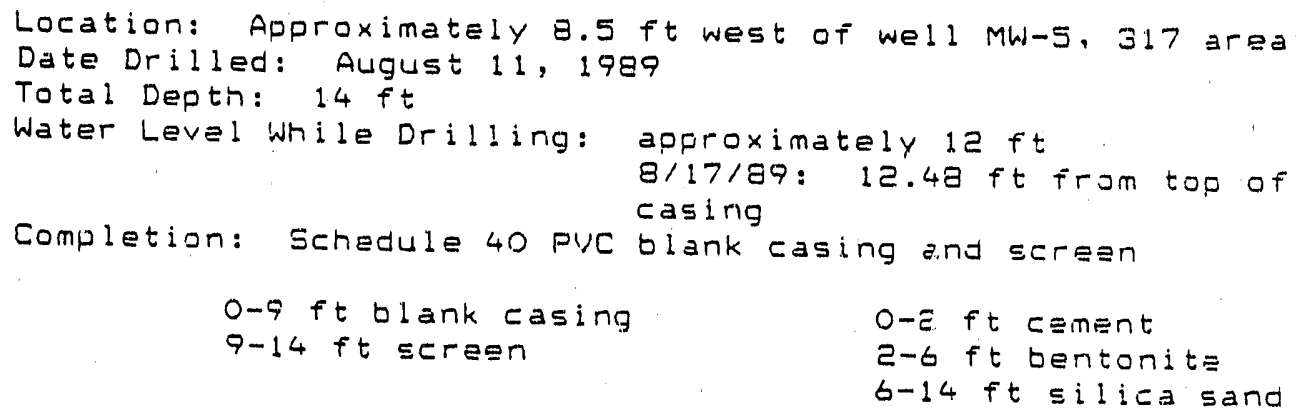

Geologist: T.L. Patton, ANL

Depth ( $T$ t) Description

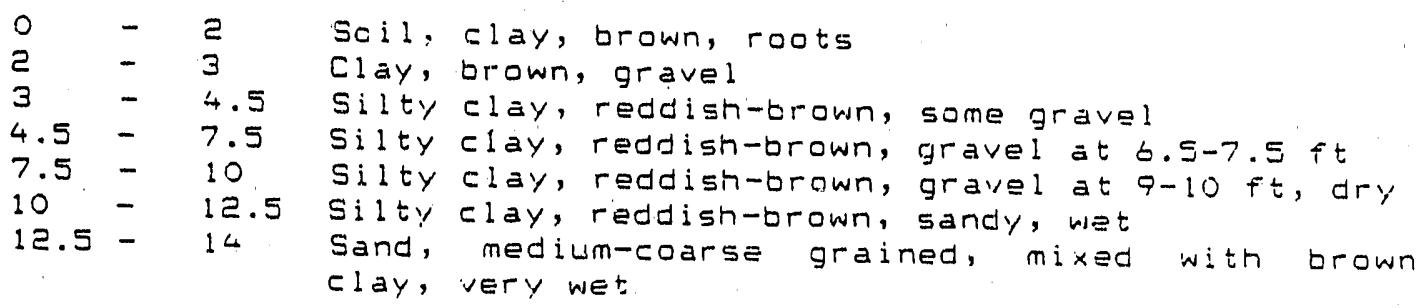




\section{REPLACEMENT WELL MW-5-25 (317 ArEa)}

Location: Approximately $3.5 \mathrm{ft}$ west of MW-5, 317 area Date Drilled: August 10,1989

Total. Depth: $25 \mathrm{ft}$

Water Level While Driling: $12.5 \mathrm{ft}$

Completion: Schedule 40 PVC threaded blank casing and screen

$$
\begin{aligned}
& 0-17 \text { ft blank casing } \\
& 17-22 \text { ft screen }
\end{aligned}
$$$$
0-2 \text { ft cement }
$$

old Casing: Casing filled with bentonite.

Geologist: T.L. Patton, ANL

\section{SOIL DESCRIPTION}

Location: Approximately $3.5 \mathrm{ft}$ west of well MW-5, 317 area Date Drilled: August 10,1989

Total Depth: $25 \mathrm{ft}$

Water Level While Drilling: Approximate"y $12.5 \mathrm{ft}$

8/17/89: DRY

Completion: Schedule 40 PVC blank casing and screen

$$
\begin{aligned}
& 0-17 \text { ft blank casing } \\
& 17-22 \text { ft screen }
\end{aligned}
$$

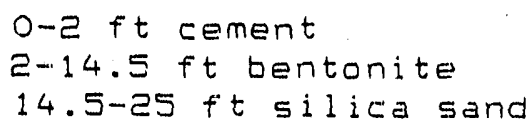

Geologist: T.L. Patton, ANL

Depth ( $f t$ ) Description

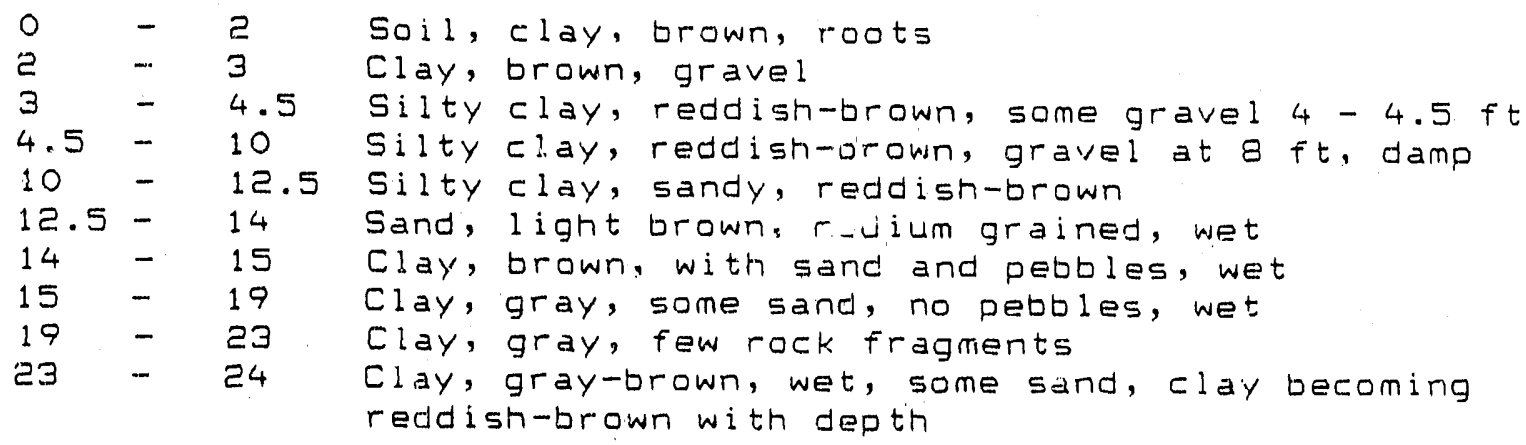




\section{$69 / 70$}

\section{Will County Well \& Pump Co., Inc. \\ PUMP SALES \& SERVICE \\ 1200 SOUTH CEDAR ROAD \\ NEW LENOX. ILLINOIS 6045I \\ (815) $485-2413 \quad$ (815) $727-2322$}

September 30,1988

Job \#3 (South of Radiation Waste Site) 317/319 Area

Total Depth of Well - 79'

Cased to $-70^{\prime}$ with one foot of casing above ground.

Water Level - Dry Hóle

Formations:

0 ' to $5^{\prime}$ Clay

$5^{\prime}$ to $20^{\prime}$ Sand \& Gravel

$20^{\prime}$ to $35^{\prime} \mathrm{Clay}$

$35^{\prime}$ to $69^{\prime}$ 'Sand \& Gravel

$69^{\prime}$ to $79^{\prime}$ ' Limestone

Job $\$ 4$ (S.E. of Radiation Waste Site by the Woods) $317 / 319$ Areq Total Depth of Well - 69'

Cased to $-60^{\prime}$ with one foot of cising above ground.

Water Leve1 - Dry Hole

Formations:

0 ' to 7 ' Surface \& Clay

7' to $20^{\prime}$ Sand \& Gravel

$20^{\prime}$ to $32^{\prime}$ Clay

$32^{\prime}$ to $59^{\prime}$ ' Sand \& Gravel

$59^{\prime}$ to $69^{\prime}$ 'Limestone 


\section{APPENDIX B: \\ STATIC WATER LEVELS MEASURED IN MONITORING WELLS SINCE 1986}

This appendix presents quarterly water level measurements for wells in the $317 / 319$ Area. Tables B.1, B.2, and B.3 give quarterly and annual average water levels for 1988,1987 , and 1986, respectively. They are based on information provided by ESH.

Table B.1 Well Point and Water Elevations of Monitoring Wells at the $317 / 319$ Area, 1988 (m above MSL)

\begin{tabular}{|c|c|c|c|c|c|c|c|}
\hline \multirow[b]{2}{*}{ Well } & \multirow{2}{*}{$\begin{array}{l}\text { Ground } \\
\text { Surface } \\
\text { Elevation }\end{array}$} & \multirow{2}{*}{$\begin{array}{l}\text { Well } \\
\text { Point } \\
\text { Elevation }\end{array}$} & \multicolumn{4}{|c|}{ Quarterly Elevationsa } & \multirow[b]{2}{*}{1988 Avg. } \\
\hline & & & $1 s t$ & $2 n d$ & $3 r d$ & 4 th & \\
\hline 1 & 209.81 & 197.38 & 201.78 & $200.76^{b}$ & 198.58 & 197.77 & 199.72 \\
\hline 2 & 209.17 & 197.34 & 202.05 & $201.53^{b}$ & 202.42 & 197.92 & 200.98 \\
\hline 3 & 204.28 & 192.11 & 193.32 & 194.06 & dry & dry & 193.69 \\
\hline 4 & 203.70 & 197.22 & dry & $d r y$ & dry & dry & - \\
\hline 5 & 208.32 & 197.35 & c & c & c & c & - \\
\hline 6 & 207.54 & 195.35 & 200.56 & 199.91 & 198.49 & 198.41 & 199.34 \\
\hline 7 & 207.57 & 188.73 & dry & dry & d & $d$ & - \\
\hline $10^{e}$ & 208.14 & 199.33 & - & - & 203.79 & 204.79 & 204.29 \\
\hline $11^{e}$ & 208.14 & 199.97 & - & - & 201.70 & 202.25 & 201.98 \\
\hline $12^{e}$ & 211.04 & 199.28 & - & - & 202.58 & 202.59 & 202.09 \\
\hline $13^{e}$ & 213.02 & 201.22 & - & - & 205.05 & 206.19 & 205.62 \\
\hline
\end{tabular}

Water-equivalent precipitation for the 30 - or 60-day periuds preceding the measurements was $93.0 \mathrm{~mm}$ for the $1 \mathrm{st}$ quarter, $21.2 \mathrm{~mm}$ for the $2 \mathrm{nd}, 59.2 \mathrm{~mm}$ for the $3 \mathrm{rd}$, and $125.0 \mathrm{~mm}$ for the $4 \mathrm{th}$. The $2 \mathrm{nd}$ - and $3 \mathrm{rd}$-quarter measurements are averages of two 30 -day periods.

$b_{V a l u e}$ is an average of two measurements made $5 / 17 / 88$ and $6 / 16 / 88$.

$\mathrm{c}_{\text {Well }}$ clogged at $6.4 \mathrm{~m}(2.1 \mathrm{ft})$.

${ }^{d}$ Not measured.

$e_{\text {We1 }} 10$ and 11 were installed $7 / 88$; wells 12 and 13 were installed $9 / 88$. 
TABLE B.2 Well Point and Water Elevations of Monitoring Wells at the 317/319 Area, 1987 (m above MSL)

\begin{tabular}{|c|c|c|c|c|c|c|c|}
\hline \multirow[b]{2}{*}{ Wel1 } & \multirow{2}{*}{$\begin{array}{l}\text { Ground } \\
\text { Surface } \\
\text { Elevation }\end{array}$} & \multirow{2}{*}{$\begin{array}{c}\text { Well. } \\
\text { Point } \\
\text { Elevation }\end{array}$} & \multicolumn{4}{|c|}{ Quarterly Elevations } & \multirow{2}{*}{1987 Avg. } \\
\hline & & & $1 \mathrm{st}$ & $2 n d$ & $3 \mathrm{rd}$ & $4 t h$ & \\
\hline 1. & 209.81 & 197.38 & $b$ & 201.52 & 199.66 & 199.06 & 200.08 \\
\hline 2 & 209.17 & 197.34 & $b$ & 201.87 & 200.89 & 200.09 & 200.95 \\
\hline 3 & 204.28 & 192.11 & $b$ & 193.33 & 193.32 & $d r y$ & 193.33 \\
\hline 4 & 203.70 & 197.22 & $\mathrm{~b}$ & dry & $d r y$ & $d r y$ & - \\
\hline $5^{c}$ & 208.32 & 197.35 & - & - & $\mathrm{d}$ & $d$ & - \\
\hline $6^{c}$ & 207.54 & 195.35 & - & - & 199.37 & 199.03 & 199.20 \\
\hline $7^{c}$ & 207.57 & 188.73 & - & - & $b$ & b. & - \\
\hline
\end{tabular}

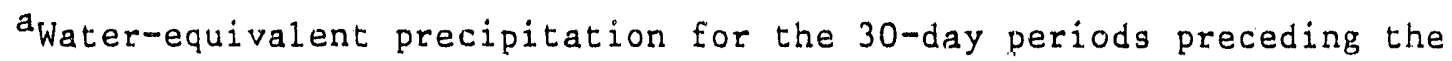
measurements was $59.4 \mathrm{~mm}$ for the $2 \mathrm{nd}$ quarter, $106.7 \mathrm{~mm}$ for the $3 \mathrm{rd}$, and $56.4 \mathrm{~mm}$ for the $4 \mathrm{th}$.

$b_{\text {Not measured. }}$

${ }^{C}$ Wells 5 and 6 were installed $8 / 87$; well 7 was installed $11 / 87$.

$\mathrm{d}_{\text {Well }}$ clogged at $6.4 \mathrm{~m}(21 \mathrm{ft})$. 


\section{$73 / 74$}

TABLE B.3 Well Point and Water Elevations of Monitoring Wells at the $317 / 319$ Area, 1986 (m above MSL)

\begin{tabular}{llcc}
\hline We11 & $\begin{array}{c}\text { Ground } \\
\text { Surface } \\
\text { Elevation }\end{array}$ & $\begin{array}{c}\text { Wel1 } \\
\text { Point } \\
\text { Elevation }\end{array}$ & $\begin{array}{c}\text { 4th-Quarter } \\
\text { Groundwater } \\
\text { Elevation }\end{array}$ \\
\hline 1 & 209.81 & 197.38 & $198.39^{\mathrm{c}}$ \\
2 & 209.17 & 197.34 & $199.82^{\mathrm{c}}$ \\
3 & 204.28 & 192.11 & dry \\
4 & 203.70 & 197.22 & dry \\
\hline
\end{tabular}

${ }^{a}$ All four wells were installed $9 / 86$.

Water-equivalent precipitation for the 60-day period preceding the measurements was $21.0 \mathrm{~mm}$. The value is an average of two 30-day periods.

${ }^{c}$ Value is an average of two measurements made $11 / 11 / 86$ and $12 / 22 / 86$. 


\section{APPENDIX C:}

\section{DRAFT GROUNDWATER MONITORING NETWORK GUIDANCE FROM THE ILLINOIS ENVIRONMENTAL PROTECTION AGENCY, DIVISION OF LAND POLLUTION CONTROL*}

The following outlines the general requirements for a groundwater monitoring network for an existing state-permitted facility. Facilities applying for horizontal expansions or for developmental permits are subject to Section 807.316 of Title 35: Subtitle G requirements and should refer to the Agency's Waste Management Facilities Design Criteria.

A. When proposing a groundwater monitoring network, the facility must be able to justify the proposed network by preparing a site-specific geological and hydrogeological report. The preparation of this report may necessitate a substantial amount of field work. This report must be prepared by a qualified geologist or geotechnical engineer and should include, at a minimum, the following:

1. A sufficient number of borings located in a manner that accurately represents the geological variations of the site. All test borings must be properly plugged and documented. Instructional information on test boring and monitoring well abandonment is included in the attachment [Table C.1]. Test borings should be continuously sampled and extend $30 \mathrm{ft}$ below the bottom of the maximum depth of the landfill invert and include where water was first encountered during the test boring, the water levels after the test boring was completed and allowed to stabilize for 24 hours, geologic descriptions of the units encountered, the surveyed land surface elevation, and the test boring location. Sieve analysis should be performed on samples from the units proposed for monitoring. This will aid in approximating permeability and porosity values and in determining a proper screen and gravel/sand pack size befole well installation. Textural classifications, particle size distribution curves, hydraulic conductivity, and lon-exchange capacities shall be determined for all unconsolidated material types present at the facility.

2. Cross sections depicting the stratigraphic relationships between the facility and the subsurface materials. The minimum number of cross sections at a site is two. The cross sections should intersect with the smallest angle of intersection of no less than $45^{\circ}$ and extend up to the borders of the site.

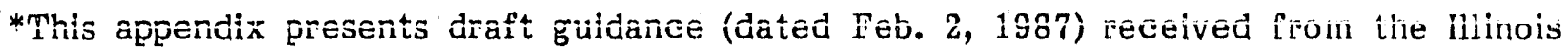
EPA. Except for reformatting and changes in punctuation and spelling, it is presented essentially as received. 

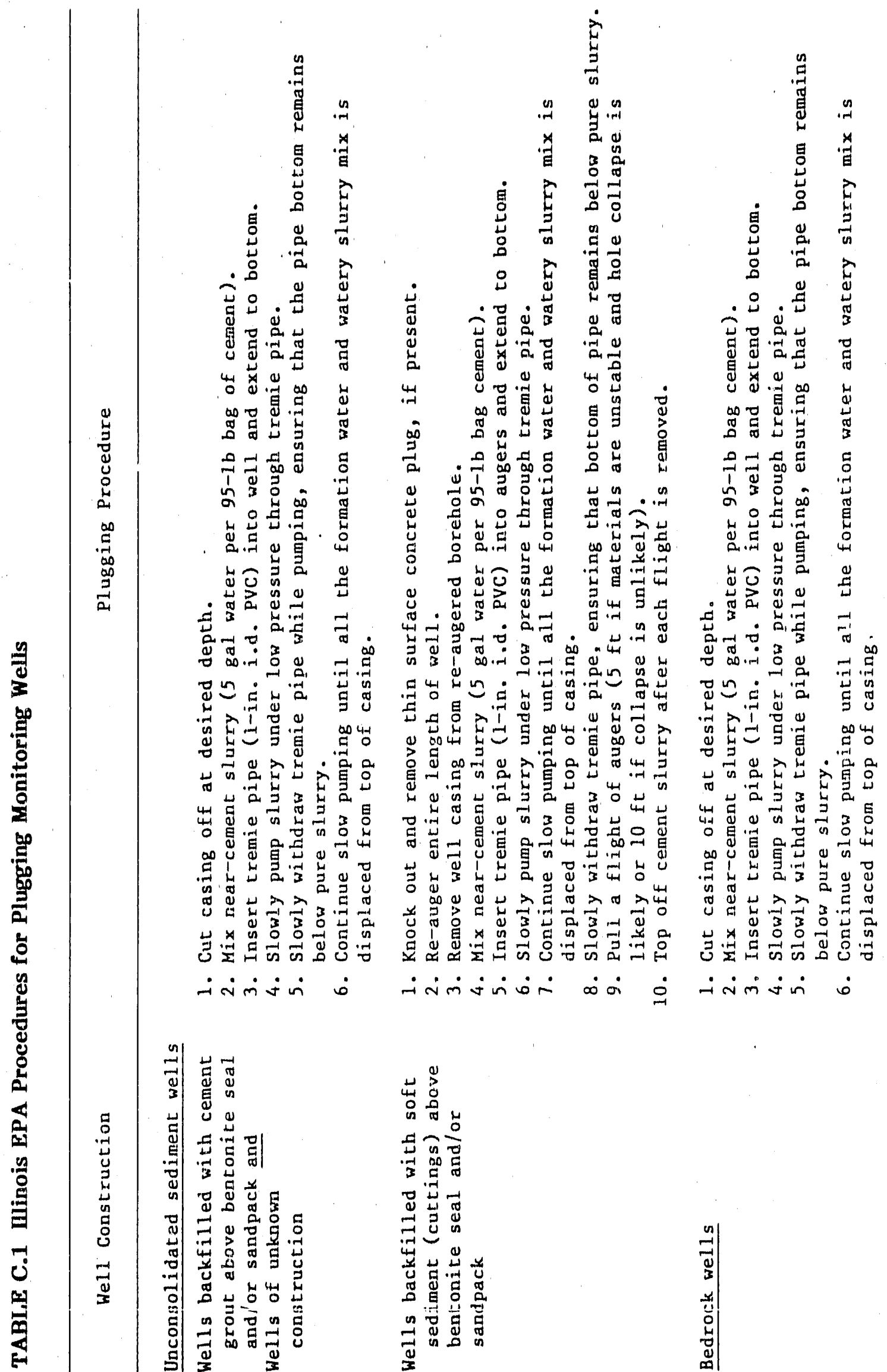
3. A detalled description of all water-bearing units presently used or potentlally usable as a source of water, Including depth to and the areal extent of the aquifer(s), direction of flow, and the Importance as a water supply.

4. A determination of groundwater fluctuations and aquifer characteristics, including flow directions, gradlents, and hydraulle conductivitles of water-bearing units benoath the site. In addition, seepage velocities of the groundwater through the aquifer(s) should be approximated based upon the preceding information.

5. Reglonal and local sources affecting groundwater flow at the site. Examples include recharge and depletion sources within one mlle, such as lagoons, lakes, and wells.

6. Present groundwater surface map of the site in the form of a groundwater plezometrio contour map. Datum should be referenced to mean sea level.

7. An assessment of the current groundwater quality at the site, including the facllity's impact on groundwater quality, if applicable.

B. The groundwater system shall include:

1. Monitoring well(s) that yield groundwater samples that best represent the quality of amblent groundwater unaffected by the monitored facllity.

2. Monitoring wells that yield groundwater samples that best represent the quality of groundwater passing bereath/through the facllity.

3. An assessment of the proposed groundwater monitoring network based upon the geologic and hydrogeologic report required for paragraph A above. The assessment shall demonstrate that the proposed number, locations, and screening intervals of the rnonitoring wells are adequate to show background water quality and "immediately" (during the next scheduled sampling event) detect any point source release in to the groundwaters of the state.

4. The above installed wells must be able to yleld groundwater samples of a significant quantlty for the completion of the required analyses within 24 hours after removirg the approprlate volumes of water in the well casing from the wells ( 1 to 3 volumes, depending upon well recharge). 
C. If a facillty contains more than one regulated unit (individually permitted areas), separate groundwater monitoring systems are not required. The only additional requirement is that the monitoring program should be able to determine which area is responsible for the potential contaminant release and determine the characteristios of such a release at the waste boundary(les).

\section{Monitoring well construction:}

1. The casing material(s) used must be such that it minimizes the well casing's effect on the analytical tests conducted on the water sample (any type of casing requiring solvent-cement type couplings may not be used). When organies are the contaminant of concern, the well casing material, as well as the well soreen material, must be stalnless steel (SS 316 or 304) or teflon. Thls casing must have an inside dlameter of not less than $2 \mathrm{in}$. or more than $4 \mathrm{ln}$.

2. The wall must be screened at an appropriate interval to include relatively permeable zones encountered. The well screen must be of a manufactured type and not less than $2 \mathrm{ft}$ or more than $10 \mathrm{ft}$ in length.

3. The annular space (1.e., the space between the bore hole and the well casing) along the screened section must be packed with sillea sand or gravel $2.5-3$ times larger than the $50 \%$ grain size of the zone being monitored. The top of the sand- or gravel-packed zone shall not extend past $2 \mathrm{ft}$ above or below the well sareen.

Note: In settings where the native materials are sand and gravel and will readily cave around the well screen, an artificial gravel pack may not be necessary.

4. The annular space above the screened section must be sealed with hydrated bentonite to prevent the contamination of samples and the groundwater. This seal must be properly located and be at least $2 \mathrm{ft}$ thick.

5. The annular space above the seal should be backfilled with expanding cement grout with $1 \%$ bentonite, by weight, added to the appropriate amount of water before being added to the cement or $5 \%$ bentonite, by volume, added to the cement before mixing with water.

6. All wells must be vented. The portion of the well casing extending above the ground surface must be protected to minimize damage or tampering. These precautions should include a protective casing with a locking cap and a concrete seal extending above the ground surface which is sloped away from the well casing so that surface water will be divorted away from the well casing and bore hole. The concrete cap shall extend clown below the frostlline (per diagram) [see Fig. C.1].

7. After the monitoring well has been constructed and aliowed to sit for 24 houris (this allows the coment grout to set properly before development), the well must be adequately developed 


\section{9}

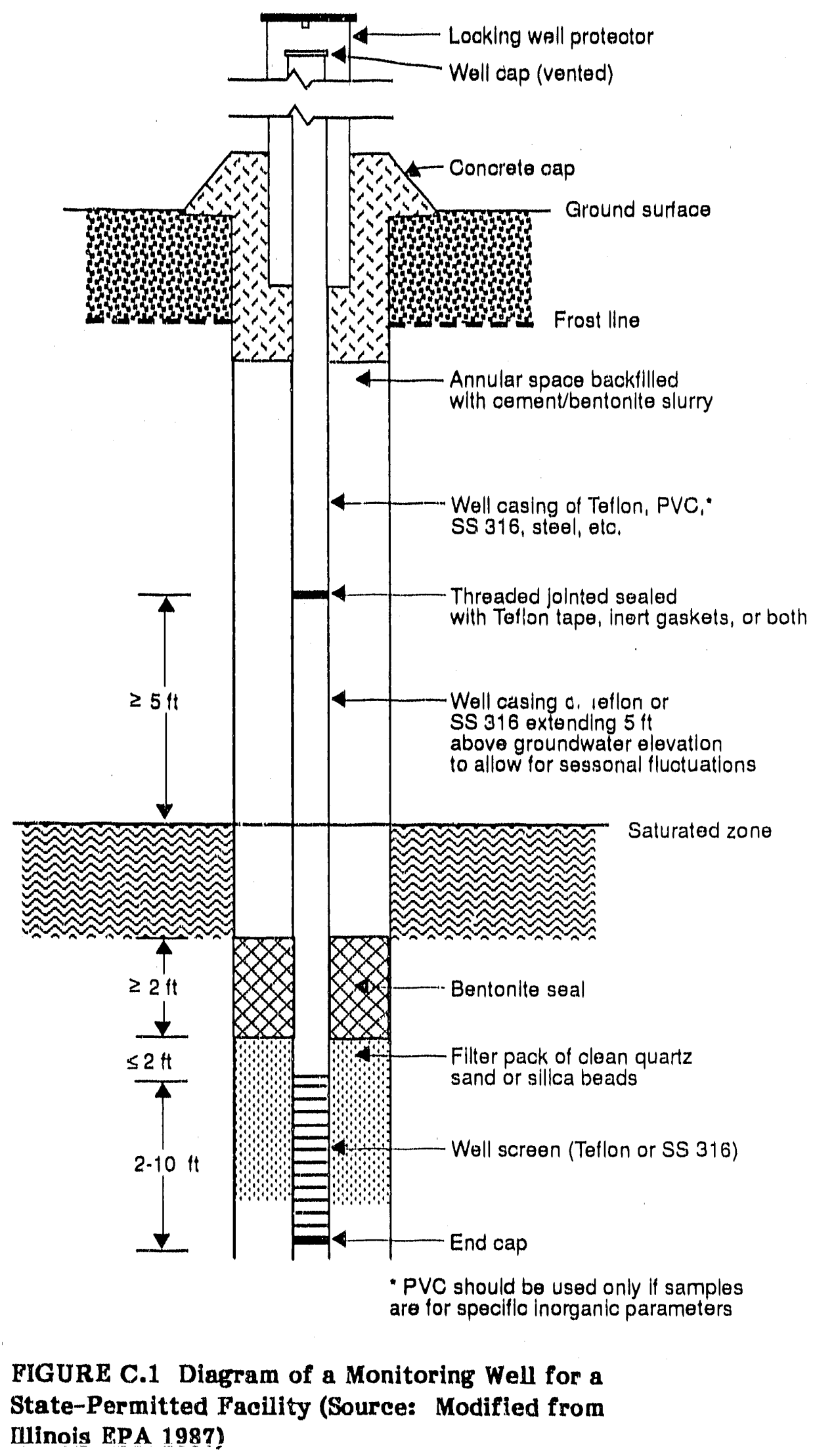


to minimize turbidlty within the well and increase flow Into the well. To establish proper groundwater sampling protocol, a test must be conducted at each monltoring well to determine hydraulle conductivity near the well. The test method (1.e., slug tests, pumping tests) used and results must be subritted to the Agency. This test should be conducted after the well is developed.

8. All monitoring wells must have boring logs and well completion (as built) diagrams that have been surveyed by a registered surveyor and reported to the Agenoy in MSL. [See Fig. C.2.] Also, all test borings should have the elevations surveyed and reported in MSL $( \pm 0.01 \mathrm{ft})$.

9. A scale drawing showing monitoring well and test boring locations. The drawing should also show bullding's, roads, the site's property boundaries, areas permitted for waste disposal, and currently fllled areas. In addition, a cartesian coordinate grid for the site should be established and shown on the map, and all test borings and monitoring wells should have coordinates surveyed and reported (l.e., establish a grid system).

E. Reports on the proposed groundwater monitoring program arid site hydrogeology should be prepared and submitted:

1. The proposed groundwater monitoring program and hydrogeologic report should be submitted to the Agency with a supplemental permit application.

2. The monitoring program must include quarterly sampling (four times a year) of the monitor wells. Four quarters (one year) of background (initial water quality) parameters are required for new monitoring points. When a monitoring well is being replaced, the replacement well may not be required to sample background parameters if the construction detalls of the old well are known and the new well is screened in the same stratigraphic unit and is installed next to the old well's previous location. If the replacement well does not meet the requirements that may exempt it from background parameter sampling, one quarter of background parameters may be adequate to establish initial groundwater quality for the well.

After background parameters (initial groundwater quality) for the monitoring wells have been established, the monitoring program should call for quarterly sampling of routine parameters. The Agency reserves the right to add additional parameters for routine or background sampling. The lists of routine and background parameters for groundwater monitoring are included in the attachment [see Table C.2]. 


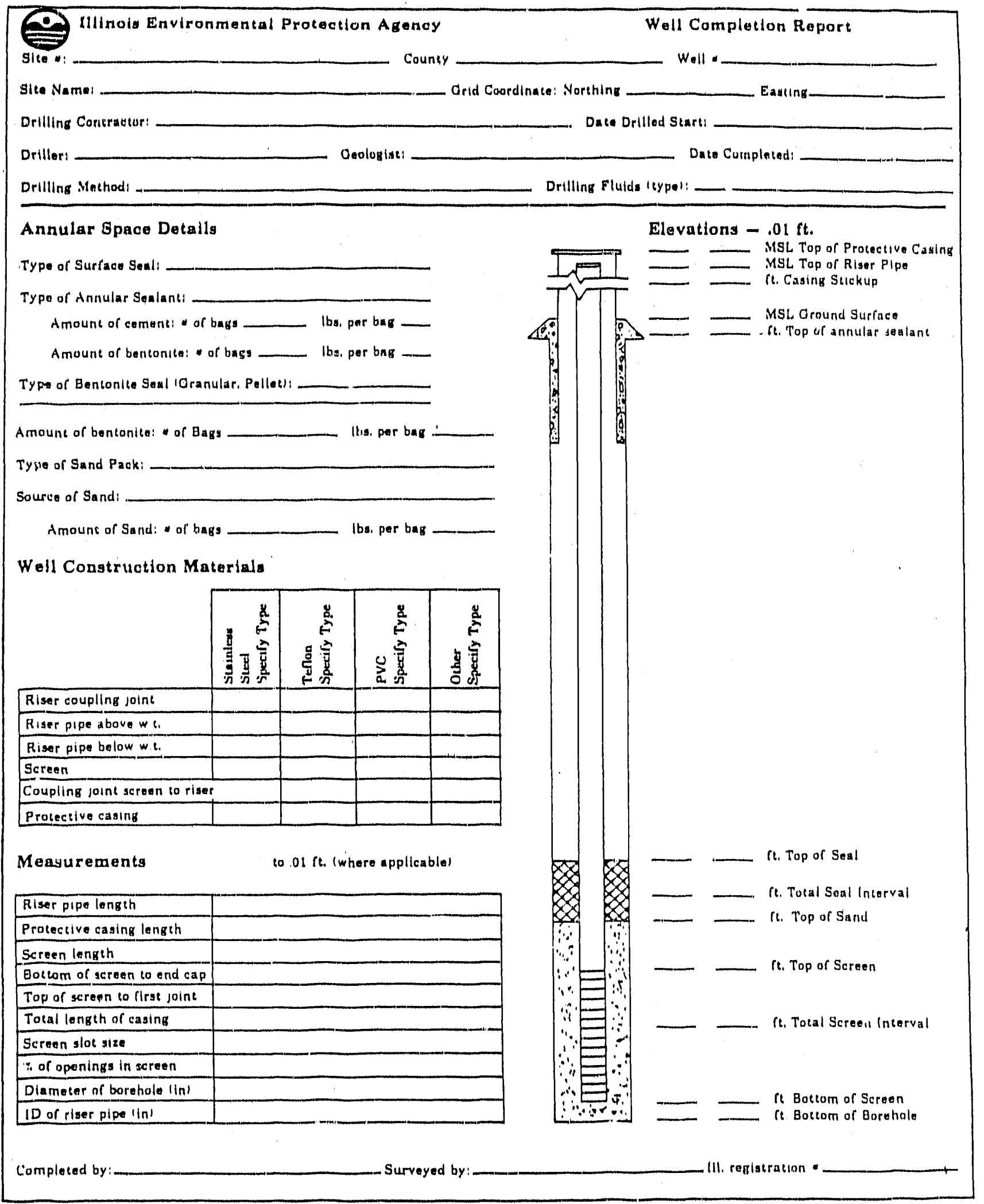


TABLE C.2 Routine and Background Analytic Parameters for Groundwater Monitoring in mlinois

Parameter Symbol Unit

\section{Routine}

Temperature of water sample, field-measured and unfiltered Specific conductance, fieldmeasured and unfiltered

$\mathrm{pH}$, field-measured and unfiltered

Elevation of groundwater surface Depth to water

Well depth elevation ${ }^{a}$

Depth to water

Alkalinity, total lab-measured

Total organic carbon

Chioride, dissolved

Sulfate, dissolved

Residue on evaporation at $180^{\circ} \mathrm{C}$

Background

$\begin{array}{ll}- & { }^{\circ} \mathrm{F} \\ \mathrm{SC} & \mu \mathrm{mho} \\ - & \text { standard unit } \\ - & \mathrm{ft} \text { above or below MSL } \\ - & \mathrm{ft} \text { below land surface } \\ - & \mathrm{ft} \text { above or below MSL } \\ - & \mathrm{ft} \mathrm{below} \mathrm{measuring} \mathrm{point} \\ - & \mathrm{mg} / \mathrm{L} \text { as CaCO } \\ \text { TOC } & \mathrm{mg} / \mathrm{L} \text { as carbon } \\ \mathrm{Cl} & \mathrm{mg} / \mathrm{L} \\ \mathrm{SO} & \mathrm{mg} / \mathrm{L} \\ \mathrm{ROE} & \mathrm{mg} / \mathrm{L}\end{array}$

$-\quad{ }^{\circ} \mathrm{F}$

SC $\quad \mu m h o$

- standard unit

- $\quad f t$ above or below MSL

- $\quad f t$ below land surface

- ft above or below MSL

- ft below measuring point

- $\quad \mathrm{mg} / \mathrm{L}$ as $\mathrm{CaCO}_{3}$

$\mathrm{NH}_{3}+\mathrm{NH}_{4} \mathrm{mg} / \mathrm{L}$ as itrogen

$\mathrm{N} \quad \mathrm{mg} / \mathrm{L}$

$\mathrm{P} \quad \mathrm{mg} / \mathrm{L}$

TOC $\mathrm{mg} / \mathrm{L}$ as carbon

$\mathrm{Cn} \quad \mathrm{mg} / \mathrm{L}$

$\mathrm{Ca} \quad \mathrm{mg} / \mathrm{L}$

$\mathrm{Mg} \quad \mathrm{mg} / \mathrm{L}$

$\mathrm{Na} \quad \mathrm{mg} / \mathrm{L}$

$\mathrm{K} \quad \mathrm{mg} / \mathrm{L}$

$\mathrm{Cl} \mathrm{mg} / \mathrm{L}$

$\mathrm{SO}_{4} \mathrm{mg} / \mathrm{L}$

F' $\mathrm{mg} / \mathrm{L}$

As $\mu g / L$

$\mathrm{Ba} \quad \mu \mathrm{g} / \mathrm{L}$ 


\section{$83 / 84$}

TABLE C.2 (Cont'd)

\begin{tabular}{|c|c|c|}
\hline Parameter & Symbol & Unit \\
\hline \multicolumn{3}{|l|}{ Background (cont'd) } \\
\hline $\begin{array}{l}\text { Boron, dissolved } \\
\text { Cadmium, dissolved } \\
\text { Chromium, dissolved } \\
\text { Iron, dissolved } \\
\text { Lead, dissolved } \\
\text { Manganese, dissolved } \\
\text { Nickel, dissolved } \\
\text { Silver, dissolved } \\
\text { Zinc, dissolved } \\
\text { Selenium, dissolved } \\
\text { Phenols, total unfiltered } \\
\text { Residue on evaporation at } 180^{\circ} \mathrm{C} \\
\text { Mercury, dissolved }\end{array}$ & $\begin{array}{l}\mathrm{B} \\
\mathrm{Cd} \\
\mathrm{Cr} \\
\mathrm{Fe} \\
\mathrm{Pb} \\
\mathrm{Mn} \\
\mathrm{Ni} \\
\mathrm{Ag} \\
\mathrm{Zn} \\
\mathrm{Se} \\
- \\
\mathrm{ROE} \\
\mathrm{Hg}\end{array}$ & $\begin{array}{l}\mu g / L \\
\mu g / L \\
\mu g / L \\
\mu g / L \\
\mu g / L \\
\mu g / L \\
\mu g / L \\
\mu g / L \\
\mu g / L \\
\mu g / L \\
\mu g / L \\
\mathrm{mg} / L \\
\mu g / L\end{array}$ \\
\hline
\end{tabular}

${ }^{a}$ Should be reported annually.

Source: Illinois EPA 1987. 


\section{APPENDIX D:}

\section{MONITORING WELL DESIGN AND CONSTRUCTION RECOMMENDATIONS OF THE U.S. ENVIRONMENTAL PROTECTION AGENCY}

In this time of environmental awareness, appropriate design and construction of environmental monitoring wells is critical. If the wells do not meet accepted regulatory standards, data obtained from them may be declared invalid by a regulatory agency. To avoid this possibility, all monitoring wells installed at ANL should meet minimum regulatory requirements. The following summary of monitoring well design and construction protocol is based on U.S. EPA (1989) recommendations and meets both federal and state of Illinois regulatory requirements.

\section{D.1 DRILLING METHODS}

A number of methods can be used to drill and install groundwater monitoring wells. The method employed should be selected to minimize the disturbance of subsurface materials and avoid inadvertent contamination of the subsurface and groundwater. The five most commonly used methods for drilling and installing groundwater monitoring wells are: (1) air rotary, (2) water rotary, (3) cable tool, (4) hollow-stem continuous auger, and (5) solid-stem continuous flight auger. Each of these drilling methods has its advantages and disadvantages. Hollow-stem augers are preferable for drilling shallow monitoring wells at ANL because they allow collection of geologic cores from known depths. Solid-stem augers are a distant second choice.

Hollow-stem augers are most commonly used for construction of monitoring wells in unconsolidated materials less than $150 \mathrm{ft}$ thick. This method does not require the use of drilling fluids (muds), which can plug up silty formations and affect water sample analyses. Drilling fluids can also increase the disturbance of the geologic material penetrated during drilling. The maximum diameter of a well that can be constructed with a hollow-stem auger drill is 4 in.

Normal well drilling practices call for the well to be drilled to its designated depth, which usually is the first permeable water-bearing zone encountered. The drilling equipment is then removed from the well bore, and the well is completed by installing the screen, blank casing, gravel filter pack, and annular sealant. The we!l should be completed at a depth sufficient to allow for seasonal water-table fluctuations. In formations where the borehole will stand open, the well is completed after the auger flights are removed from the borehole. In formations where the borehole will not stand open, the well is completed inside the hollow-stem auger prior to its removal from the ground.

The well completion method of ten depends on the subsurface gieologic conditions and the amount of groundwater encountered. In some cases, a well bore can stay open, especially when drilled in heavy clay soils where only a limited amount of groundwater is encountered. However, when the clay becornes wet, it may collapse into the well bore, causing the hole to close as soon as the augers are removed. 
A monitoring well is only as good as its completion. Therefore the driller must be sure that the well is completed according to specifications. Precautions have to be taken so as not to adversely affect the integrity of the well when it is being constructed, especially when constructing the well inside the hollow-stem auger. If precautions are not taken, the screen may accidentally be pulled up from its designated depth when the auger flights are removed. If for this or any other reason the construction of the well is suspected of being inadequate, the screen and casing will have to be reinstalled. This may mean pulling and reinstalling the casing or redrilling the well and installing the casing.

\section{D.2 WELL CASING AND SCREEN}

A variety of construction materials are available for the casing and well screen, including polytetrafluorethylene (teflon), steel (stainless, black, or galvanized), polyvinyl chloride (PVC), polyethylene, epoxy biphenol, and polypropylene. Some of these materials may affect the quality of groundwater samples. In addition, some may not have the long-term structural characteristics required for monitoring wells. For example, steel casing deteriorates in corrosive environments; PVC deteriorates when in contact with ketones, esters, and aromatic hydrocarbons; and polyethylene deteriorates in contact with oxidizing acids, aliphatic hydrocarbons, and aromatic hydrocarbons. Studies have shown that deterioration of the screen and casing material may affect the quality of groundwater samples collected. Therefore, it is very important that the casing and screen are constructed of material compatible with suspected chemicals in the groundwater.

The U.S. EPA (1989) recommends that the monitoring well screen and thos? portions of the well casing in the saturated zone be constructed of materials that have proven chemically and physically stable, such as tefion and stainless steel 316 . Other noninert material, such as steel, PVC, polyethylene, and polypropylene, may be used for casing the well above the saturated zone.

The plastic pipe sections must be flush threaded or have the ability to be connected by another method that will not introduce contaminants such as glue or solvents into the well.

Normally, eith 2 - or 4-in.-interior-diameter well casing is used in monitoring well construction. Larger casing diameters may be necessary where purging or sampling equipment is used or where the well is completed in a deep formation. Upon completion, the casing should extend from 1 to $3 \mathrm{ft}$ above the surface of the ground.

The size of the well screen must be adequate to allow sufficient quantities of groundwater to flow into the well for sampling. It should be designed so as to minimize the passage of formation materials (turbidity) into the well, and it should have sufficient structural integrity to prevent the collapse of the screen.

For wells constructed in unconsolidated material, the intake of the monitoring well should consist of a screen or slotted casing with openings sized to ensure that the surrounding geological material does not enter the well during development. 
Commercially manufactured screens and slotted casing should be used. Screens should not be slotted in the field. If the nature and particle size of the aquifer material is not known before the drilling takes place, several sizes of slotted well screens should be on site to ensure that the correct screen can be placed in the well.

At ANL, most of the shallow monitoring wells will be completed in silts and clays. Therefore, a No. 10 screen size should be used.

The U.S. EPA does not make any recommendations regarding well-screen length except that it should depend on the variability of the subsurface formations and the contaminant being monitored. Highly variable formations require a shorter well screen, which allows sampling of discrete portions of the formation. Certain hydrogeological settings -- for example, widely fluctuating water levels -- necessitate the use of longer well screens. Formations with low hydraulic conductivities may also necessitate the use of longer well screens to allow sufficient amounts of formation water to enter the well for sumpling. Normally, well screens no longer than 5-10 ft are installed.

The chemical processes of dispersion and sorption greatly influence the potential contaminant migration pathways within an aquifer. To monitor for heavy metals, the screened interval should be just above the confining layer. For monitoring of light organics or hydrocarbons, the screened interval should be at the water-table/capillaryzone interface.

\section{D.3 FILTER PACK AND ANNULAR SEALANT}

To improve the performance of the monitoring well, the geological material immediately around the well screen is removed and replaced by a chemically inert, wellrounded, and dimensionally stable filter pack, such as clean quartz sand, silica, or glass beads. The filter pack must be sized to prevent most of the surrounding geological material from entering the well screen. The size of the screen opening is in turn selected to prevent about $90 \%$ of the filter pack from entering the well casing after development. Material used should be 2.5-3 times larger than 50\% of the grain size of the zone being monitored. The U.S. EPA also recommends that the filter pack not extend more than $2 \mathrm{ft}$ above the top or below the bottom of the base of the well screen.

Filter packing is especially advantageous when (1) the sediments are highly uniform and fine-grained or are highly laminated or (2) all the materials to be used in the well construction must be on site before drilling begins.

To prevent the migration of contaminants from the surface or intermediate zones to the sampling zone or prevent cross contamination between strata, the materials used to seal the well bore above the filter pack must be chemically resistant to ensure seal integrity during the life of the monitoring well. These maierials should also be chemically inert so as not to affect the quality of the groundwater samples.

Proper construction of the annular sealant is very important. At a minimum, $2 \mathrm{ft}$ of certified coarse-grit sodium bentonite should immediately overlie the filter pack. Where the saturated zone extends above the well screen, only certified coarse-grit 
sodium bentonite should be used. Above the bentonite seal, a cement and bentonite mixture, bontonite chips or pellets, or antishrink cement mixture should be used as the annular sesiantextending into the unsaturated zone to a point just below the frost line. A cap of concrete should extend above the frost line and blend into a cement apron that slopes away from the outer edge of the borehole.

The untreated sodium bentonite seal should be placed around the casing either by dropping it directly down the borehole, or, if a hollow-stem auger is used, putting the bentonite between the casing and the inside of the auger stem. Both of these methods present a potential for bridging (the creation of air bubbles that prevent the formation of a tight seal). In shallow monitoring wells, a tamping device should be used to reduce this potential. In deeper wells it may be necessary to pour a small amount of formation water down the casing to wash the bentonite down the hole.

The cement-bentonite grout should be prepared using formation water and placed in the borehole using a tremie pipe. The cement-bentonite grout should extend to the base of the frost zone. The treinle method ensures a good seal for the borehole from the bottom. The cement-bentonite grout should be prepared using a mechanical mixing device.

The remainder of the well bore should be filled with a cement slurry. A cement collar, at least $2-\mathrm{ft}$ in radius and sloping away from the casing, should be emplaced around the casing.

\section{D.4 PROTECTIVE CASING}

A steel protective casing should be installed around the well casing about $3 \mathrm{ft}$ down in to the grout and cement mixture and should extend about $3 \mathrm{ft}$ above the ground surface. The aboveground portions of both the well casing and the protective casing should be vented. The aboveground portion of the protective casing should be painted a bright color, clearly marked, and equipped with a padlock.

Two steel posts or railroad ties should be placed in the ground around the well. These posts should extend a minimum of $4 \mathrm{ft}$ above ground surface to protect the well from damage (e.g., if it were struck by a vehicle).

\section{D.5 WELL DEVELOPMENT}

After the well is constructed, it should be developed to remove fine particles to allow freer entry of water into the well. A variety of techniques are available to accomplish this. When flow is continuous in one direction, bridging of particles is common. To be effective, these techniques require reversals or surges in flow to avoid bridging by particles. Reversals and surges can be created by using surge blocks, bailers, or pumps. Formation water should be used for surging the well. It may be necessary to use añ outside source of water when devcloping a low-yielding water-bearing formation. This water should be chemically analyzed to evaluate its potential impact on the in-situ water quality. The driller should not use air to develop the well. 
A sufficient number of well volumes of water should be evacuated to ensure that the samples collected represent ambient conditions. If water is removed during the development process, it should be discharged at a point downgradient to all sampling points. Water levels should be measured after completion of well development and as many times as is necessary thereafter to determine the static water level in each well. All water level measurements should be documented. A well completion report (Fig. C.2) should be made to include such pertinent information as well construction materials, elevation of the protective casing and ground surface, annular sealant and filter pack material, position of the well screen, and any other measurements.

The elevation (above MSL) of the monitoring well casing should be surveyed by a licensed professional surveyor to an accuracy of $\pm 0.01 \mathrm{ft}$. Spatial locations should be surveyed to an accuracy of $\pm 1.0 \mathrm{ft}$. The designations of the well and the point on the casing from which its elevation was determined should be clearly marked on each casing.

\section{D.6 QUALITY ASSURANCE/QUALITY CONTROL}

To avoid introducing contamination into the subsurface or groundwater, it is important that the drilling equipment be steam-cleaned before each use and between borehole locations. The casing and screen should be steam-cleaned prior to emplacement to ensure that all oils, grease, and waxes have been removed. 

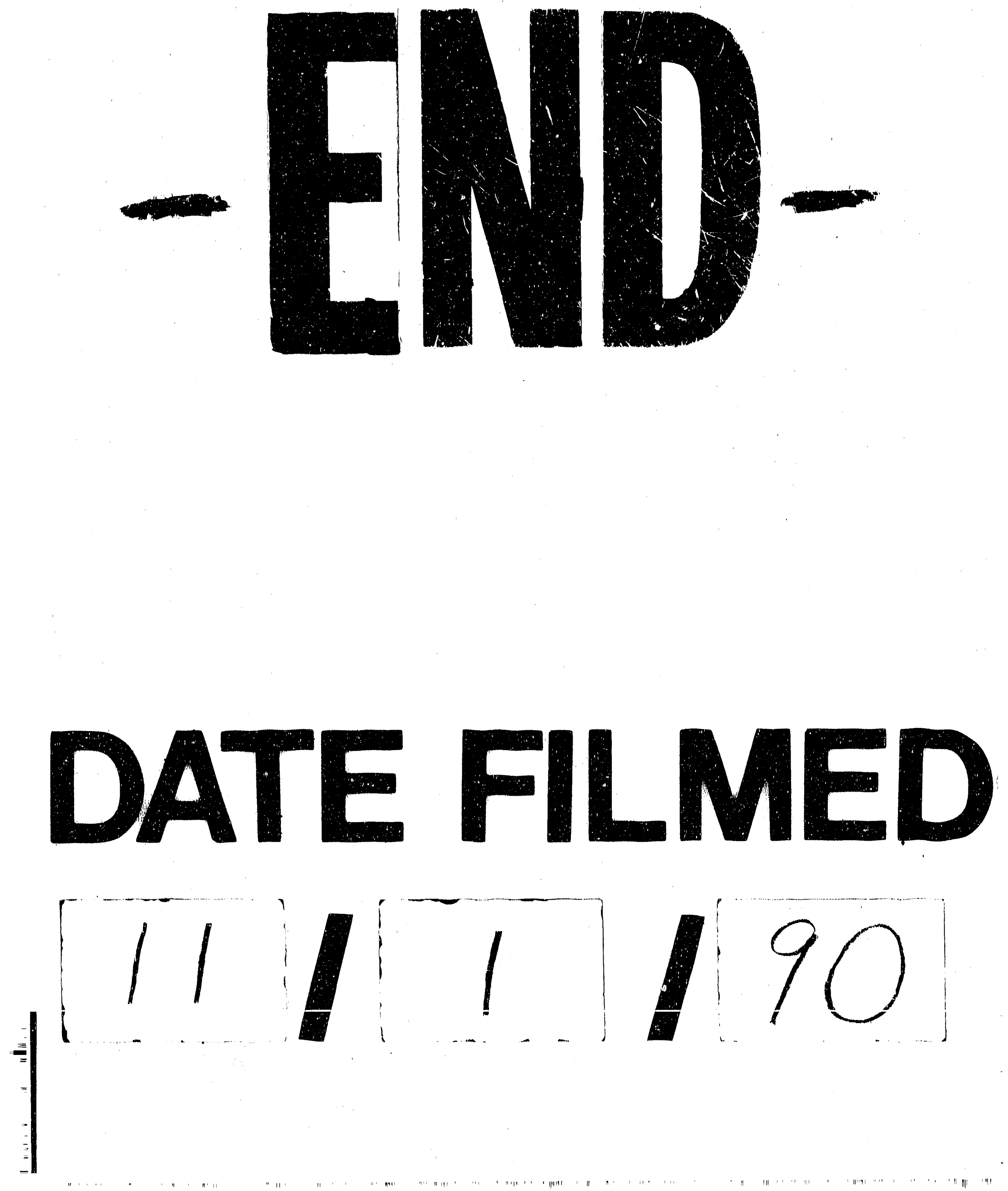
